Prepared in cooperation with the Office of Hawaiian Affairs, State of Hawai'i

\title{
Water Use in Wetland Kalo Cultivation in Hawai'i
}

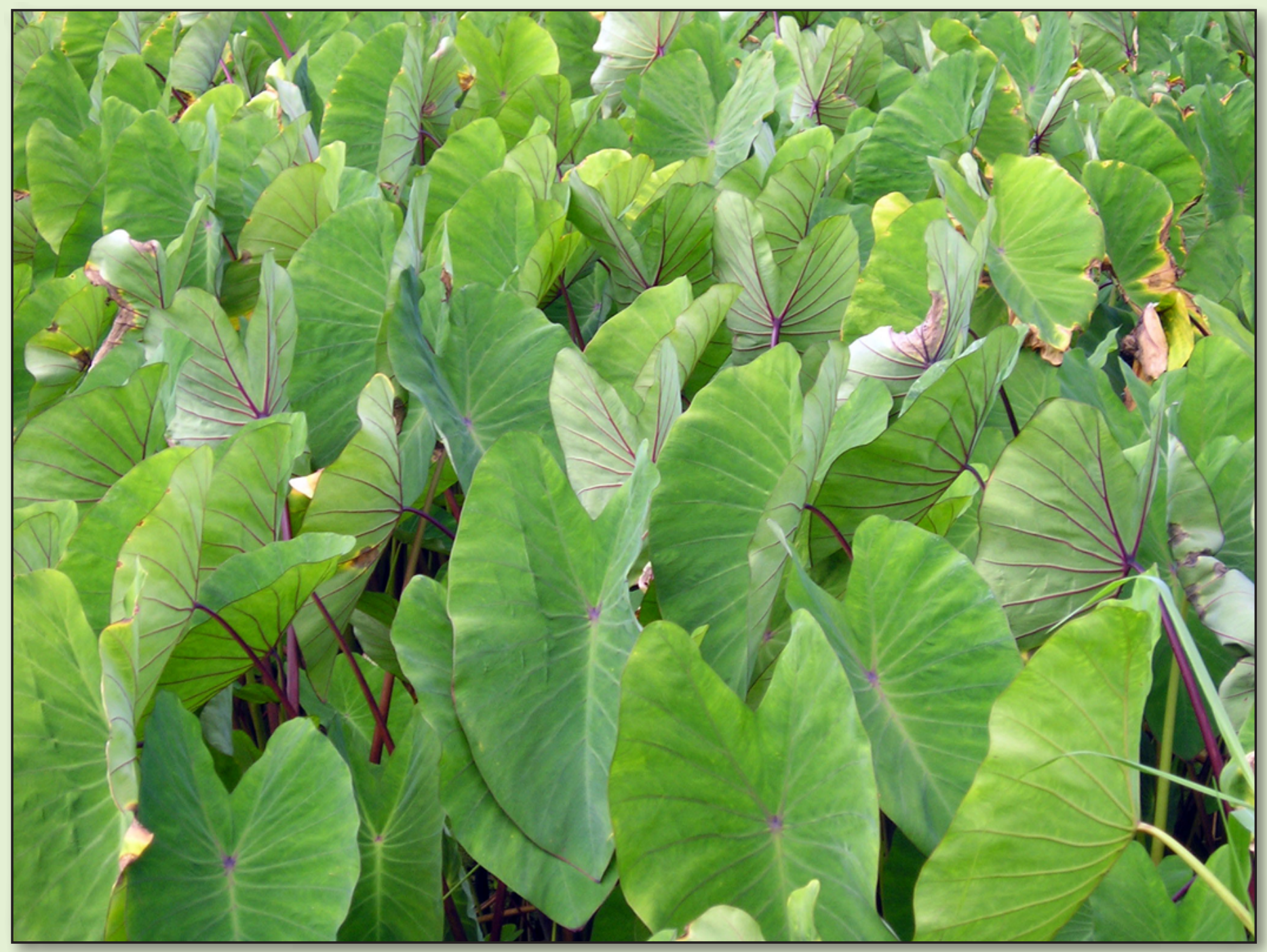

Open-File Report 2007-1157 
COVER

Kalo or taro (Colocasia esculenta (L.) Schott) typically in Hawai'i is grown in wetland patches (lo 'i) directly irrigated with water from rivers or streams. Nearly 300 forms of Hawaiian kalo have been recorded. As a food source it was so important that it was referred to simply as 'ai, which means food in Hawaiian. Practically the entire plant is edible.

Photo by Chiu W. Yeung, U.S. Geological Survey. 


\section{Water Use in Wetland Kalo Cultivation in Hawai' $i$}

By Stephen B. Gingerich, Chiu W. Yeung, Tracy-Joy N. Ibarra, and John A. Engott

Prepared in cooperation with the Office of Hawaiian Affairs, State of Hawai' $i$

Open-File Report 2007-1157 


\title{
U.S. Department of the Interior DIRK KEMPTHORNE, Secretary
}

\author{
U.S. Geological Survey \\ Mark D. Myers, Director
}

U.S. Geological Survey, Reston, Virginia: 2007

For product and ordering information:

World Wide Web: http://www.usgs.gov/pubprod

Telephone: 1-888-ASK-USGS

For more information on the USGS--the Federal source for science about the Earth, its natural and living resources, natural hazards, and the environment:

World Wide Web: http://www.usgs.gov

Telephone: 1-888-ASK-USGS

Any use of trade, product, or firm names is for descriptive purposes only and does not imply endorsement by the U.S. Government.

Although this report is in the public domain, permission must be secured from the individual copyright owners to reproduce any copyrighted materials contained within this report.

Suggested citation:

Gingerich, S.B., Yeung, C.W., Ibarra, T.N., and Engott, J.A., 2007, Water use in wetland kalo cultivation in Hawai'i: U.S. Geological Survey Open-File Report 2007-1157, 68 p. 


\section{Contents}

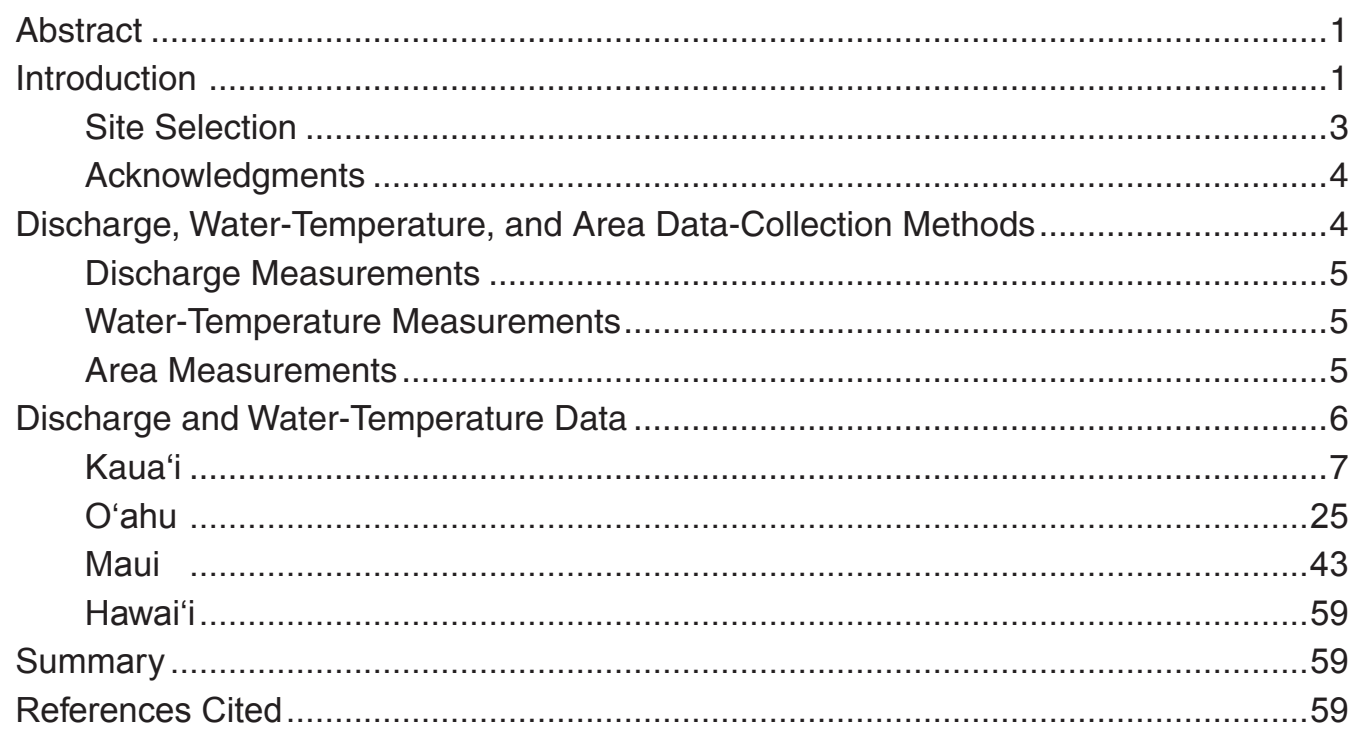

\section{Figures}

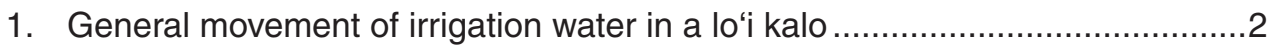

2. Location of significant areas of kalo cultivation, State of Hawai'i.....................4

3. Flow measured by U.S. Geological Survey staff in lo'i kalo 'auwai with (A) an acoustic Doppler velocimeter and $(B)$ the volumetric method.....................5

4. Thermistor and PVC housing used for collecting temperature

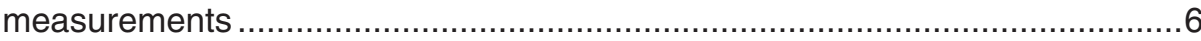

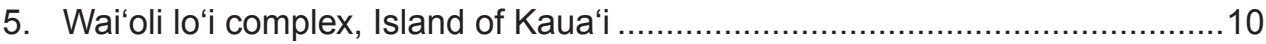

6. Water temperature in Wai'oli lo'i complex, Island of Kaua'i.............................11

7. Daily pattern of water temperature in Wai'oli lo'i complex,

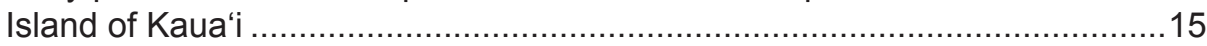

8. Hanalei lo'i complex, Island of Kaua'i .......................................................19

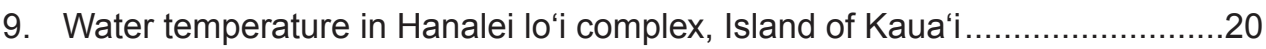

10. Daily pattern of water temperature in Hanalei lo'i complex,

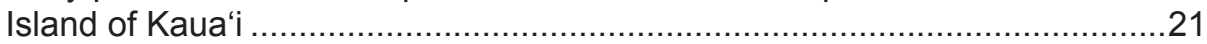

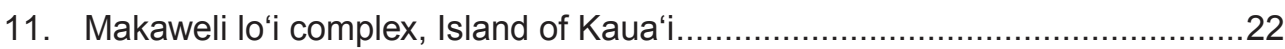

12. Water temperature in Makaweli lo'i complex, Island of Kaua'i ........................23

13. Daily pattern of water temperature in Makaweli lo'i complex, Island of Kaua'i 


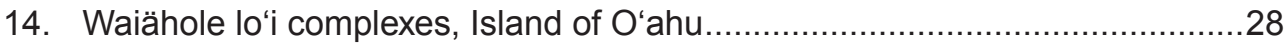

15. Water temperature in Waiähole lo'i complexes, Island of O'ahu ....................29

16. Daily pattern of water temperature in Waiähole lo'i complexes, Island of

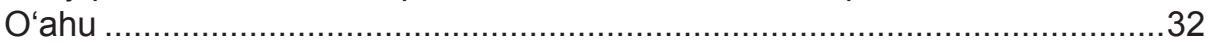

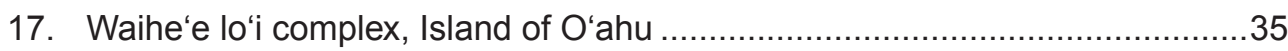

18. Water temperature in Waihe'e lo'i complexes, Island of O'ahu .......................36

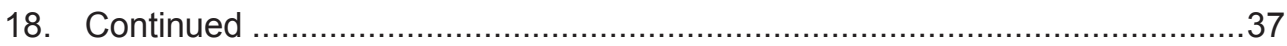

19. Daily pattern of water temperature in Waihe'e lo'i complex,

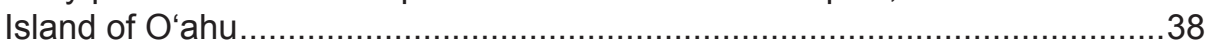

20. Hale'iwa lo'i complex, Island of O'ahu .................................................... 40

21. Water temperature in Hale'iwa lo'i complexes, Island of O'ahu .....................41

22. Daily pattern of water temperature in Hale'iwa lo'i complex, Island of O’ahu . .42

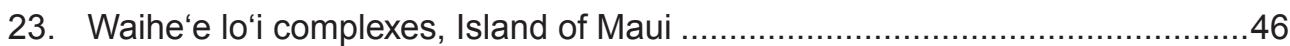

24. Water temperature in Waihe'e lo'i complexes, Island of Maui .........................47

25. Daily pattern of water temperature in Waihe'e lo'i complexes, Island of

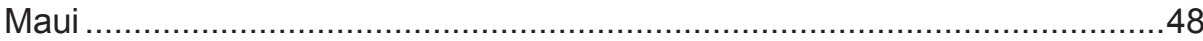

26. Wailua (Lakini) lo'i complex, Island of Maui ..............................................49

27. Water temperature in Wailua (Lakini) lo'i complex, Island of Maui..................50

28. Daily pattern of water temperature in Wailua (Lakini) lo'i complex, Island of Maui .....

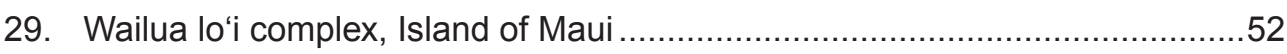

30. Water temperature in Wailua lo'i complex, Island of Maui.............................53

31. Daily pattern of water temperature in Wailua lo'i complex, Island of Maui......53

32. Wailua (Waikani) lo'i complex, Island of Maui ..............................................54

33. Water temperature in Wailua (Waikani) lo'i complex, Island of Maui...............55

34. Daily pattern of water temperature in Wailua (Waikani) lo'i complex, Island

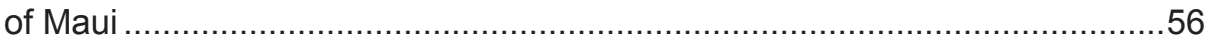

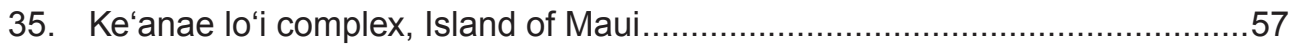

36. Water temperature in Ke'anae lo'i complex, Island of Maui ..........................58

37. Daily pattern of water temperature in Ke'anae lo'i complex, Island of Maui....58

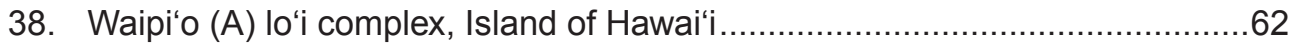

39. Waipi'o (B) lo'i complex, Island of Hawai'i.................................................63

40. Water temperature in Waipi'o (A) lo'i complex, Island of Hawai'i ....................64

41. Daily pattern of water temperature in Waipi'o (A) lo'i complex, Island of

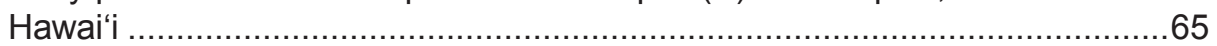

42. Water temperature in Waipi'o (B) lo'i complex, Island of Hawai'i ...................66

43. Daily pattern of water temperature in Waipi'o (B) lo'i complex, Island of Hawai'i 


\section{Tables}

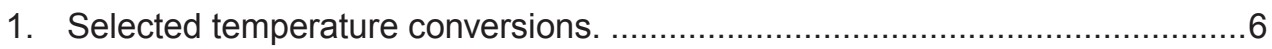

2. Summary of discharge measurements and areas for selected lo'i complexes, Island of Kaua'i .....

3. Water-temperature statistics based on measurements collected at 15-minute intervals for lo'i complexes on the Island of Kaua' $i$

4. Summary of discharge measurements and areas for selected lo' $\mathrm{i}$

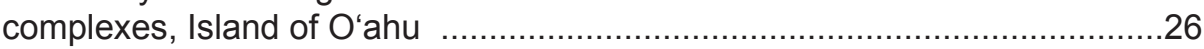

5. Water-temperature statistics based on measurements collected at 15-minute intervals for lo'i complexes on the Island of O'ahu ........................27

6. Summary of discharge measurements and areas for selected lo'i complexes, Island of Maui.....

7. Water-temperature statistics based on measurements collected at 15-minute intervals for lo'i complexes on the Island of Maui.

8. Summary of discharge measurements and areas for selected lo' $\mathrm{i}$ complexes, Island of Hawai'i.....

9. Water-temperature statistics based on measurements collected at 15-minute intervals for lo'i complexes on the Island of Hawai' $i$.

10. Summary of water use calculated for lo'i and lo'i complexes by island, State of Hawai'i..... 


\section{Conversion Factors}

\begin{tabular}{|c|c|c|}
\hline Multiply & By & To obtain \\
\hline \multicolumn{3}{|c|}{ Area } \\
\hline acre & 4,047 & square meter $\left(\mathrm{m}^{2}\right)$ \\
\hline \multicolumn{3}{|c|}{ Volume } \\
\hline million gallons (Mgal) & 3,785 & cubic meter $\left(\mathrm{m}^{3}\right)$ \\
\hline \multicolumn{3}{|c|}{ Flow rate } \\
\hline million gallons per day (Mgal/d) & 0.04381 & cubic meter per second $\left(\mathrm{m}^{3} / \mathrm{s}\right)$ \\
\hline
\end{tabular}

Temperature in degrees Celsius $\left({ }^{\circ} \mathrm{C}\right)$ may be converted to degrees Fahrenheit $\left({ }^{\circ} \mathrm{F}\right)$ as follows:

${ }^{\circ} \mathrm{F}=(1.8 \times \mathrm{C})+32$

Temperature in degrees Fahrenheit $\left({ }^{\circ} \mathrm{F}\right)$ may be converted to degrees Celsius $\left({ }^{\circ} \mathrm{C}\right)$ as follows:

${ }^{\circ} \mathrm{C}=\left({ }^{\circ} \mathrm{F}-32\right) / 1.8$

Vertical coordinate information is referenced to mean sea level.

Horizontal coordinate information is referenced to the North American Datum of 1983 (NAD 83). 


\title{
Water Use in Wetland Kalo Cultivation in Hawai'i
}

\author{
By Stephen B. Gingerich, Chiu W. Yeung, Tracy-Joy N. Ibarra, and John A. Engott
}

\section{Abstract}

Ten cultivation areas ( 8 windward, 2 leeward) were selected for a kalo water-use study, primarily on the basis of the diversity of environmental and agricultural conditions under which wetland kalo is grown and landowner permission and availability. Flow and water-temperature data were collected at the lo"i complex level and at the individual lo' $\mathrm{i}$ level. To ensure that flow and temperature data collected at different lo 'i reflect similar irrigation conditions (continuous flooding of the mature crop), only lo $i$ with crops near the harvesting stage were selected for water-temperature data collection. The water need for kalo cultivation varies depending on the crop stage. In this study, data were collected during the dry season (June - October), when water requirements for cooling kalo approach upper limits. Flow measurements generally were made during the warmest part of the day, and temperature measurements were made every 15 minutes at each site for about a 2-month period.

Flow and temperature data were collected from kalo cultivation areas on four islands-Kaua' $i$, O'ahu, Maui, and Hawai'i. The average inflow value for the 19 lo' $i$ complexes measured in this study is 260,000 gallons per acre per day, and the median inflow value is 150,000 gallons per acre per day. The average inflow value for the 17 windward sites is 270,000 gallons per acre per day, and the median inflow value is 150,000 gallons per acre per day. The average inflow value for the two leeward sites is 150,000 gallons per acre per day. The average inflow value measured for six individual lo ' $\mathrm{i}$ is 350,000 gallons per acre per day, and the median inflow value is 270,000 gallons per acre per day. The average inflow value for the five windward lo ' $\mathrm{i}$ is 370,000 gallons per acre per day, and the median inflow value is 320,000 gallons per acre per day. The inflow value for the one leeward lo ' $i$ is 210,000 gallons per acre per day. These inflow values are consistent with previously reported values for inflow and are significantly higher than values generally estimated for water consumption during kalo cultivation. These measurements of inflow are important for future considerations of water-use requirements for successful kalo cultivation.

Of the 17 lo' $i$ complexes where water inflow temperature was measured, only 3 had inflow temperatures that rose above $27^{\circ} \mathrm{C}$, the threshold temperature above which wetland kalo is more susceptible to fungi and associated rotting diseases. The coldest mean inflow temperature was $20.0^{\circ} \mathrm{C}$ and the warmest inflow temperature was $24.9^{\circ} \mathrm{C}$. All 15 of the sites where outflow temperatures were measured had some temperatures greater than $27^{\circ} \mathrm{C}$. Outflow temperatures exceeded $27^{\circ} \mathrm{C}$ between 2.5 percent and about 40 percent of the time. Mean outflow temperatures ranged from $23.0^{\circ} \mathrm{C}$ to $26.7^{\circ} \mathrm{C}$.

\section{Introduction}

Wetland kalo or taro (Colocasia esculenta (L.) Schott) is a vital part of the cultural and agricultural traditions of native Hawaiians. In some locations in Hawai 'i, significant competition between instream and offstream uses for limited surfacewater resources has led to litigation about rights to water for kalo cultivation and other uses. Appurtenant water rights of kuleana (private land awards to commoners) and kalo lands are preserved under the State Water Code, Hawai'i Revised Statutes Ch. 174C. Although irrigation flows for kalo cultivation have been measured with varying degrees of scientific accuracy, there is disagreement regarding the amount of water used and needed for successful kalo cultivation, with water temperature recognized as a critical factor. Most studies have focused on the amount of water consumed rather than the amount needed to flow through the irrigation system for successful kalo cultivation. In 2002, the Office of Hawaiian Affairs, State of Hawai 'i, cosponsored the "No Ka Lo 'i Conference" at the Kamakakūokalani Center for Hawaiian Studies, University of Hawai 'i at Mānoa. One of the outcomes of the conference was kalo farmers' expressed desire to document current water use and to protect and enhance kalo 
cultivation. The study documented in this report was pursued to help fulfill the priorities identified during that conference.

Wetland kalo is cultivated throughout Hawai' $\mathrm{i}$ in groups of shallow, watery terraces and pondfields, which native Hawaiians call lo'i kalo (fig.1). In this report, lo'i refers to an individual pondfield and lo' $i$ complex refers to a group of lo' $i$. Wetland cultivation is the primary and preferred source for kalo corms (food-bearing underground stem), which are processed into poi, a popular Hawaiian staple food. Wetland kalo requires cool water flowing over its roots to ensure the health and productivity of the crop. Irrigation, therefore, needs to provide more water than just what is consumed in the lo' $\mathrm{i}$ through evaporation from open water, transpiration through the kalo leaves, and percolation through the lo' $i$ bottom and sides. Irrigation flow must be controlled to provide enough cold water to keep the lo' $i$ adequately cool throughout the growing cycle. Water-temperature management in individual lo ' $\mathrm{i}$ is recognized as a water-management priority. Water temperature is generally considered the most critical physical factor in kalo cultivation water use, but rarely is it systematically measured or analyzed. Various studies suggest that it is best to keep lo' $\mathrm{i}$ water temperatures at about $25^{\circ} \mathrm{C}\left(77^{\circ} \mathrm{F}\right)$ or lower (Reppun v. Board of Water Supply, 1982; Penn, 1997). In general, a higher irrigation rate should dampen water heating and lower irrigation outflow temperature (Penn, 1997).

In cooperation with the Office of Hawaiian Affairs, State of Hawai 'i, the U.S. Geological Survey (USGS) undertook an investigation to evaluate current water use for commercial wetland kalo cultivation in Hawai' $i$. The objectives of this 2-year study are (1) to document current water use for selected lo'i complexes of various sizes on the islands of Kaua 'i, O'ahu, Maui, and Hawai 'i; and (2) to monitor the variation in inflow and outflow water temperatures of selected lo' $i$ and lo' $i$ complexes. Water-use and water-temperature data collected as part of this study provides baseline information on wetland kalo irrigation practices

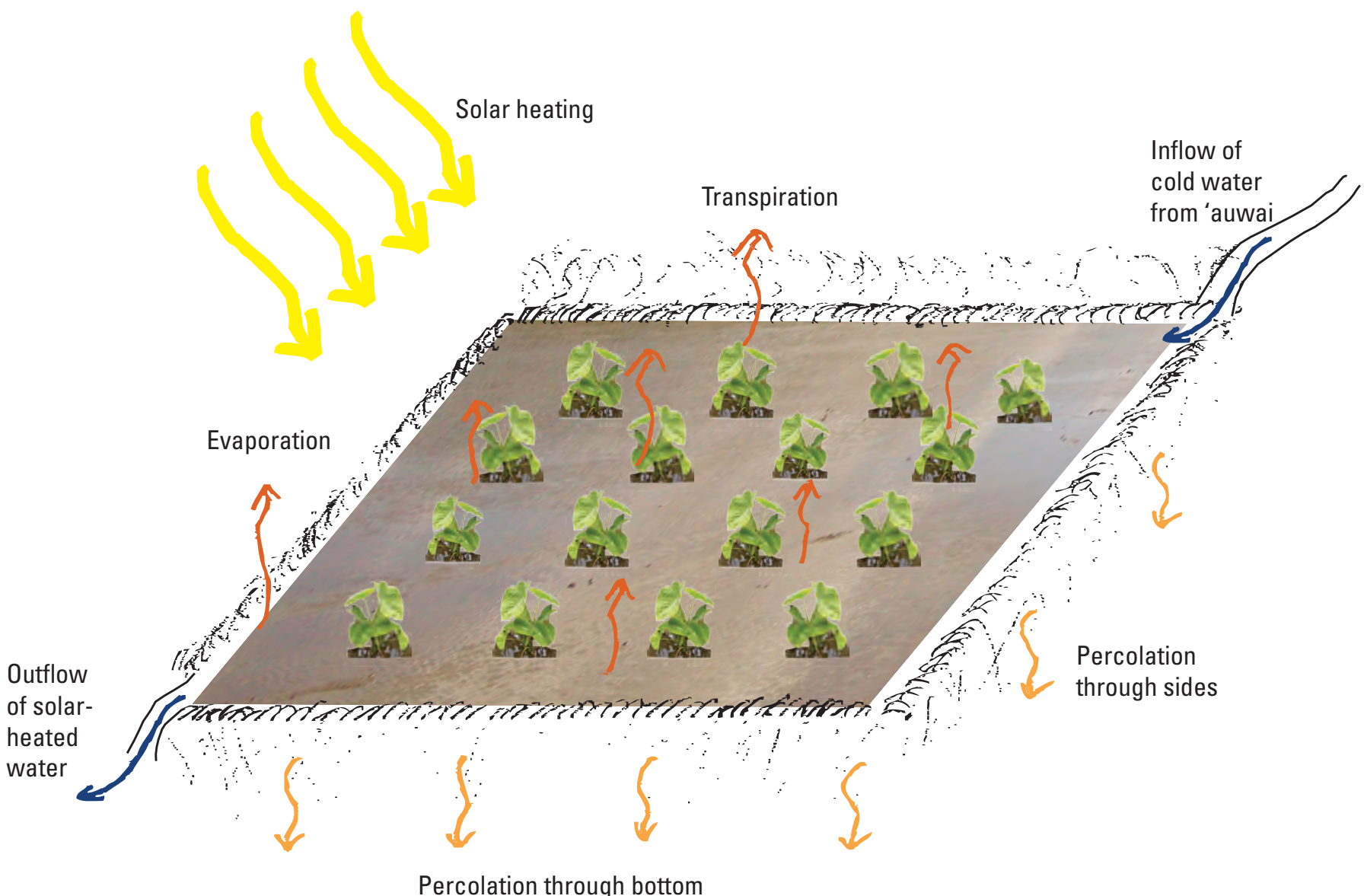

Figure 1. General movement of irrigation water in a lo'i kalo. 
for a variety of geographic settings in the Hawaiian Islands.

The 'auwai, or irrigation ditch system, constructed at each lo 'i complex transports water from streams to flood each lo'i. The design of the 'auwai and lo ' $i$ complexes varies from place to place, and from simple to complicated. An example of a simple lo' $\mathrm{i}$ complex design is where an 'auwai supplies water to a lo' $\mathrm{i}$ and flow is returned directly back to the stream. An example of a more complicated design exists in Ke'anae, Maui, where an 'auwai distributes water to multiple lo 'i staggered along the "auwai, and most lo " $i$ throughflow is returned to the 'auwai and mixed for reuse in downstream lo' $\mathrm{i}$ irrigation. Flow is ultimately released to the ocean at various locations around the $\mathrm{Ke}^{\text {'anae Peninsula }}$ and is too diffuse to accurately measure.

The most rigorous documented measurements of water used for wetland kalo cultivation were made in the 1930s at Hanapēpē, Kaua'i, by the University of Hawai'i and McBryde Sugar Company (Miles, 1931). Various water uses were measured including percolation in the lo ' $\mathrm{i}$ and 'auwai, transpiration, and evaporation. The highlighted results of 50,000 to 80,000 gallons per acre per day (gad) represent net loss or consumption (the difference between the amount of water flowing into a lo" $i$ complex and the amount flowing out) in the lo ' $\mathrm{i}$ and the researchers recognized "that a considerably greater amount would have to be diverted in order to successfully grow taro [kalo] with proper circulation of water." This statement is based on inflow measurements that ranged from 290,000 to $1,100,000 \mathrm{gad}$ (Penn, 1997). The results of this Hanapēpe study were used by the Hawai 'i courts to determine the water rights in connection with the various lands involved in the case. This was the last time that a final court decision was reached on this water rights issue. Some of the most frequently relied on flow-rate measurements were made by Watson (1964) and were presented as evidence in several seminal water-rights cases (Reppun v. Board of Water Supply, 1982; State of Hawai'i, 2000). Watson reported kalo water requirements of 40,000 gad, a figure also arrived at through a net loss determination. No consideration was given to the amount of throughflow needed to meet the cooling requirements of the lo'i. Penn (1997) reinterpreted Watson's findings to suggest that throughflow results for that study would be 100,000 to $250,000 \mathrm{gad}$. At Hanalei, Kaua'i, the U.S. Forest Service measured average inflow rates to a lo ' $\mathrm{i}$ complex of $87,500 \mathrm{gad}$ and estimated consumptive use for 220 acres in kalo production to be about 23,600 gad (Berg and others, 1997).

\section{Site Selection}

Twenty-eight geographic areas with significant kalo cultivation on the islands of Kaua'i, O'ahu, Moloka'i, Maui, and Hawai'i were initially identified (fig. 2). Each of the islands can be divided into two primary physiographic zones, windward and leeward, which relate to the exposure of these areas to the northeasterly trade winds and orographic rainfall. In general, windward areas receive higher rainfall than leeward areas. Twenty-one of the identified kalo cultivation areas receive rainfall consistent with the windward sides of the islands and seven cultivation areas receive rainfall consistent with the leeward sides of their respective islands. Of these areas, 10 were selected for this study ( 8 windward, 2 leeward), primarily on the basis of the diversity of environmental and agricultural conditions under which wetland kalo is grown and on the basis of landowner availability. In some areas, more than one complex was studied. Final site selection was made in consultation with the Office of Hawaiian Affairs, State of Hawai 'i, Onipa 'a Nā Hui Kalo, and the State of Hawai'i Department of Health.

The USGS collected flow and water-temperature data at the lo' $\mathrm{i}$ complex level and at the lo' $\mathrm{i}$ level. Data collection was designed to measure and document the amount of water being used by kalo farmers in a variety of geographic areas. The study was not designed to measure the consumption of water during kalo growth, but rather the throughflow of water used in lo' $i$ complexes where commercial cultivation generally is viable. For consistency in site selection, lo "i with crops near harvesting stage were selected for the lo 'i watertemperature data collection. Farmers stagger planting dates to obtain year-round production. Due to differences in water availability and irrigation-system configuration, irrigation practices vary. Farmers generally allocate a greater amount of water to lo ' $\mathrm{i}$ with crops at harvesting stage and less water to lo "i with crops at earlier stages to maximize the use of limited water resources. The selection of lo ${ }^{\prime} i$ with crops at harvesting stage ensured that flow and temperature data collected at different lo'i reflect similar irrigation conditions (continuous flooding of the mature crop). During field visits, farmers were interviewed about their irrigation practices and about their perceptions of their water supply. In general, most farmers believed that their supply of irrigation water was insufficient for proper kalo cultivation. 


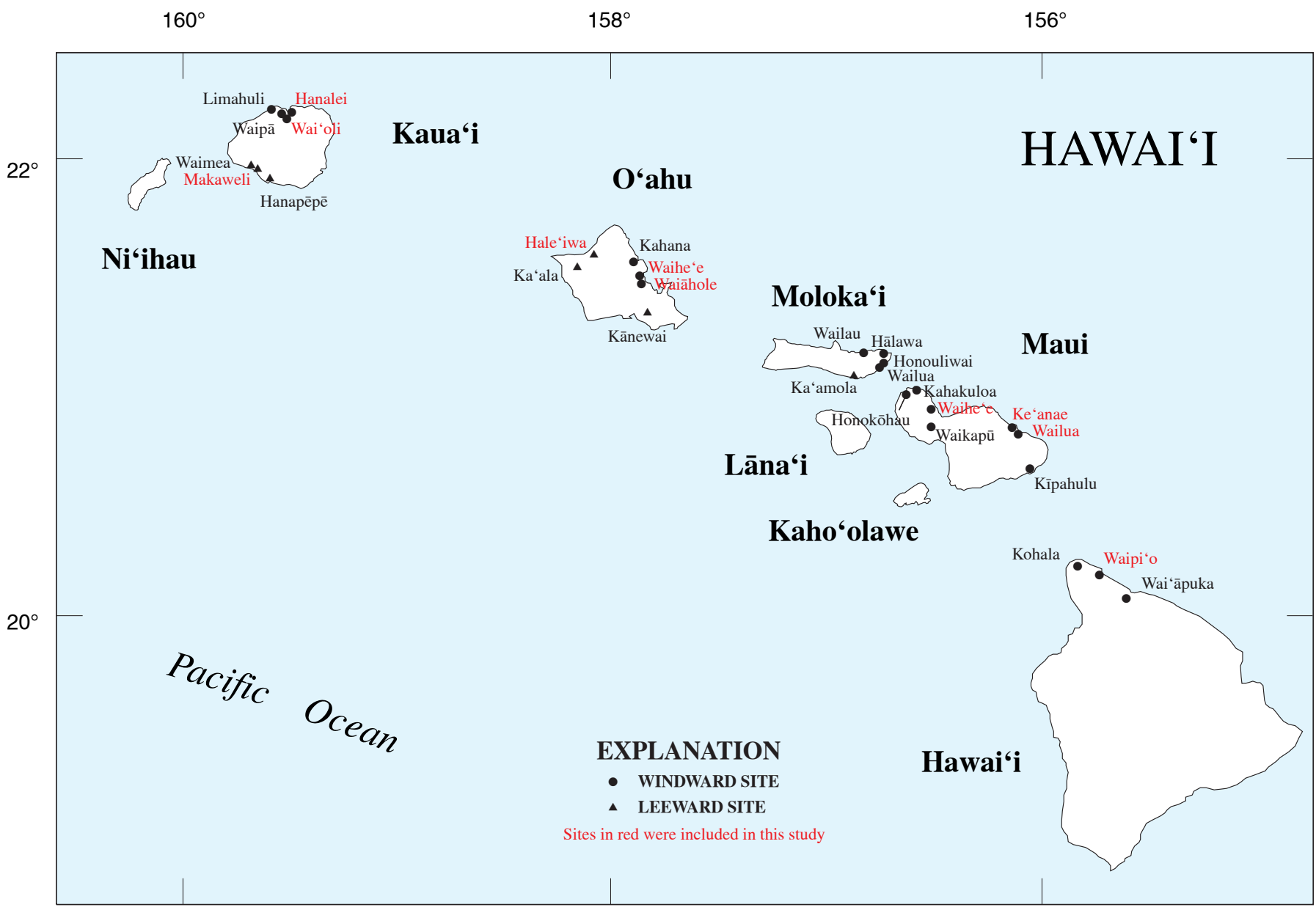

Figure 2. Location of significant areas of kalo cultivation, State of Hawai'i.

\section{Acknowledgments}

The authors wish to thank the stakeholders who helped to initiate and define the scope of this study-Dr. Jonathan Scheuer of the Office of Hawaiian Affairs, State of Hawai 'i, Charlie and Paul Reppun and other members of Onipa'a Nā Hui Kalo, and David Penn of the State of Hawai ' $i$ Department of Health. We also thank the many kalo farmers who provided lodging (and sometimes food), access to their lo ' $i$, knowledge of their irrigation systems, descriptions of their farming practices, and aloha during this study. We owe a special debt of gratitude to Charlie and Paul Reppun for providing volunteer help during visits to all of the study areas, for being the liaisons to all the kalo farmers, and for their general insight from more than 30 years of experience in kalo farming. David Reppun also provided volunteer help during the initial visits to Maui and Hawai' $i$.

\section{Discharge, Water-Temperature, and Area Data-Collection Methods}

Data collection was done during the dry season (June-October) when water requirements for cooling kalo are higher. In general, surface-water temperatures in the Hawaiian Islands begin to rise in April and remain elevated through September, mainly due to increased solar heating (Brasher and others, 2004; Gingerich and Wolff, 2005; Oki and others, 2006). Flow measurements generally were made during the warmest part of the day; temperature measurements were made every 15 minutes at each site for about a two-month period. 


\section{Discharge Measurements}

Measurements of the amount of water flowing into or out of the lo' $i$ complexes were made by using current-meter, volumetric-flow, or portable Parshall flume methods. Where channel conditions in the 'auwai permitted (for example, straight channels, non-turbulent flow, and relatively greater flow volumes), current-meter measurements were made. In the current-meter method, observations of width, depth, and velocity are collected at intervals in a cross section of the channel while the measurer wades in the channel (Rantz and others, 1982). Velocity measurements were made by using an acoustic Doppler velocimeter attached to a top-setting wading rod (fig. 3). Volumetric measurements were made where channel conditions did not permit current-meter measurements, where flow volumes were relatively low, or where volumetric measurements were more convenient than current-meter measurements. Volumetric measurements were made by repeated timed fillings of a calibrated five-gallon bucket and averaging the results (fig. 3). Typically, 10 independent measurements were made by using the calibrated bucket. Although relatively simple, the volumetric measurement is considered the most accurate way to measure low flows (Rantz and others, 1982). Parshall flume measurements were made in selected 'auwai where flow was too low for current-meter measurements but where the channel was narrow and flow was uniform. At these sites, the Parshall flume was installed and leveled, and repeated measurements were made in the flume stilling well after flow in the flume stabilized. At all sites, regardless of the method of measurement, a reference mark was set and checked at the beginning and ending of each workday to determine if the overall flow conditions changed during the day.

\section{Water-Temperature Measurements}

Water temperatures were measured every 15 minutes by using StowAway ${ }^{\circledR}$ Tidbit ${ }^{\circledR}$ thermistors from Onset Computer Corporation that were designed to operate in the $-20^{\circ} \mathrm{C}-50^{\circ} \mathrm{C}$ temperature range. Each thermistor was calibrated in the laboratory following USGS procedures (U.S. Geological Survey, 1997 to present) before installation in the field. Each thermistor was installed inside a 6-in. length of 1.25-in. diameter PVC pipe staked below the lowest expected water level in the 'auwai or 10 'i being monitored (fig. 4). Monitoring locations were in the shade, where possible, and chosen to avoid potentially stagnant flow. Each thermistor was field checked in place when deployed and again when
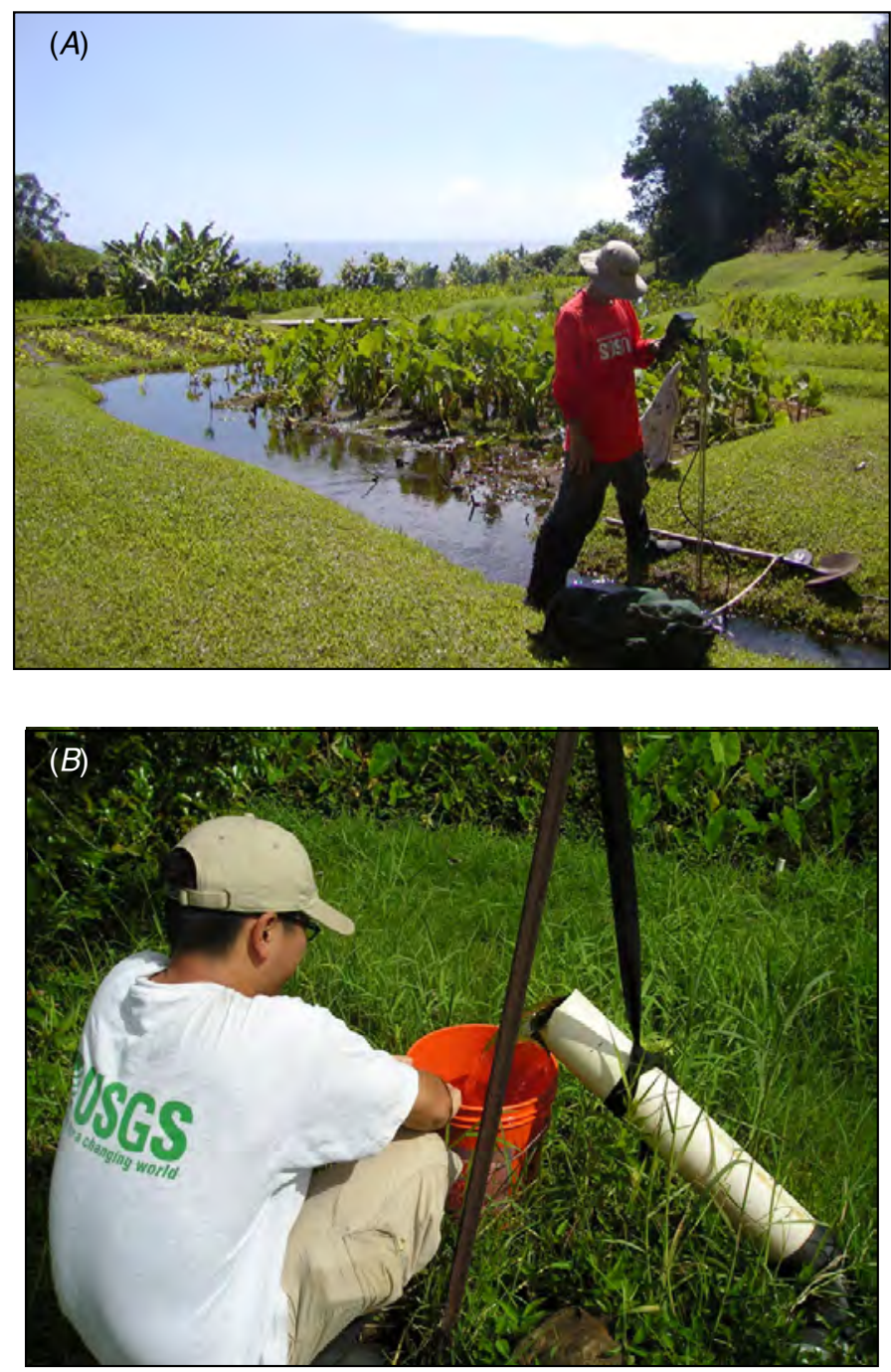

Figure 3. Flow measured by U.S. Geological Survey staff in lo'i kalo 'auwai with $(\boldsymbol{A})$ an acoustic Doppler velocimeter and $(\boldsymbol{B})$ the volumetric method.

retrieved by using a laboratory-calibrated field thermistor. Because field checks of the thermistors were within acceptable tolerances, no adjustments to the data were needed. A table showing equivalent temperature values in ${ }^{\circ} \mathrm{C}$ and ${ }^{\circ} \mathrm{F}$ is included (table 1).

\section{Area Measurements}

Measurements of the selected lo $i$ and lo' $i$ complex areas were made by walking the perimeter of each lo' $\mathrm{i}$ complex while recording the track with a handheld Global Positioning System (GPS) unit. Each perimeter track was uploaded from the GPS unit to a geographic information system (GIS) program and, where necessary, adjusted to overlay aerial images showing the appropriate lo'i com- 


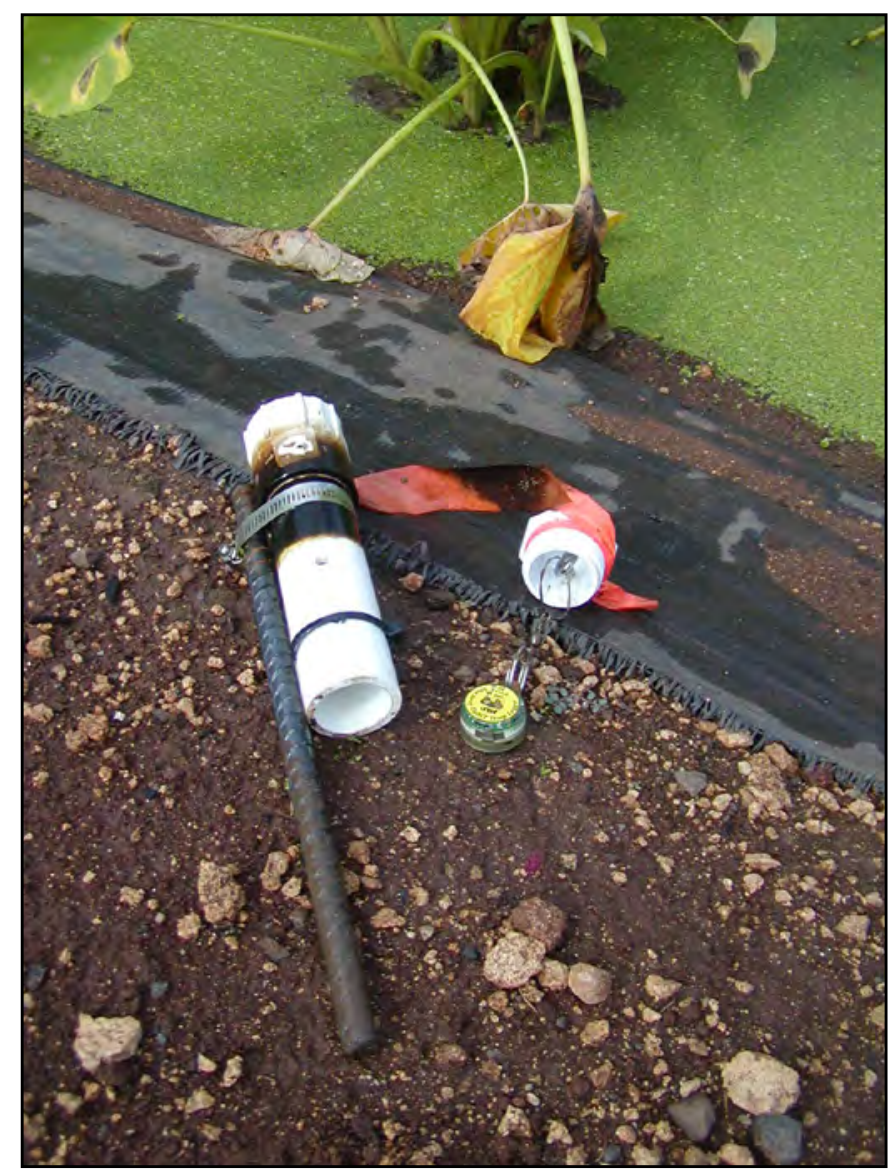

Figure 4. Thermistor and PVC housing used for collecting temperature measurements.

plexes. The areas, determined from the GIS program, include the cultivated and fallow lo 'i banks, pathways, and 'auwai inside the perimeter of the track. Removing the area of these non-water-covered parts of the lo' $i$ complexes from the total area was determined to be too difficult and subjective. The emphasis was, therefore, directed toward treating each lo 'i complex consistently.

\section{Discharge and Water- Temperature Data}

As part of this study, 62 flow measurements and 46 sets of temperature data were collected from kalo cultivation areas on four islands-Kaua' $\mathrm{i}, \mathrm{O}^{\prime} \mathrm{ahu}$, Maui, and Hawai' $i$. The flow and temperature measurement data collected as part of this study are available on the World Wide Web. Data from each station listed in the following tables can be retrieved
Table 1. Selected temperature conversions.

\begin{tabular}{|c|c|}
\hline $\begin{array}{c}\text { Temperature } \\
\text { (degrees Celsius) }\end{array}$ & $\begin{array}{c}\text { Temperature } \\
\text { ( degrees Fahrenheit) }\end{array}$ \\
\hline 18.0 & 64.4 \\
\hline 18.5 & 65.3 \\
\hline 19.0 & 66.2 \\
\hline 19.5 & 67.1 \\
\hline 20.0 & 68.0 \\
\hline 20.5 & 68.9 \\
\hline 21.0 & 69.8 \\
\hline 21.5 & 70.7 \\
\hline 22.0 & 71.6 \\
\hline 22.5 & 72.5 \\
\hline 23.0 & 73.4 \\
\hline 23.5 & 74.3 \\
\hline 24.0 & 75.2 \\
\hline 24.5 & 76.1 \\
\hline 25.0 & 77.0 \\
\hline 25.5 & 77.9 \\
\hline 26.0 & 78.8 \\
\hline 26.5 & 79.7 \\
\hline 27.0 & 80.6 \\
\hline 27.5 & 81.5 \\
\hline 28.0 & 82.4 \\
\hline 28.5 & 83.3 \\
\hline 29.0 & 84.2 \\
\hline 29.5 & 85.1 \\
\hline 30.0 & 86.0 \\
\hline 30.5 & 86.9 \\
\hline 31.0 & 87.8 \\
\hline 31.5 & 88.7 \\
\hline 32.0 & 89.6 \\
\hline 32.5 & 90.5 \\
\hline 33.0 & 91.4 \\
\hline 33.5 & 92.3 \\
\hline 34.0 & 93.2 \\
\hline 34.5 & 94.1 \\
\hline 35.0 & 95.0 \\
\hline 35.5 & 95.9 \\
\hline 36.0 & 96.8 \\
\hline 36.5 & 97.7 \\
\hline 37.0 & 98.6 \\
\hline 37.5 & 99.5 \\
\hline 38.0 & 100.4 \\
\hline 38.5 & 101.3 \\
\hline 39.0 & 102.2 \\
\hline 39.5 & 103.1 \\
\hline 40.0 & 104.0 \\
\hline
\end{tabular}


from the USGS National Water Information System database (NWIS) by clicking on the linked station name.

The flow and area tables in the following sections, presented by island, provide dates and times of measurements, flow rates in 'auwai irrigating the lo' $i$ and lo ' $i$ complexes, the GPS-measured areas of the selected lo ' $i$ and lo ' $i$ complexes, and water use based on the flow and area measurements. The temperature tables summarize (1) the dates of temperature-logger deployment; (2) the mean, maximum, and minimum temperature over the entire period of measurement; (3) the mean of the daily range in temperatures; (4) the range of times the highest temperature in any day occurred; (5) the percentage of measurements greater than $27^{\circ} \mathrm{C}$; and (6) the earliest and latest times during the day that the temperatures were greater than $27^{\circ} \mathrm{C}$. A temperature of $27^{\circ} \mathrm{C}$ is cited as the threshold temperature above which wetland kalo is more susceptible to fungi and associated rotting diseases (Ooka, 1994, Penn, 1997).

Two plots are presented for each temperature record collected in the study. One plot shows the entire record of 15-minute temperature data measurements for the length of time each temperature thermistor was deployed. These plots are useful for displaying how the temperature changed over time due to factors such as a period of cloudiness, increased or decreased irrigation caused by rainfall, or 'auwai problems. The other temperature plots provided show all of the temperature data plotted against the time of day each measurement was recorded. These plots indicate the daily pattern of temperature variation and are also useful for displaying the earliest and latest times of the day when the temperature reached the $27^{\circ} \mathrm{C}$ threshold.

\section{Kaua'i}

Three areas were measured on Kaua ' $\mathrm{i}$-Wai'oli and Hanalei (windward sites) and Makaweli (leeward site). Flow measurements were made on August 7-9, 2005, when the temperature loggers were deployed, and on September 21-23, 2005, when the temperature loggers were removed (tables 2 and 3). The Wai 'oli area is supplied through the Wai'oli 'Auwai with water diverted from the Wai' oli River (fig. 4). Of the numerous lo'i complexes supplied by the Wai 'oli 'Auwai, four independent lo i complexes were studied. Twelve flow measurements were made, and ten temperature loggers were deployed at selected inflow and outflow locations (figs. 5 and 6).

The Hanalei area is supplied through the "China Ditch" with water diverted from the Hanalei River (fig. 7). One lo'i complex was studied in this area. Four flow measurements were made, and three temperature loggers were deployed in the Hanalei area (figs. 8 and 9).

The Makaweli area is supplied through the $\mathrm{Pu}$ 'ulima Ditch with water diverted from the Makaweli River; one lo'i complex was studied in this area (fig. 10). One flow measurement was made, and three temperature loggers were deployed in the Makaweli area (figs. 11 and 12). A flow measurement was not made during the second visit to the Makaweli area because of damage to the diversion structure. 
Table 2. Summary of discharge measurements and areas for selected lo'i complexes, Island of Kaua'i.

[Mgal/d, million gallons per day; gad, gallons per acre per day; --, not available; average water use is determined by summing the averages of each lo' $\mathrm{i}$ or lo'i complex and dividing by the number of lo' $\mathrm{i}$ or lo' $\mathrm{i}$ complexes]

\begin{tabular}{|c|c|c|c|c|c|c|c|c|c|c|c|c|c|}
\hline \multirow[b]{2}{*}{$\begin{array}{l}\text { Geographic } \\
\text { designation }\end{array}$} & \multirow[b]{2}{*}{ Area } & \multicolumn{6}{|c|}{ Complex } & \multicolumn{6}{|c|}{ Lo'i } \\
\hline & & Station & $\begin{array}{c}\text { Irrigation } \\
\text { area } \\
\text { (acre) }\end{array}$ & Date & $\begin{array}{c}\text { Measurement } \\
\text { time }\end{array}$ & $\begin{array}{c}\text { Discharge } \\
\text { (Mgal/d) }\end{array}$ & $\begin{array}{l}\text { Water use } \\
\text { (gad) }\end{array}$ & Station & $\begin{array}{c}\text { Irrigation } \\
\text { area } \\
\text { (acre) }\end{array}$ & Date & $\begin{array}{c}\text { Measurement } \\
\text { time }\end{array}$ & $\begin{array}{c}\text { Discharge } \\
\text { (Mgal/d) }\end{array}$ & $\begin{array}{l}\text { Water use } \\
\text { (gad) }\end{array}$ \\
\hline \multirow[t]{8}{*}{ Windward } & Wai'oli & Ka01A-CI & 32.39 & $8 / 8 / 2005$ & 0850 & 4.2 & 130,000 & & & & & & \\
\hline & & & & $9 / 21 / 2005$ & 1147 & 4.2 & 130,000 & & & & & & \\
\hline & & Ka01B-CI & 2.98 & $8 / 8 / 2005$ & 1000 & 0.36 & 120,000 & Ka01B-LI & 0.21 & $8 / 8 / 2005$ & 1400 & 0.076 & 370,000 \\
\hline & & & & $9 / 21 / 2005$ & 1246 & $0.55^{\mathrm{a}}$ & 180,000 & & & $9 / 21 / 2005$ & 1337 & 0.047 & 230,000 \\
\hline & & Ka01C-CI & 5.46 & $8 / 8 / 2005$ & 1132 & 0.54 & 100,000 & Ka01C-LI & 0.16 & $8 / 8 / 2005$ & 1030 & 0.028 & 170,000 \\
\hline & & & & $9 / 22 / 2005$ & 1211 & $0.38^{\mathrm{b}}$ & 70,000 & & & $9 / 22 / 2005$ & 1255 & 0.019 & 120,000 \\
\hline & & Ka01D-CI & 4.18 & $8 / 8 / 2005$ & 1505 & 0.15 & 36,000 & & & & & & \\
\hline & & & & $9 / 22 / 2005$ & 1510 & 0.25 & 60,000 & & & & & & \\
\hline \multirow[t]{2}{*}{ Windward } & Hanalei & $\mathrm{Ka} 02-\mathrm{CI}$ & 53.63 & $8 / 7 / 2005$ & 1708 & $3.7^{\mathrm{c}}$ & 69,000 & $\mathrm{Ka} 02 \mathrm{~A}-\mathrm{LO}$ & 0.51 & 8/9/2005 & 0910 & 0.10 & -- \\
\hline & & & & $9 / 21 / 2005$ & 1604 & $4.2^{\mathrm{d}}$ & 78,000 & & & $9 / 21 / 2005$ & 1722 & 0.15 & -- \\
\hline \multirow[t]{2}{*}{ Leeward } & Makaweli & $\mathrm{Ka} 03-\mathrm{CI}$ & 0.68 & $8 / 9 / 2005^{\mathrm{e}}$ & 1241 & 0.090 & 260,000 & & & & & & \\
\hline & & & & $9 / 23 / 2005^{\mathrm{f}}$ & -- & -- & -- & & & & & & \\
\hline number & & & 6 & & & & 6 & & 3 & & & & 2 \\
\hline minimum & & & 0.68 & & & & 36,000 & & 0.16 & & & & 120,000 \\
\hline maximum & & & 53.63 & & & & 260,000 & & 0.51 & & & & 370,000 \\
\hline average & & & 16.55 & & & & 120,000 & & 0.29 & & & & 220,000 \\
\hline
\end{tabular}

${ }^{\text {a}}$ Flow higher than normal due to leakage at field inlet gate.

bFlow lower than normal due to damaged upstream diversion dam.

'Intake gate was not fully open.

${ }^{\mathrm{d}} \mathrm{Higher}$ flow because intake gate was fully open.

${ }^{\text {e}}$ Two intake pipes (4-inch and 3-inch diameter) are used to divert water from the 'auwai to the lo'i. Flow measurement only was made at the the 4-inch-intake pipe on 8/9/2005. Farmer indicated that the 3inch-pipe will be replaced eventually with a 4-inch-pipe, so two times the 4-inch-pipe measurement would be a reasonable estimate of typical flow to the lo 'i.

'Flow was not measured because flow in the 'auwai was much lower than normal due to damaged upstream diversion dam. 
Table 3. Water-temperature statistics based on measurements collected at 15-minute intervals for lo'i complexes on the Island of Kaua'i. $\left[{ }^{\circ} \mathrm{C}\right.$, degrees Celsius; na, not applicable $]$

\begin{tabular}{|c|c|c|c|c|c|c|c|c|c|c|}
\hline \multirow{2}{*}{$\begin{array}{l}\text { Geographic } \\
\text { designation }\end{array}$} & \multirow{2}{*}{ Area } & \multirow{2}{*}{ Station } & \multirow{2}{*}{ Period of record } & \multicolumn{3}{|c|}{ Temperature $\left({ }^{\circ} \mathrm{C}\right)$} & \multirow{2}{*}{$\begin{array}{l}\text { Range of times } \\
\text { daily peak } \\
\text { temperatures } \\
\text { occurred }\end{array}$} & \multicolumn{3}{|c|}{$\begin{array}{l}\text { Temperature measurements } \\
\text { areater than } 27^{\circ} \mathrm{C}\end{array}$} \\
\hline & & & & Mean & Range & $\begin{array}{c}\text { Mean daily } \\
\text { range }\end{array}$ & & Percent & $\begin{array}{l}\text { Earliest } \\
\text { time of day }\end{array}$ & $\begin{array}{c}\text { Latest time } \\
\text { of day }\end{array}$ \\
\hline Windward & Wai'oli & $\begin{array}{l}\text { Ka01A-LI } \\
\text { Ka01A-LO } \\
\text { Ka01B-Cl } \\
\text { Ka01B-LI } \\
\text { Ka01B-LO } \\
\text { Ka01C-LI } \\
\text { Ka01C-LO } \\
\text { Ka01D-Cl } \\
\text { Ka01D-LI } \\
\text { Ka01D-LO }\end{array}$ & $\begin{array}{l}8 / 8 / 05-9 / 22 / 05 \\
8 / 8 / 05-9 / 22 / 05 \\
8 / 8 / 05-9 / 22 / 05 \\
8 / 8 / 05-9 / 22 / 05 \\
8 / 8 / 05-9 / 22 / 05 \\
8 / 8 / 05-9 / 22 / 05 \\
8 / 8 / 05-9 / 22 / 05 \\
8 / 8 / 05-9 / 22 / 05 \\
8 / 8 / 05-9 / 22 / 05 \\
8 / 8 / 05-9 / 22 / 05\end{array}$ & $\begin{array}{l}21.4 \\
25.5 \\
21.4 \\
22.6 \\
24.7 \\
23.5 \\
25.9 \\
21.8 \\
23.5 \\
26.2\end{array}$ & $\begin{array}{l}19.5-23.3 \\
19.7-34.1 \\
19.5-23.6 \\
19.6-28.1 \\
20.5-30.7 \\
19.7-30.6 \\
20.0-33.5 \\
19.5-24.1 \\
19.2-31.8 \\
22.1-30.8\end{array}$ & $\begin{array}{l}1.2 \\
5.5 \\
1.2 \\
2.8 \\
3.5 \\
3.1 \\
4.3 \\
1.5 \\
4.6 \\
3.3\end{array}$ & $\begin{array}{l}1315-1830 \\
1200-1700 \\
1315-1815 \\
1130-1645 \\
1330-1845 \\
1145-1645 \\
1145-1545 \\
1130-1745 \\
1145-1630 \\
1400-1730\end{array}$ & $\begin{array}{c}0.0 \\
32.6 \\
0.0 \\
0.8 \\
16.8 \\
8.1 \\
31.3 \\
0.0 \\
14.9 \\
33.5\end{array}$ & $\begin{array}{c}\text { na } \\
0930 \\
0000 \\
1415 \\
1215 \\
1045 \\
1000 \\
\text { na } \\
1130 \\
1115\end{array}$ & $\begin{array}{c}\text { na } \\
2045 \\
0000 \\
1700 \\
2045 \\
1800 \\
2100 \\
\text { na } \\
1815 \\
2245\end{array}$ \\
\hline Windward & Hanalei & $\begin{array}{l}\mathrm{KaO} 2-\mathrm{Cl} \\
\mathrm{KaO} 2-\mathrm{LI} \\
\mathrm{KaO} 2-\mathrm{LO}\end{array}$ & $\begin{array}{l}8 / 8 / 05-9 / 21 / 05 \\
8 / 8 / 05-9 / 21 / 05 \\
8 / 8 / 05-9 / 21 / 05\end{array}$ & $\begin{array}{l}23.7 \\
24.2 \\
26.7\end{array}$ & $\begin{array}{l}21.3-26.9 \\
21.5-27.4 \\
21.9-33.5\end{array}$ & $\begin{array}{l}2.2 \\
2.3 \\
6.3\end{array}$ & $\begin{array}{l}1445-2030 \\
1245-1815 \\
1215-1700\end{array}$ & $\begin{array}{c}0.0 \\
0.2 \\
40.4\end{array}$ & $\begin{array}{l}0000 \\
1445 \\
1045\end{array}$ & $\begin{array}{l}0000 \\
1600 \\
2345\end{array}$ \\
\hline Leeward & Makaweli & $\begin{array}{l}\mathrm{KaO3}-\mathrm{Cl} \\
\mathrm{KaO3}-\mathrm{LI} \\
\mathrm{KaO3}-\mathrm{LO}\end{array}$ & $\begin{array}{l}8 / 9 / 05-9 / 23 / 05 \\
8 / 9 / 05-9 / 23 / 05 \\
8 / 9 / 05-9 / 23 / 05\end{array}$ & $\begin{array}{l}24.8 \\
25.8 \\
24.5\end{array}$ & $\begin{array}{l}21.5-28.3 \\
21.3-36.9 \\
19.7-35.7\end{array}$ & $\begin{array}{l}2.6 \\
3.8 \\
3.9\end{array}$ & $\begin{array}{l}1400-1815 \\
1030-1930 \\
0945-2045\end{array}$ & $\begin{array}{c}9.0 \\
23.8 \\
10.5\end{array}$ & $\begin{array}{l}1330 \\
0830 \\
0930\end{array}$ & $\begin{array}{l}2115 \\
2330 \\
1930\end{array}$ \\
\hline
\end{tabular}


$159^{\circ} 30^{\prime} 15^{\prime \prime} \mathrm{W}$

$159^{\circ} 30^{\prime} 0 " \mathrm{~W}$

$159^{\circ} 29^{\prime} 45^{\prime \prime} \mathrm{W}$

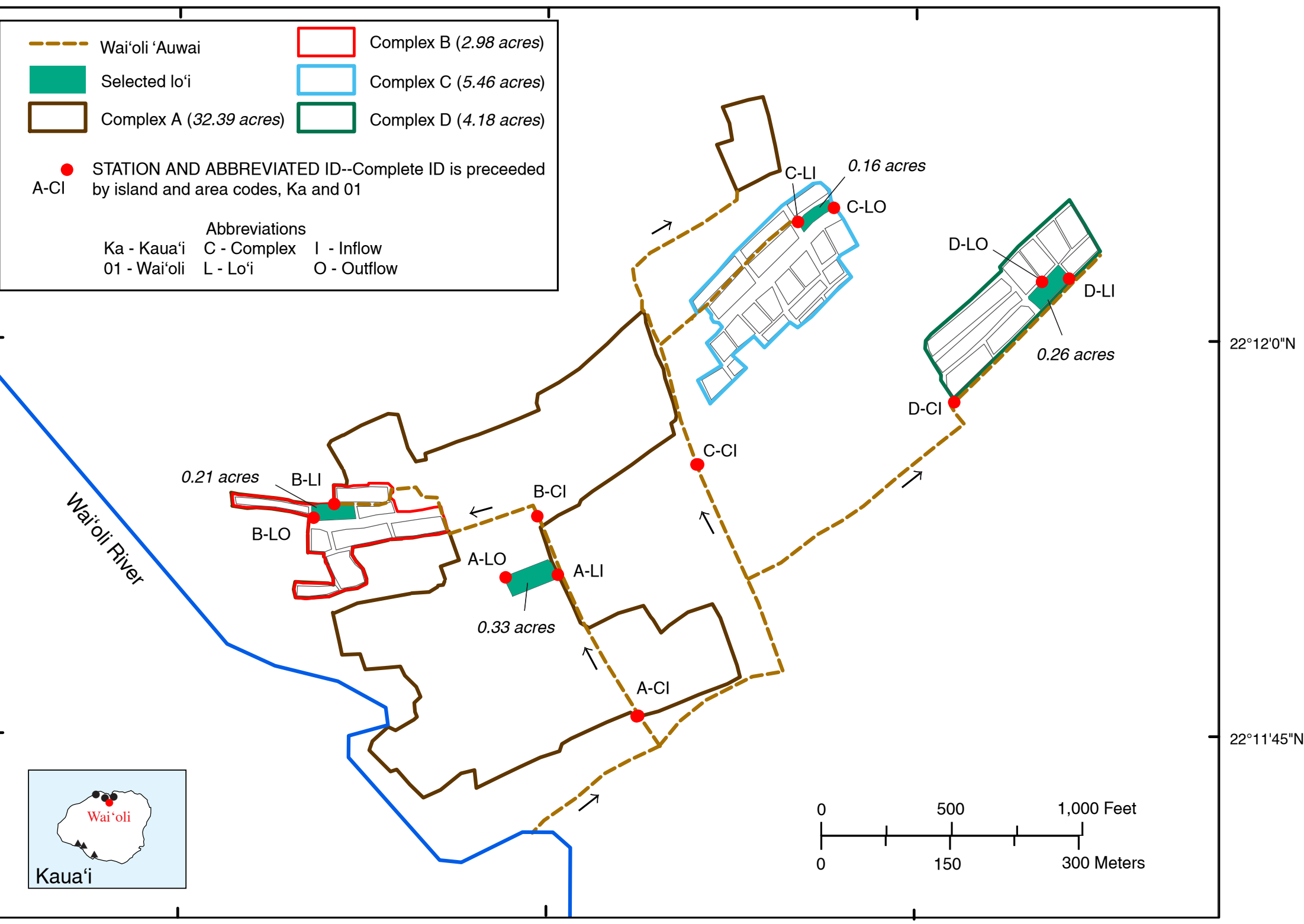

Figure 5. Wai'oli lo'i complex, Island of Kaua'i. 

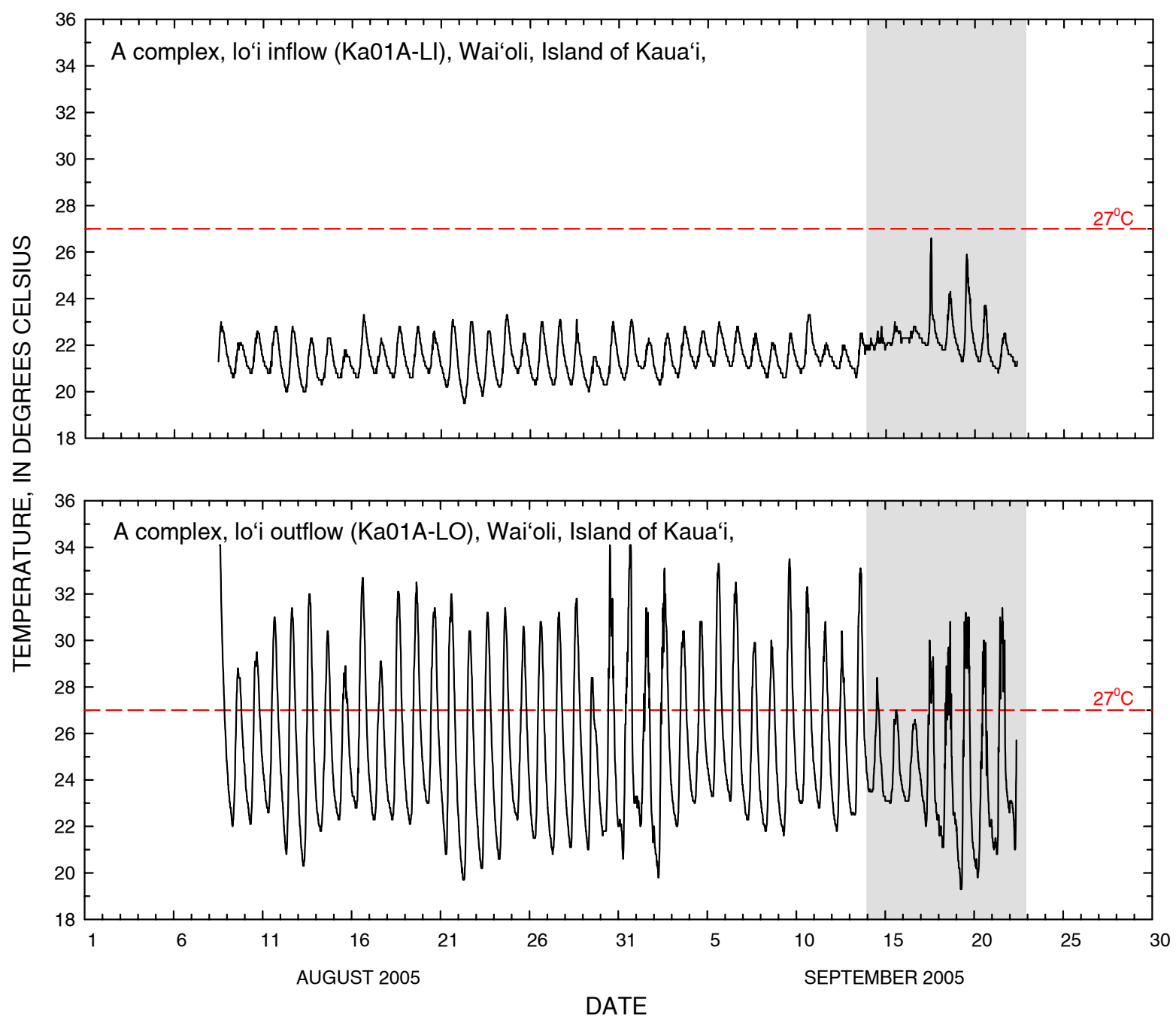

Highlighted periods indicate atypical irrigated conditions. During September 14-15, 2005, a heavy rainstorm flooded the complex and caused damage in the Wai'oli irrigation system by depositing heavy debris around the diversion dam and 'auwai. During the following period, the diversion dam and the 'auwai were being repaired, which significantly altered flow conditions in the irrigation system. During September 18-22, 2005, the farmer indicated that inflow to the selected lo'i was reduced because the kalo was ready to be harvested.

Figure 6. Water temperature in Wai'oli lo'i complex, Island of Kaua'i. 

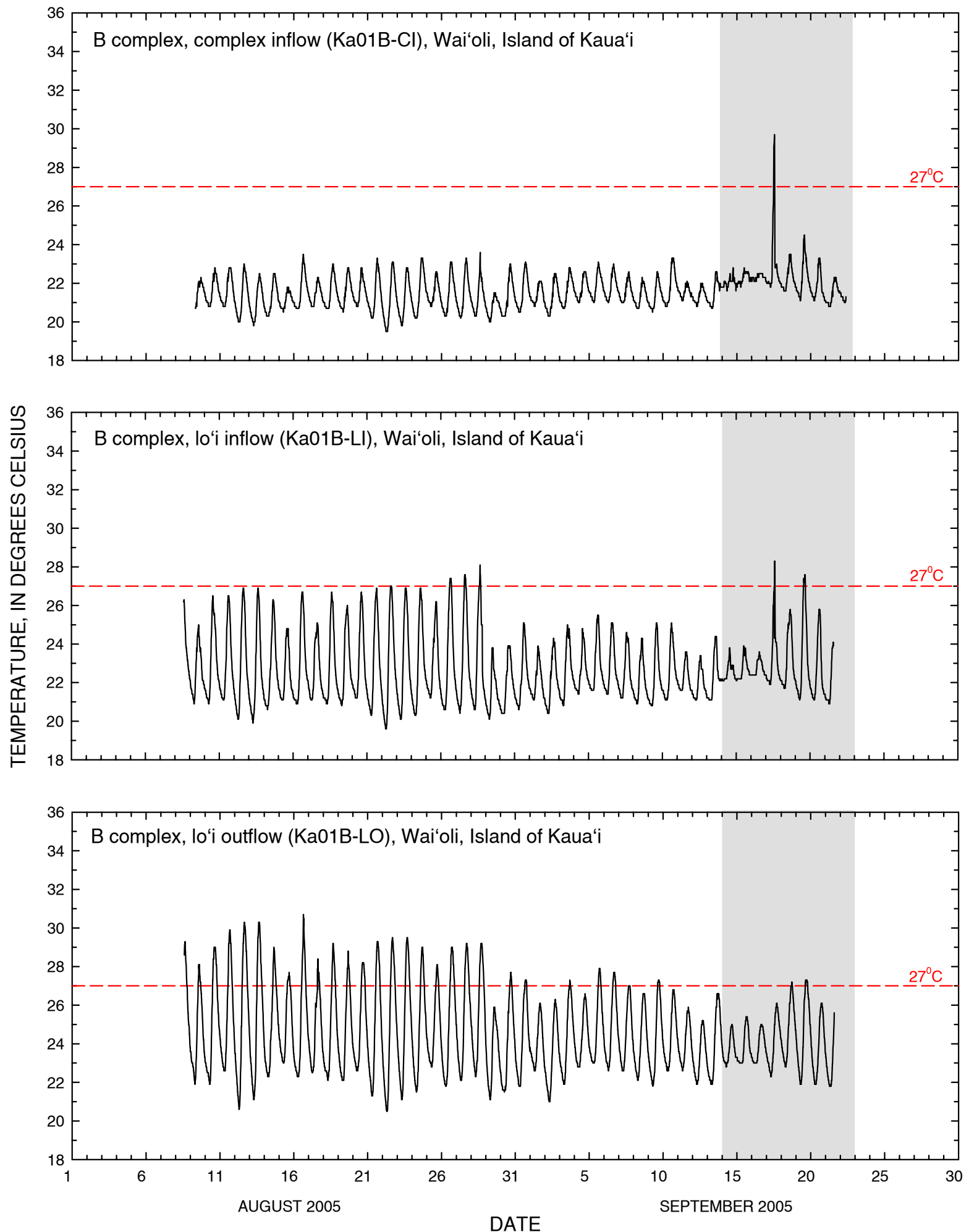

Highlighted periods indicate atypical irrigated conditions. During September 14-15, a heavy rainstorm flooded the complex and caused damages in the Wai'oli irrigation system by depositing heavy debris around the diversion dam and 'auwai. Afterward, the diversion dam and the 'auwai were being repaired, which significantly altered flow conditions in the irrigation system.

Figure 6. Continued. 


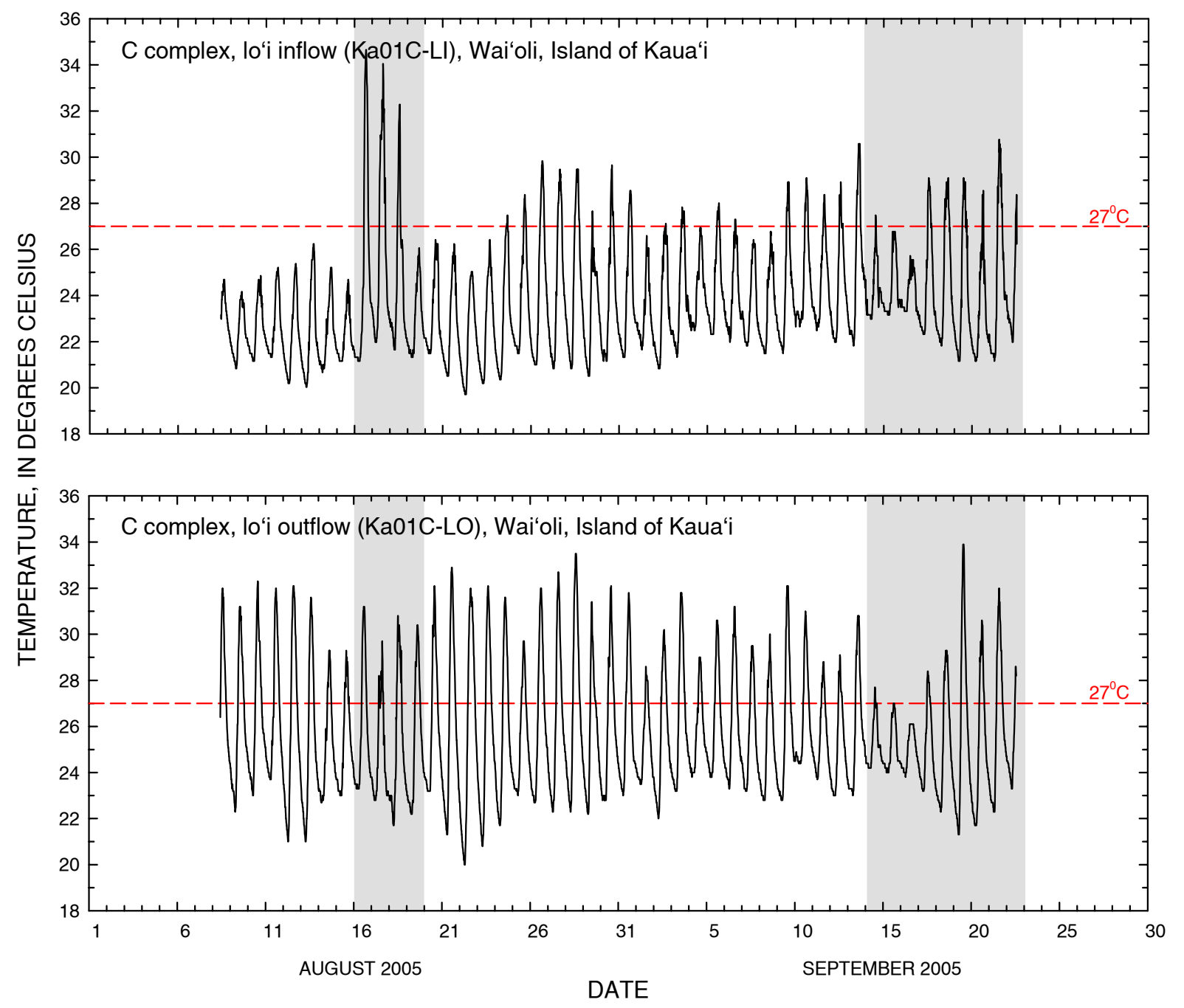

Highlighted periods indicate atypical irrigated conditions. During August 16-19, Io'i was dried out. During September 14-15, a heavy rainstorm flooded the complex and caused damages in the Wai'oli irrigation system by depositing heavy debris around the diversion dam and 'auwai. During the following period, the diversion dam and the 'auwai were being repaired which significantly altered flow conditions in the irrigation system.

Figure 6. Continued. 

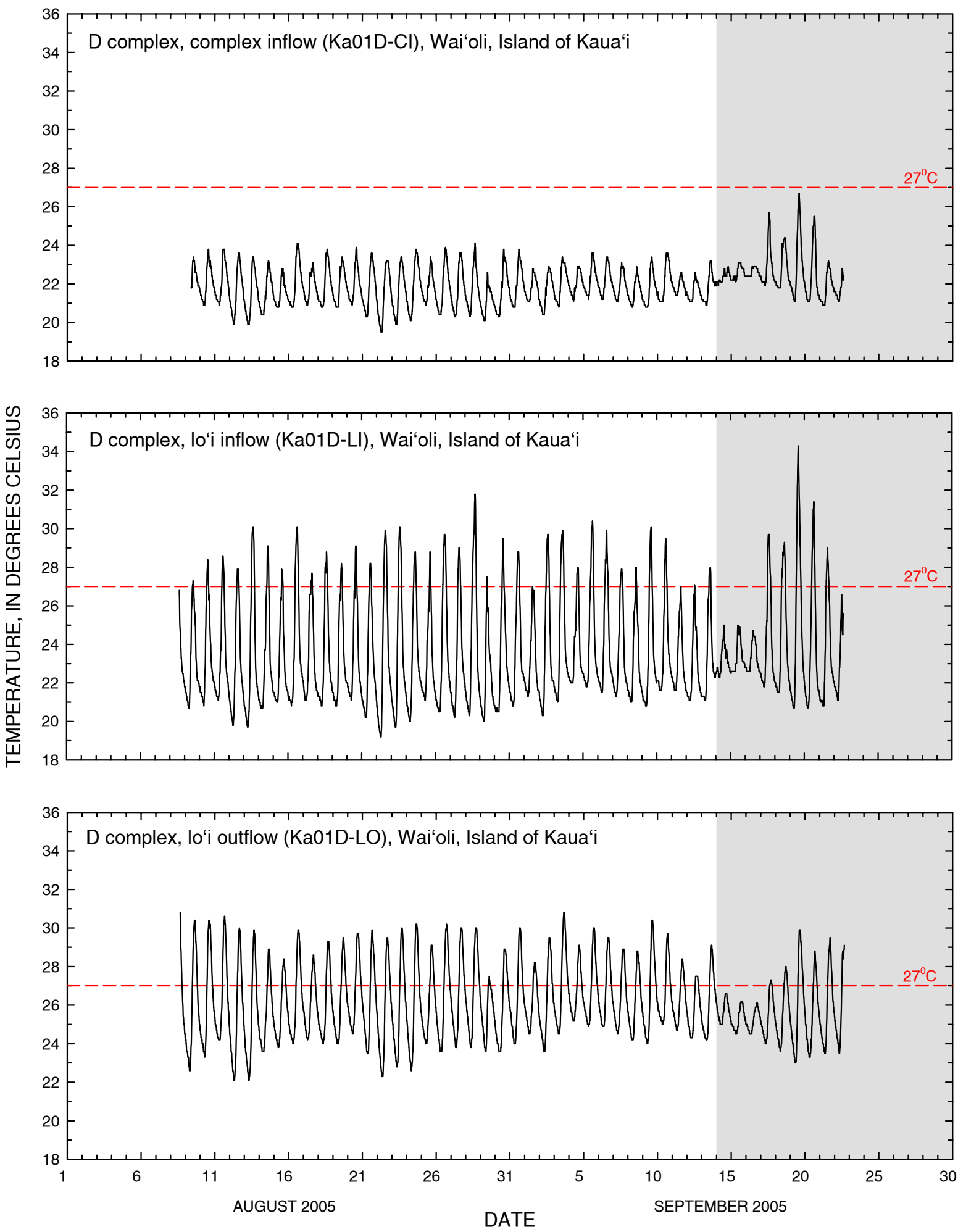

Highlighted periods indicate atypical irrigated conditions. During September 14-15, a heavy rainstorm flooded the complex and caused damages in the Wai'oli irrigation system by depositing heavy debris around the diversion dam and 'auwai. During the following period, the diversion dam and the 'auwai were being repaired which significantly altered flow conditions in the irrigation system.

Figure 6. Continued. 


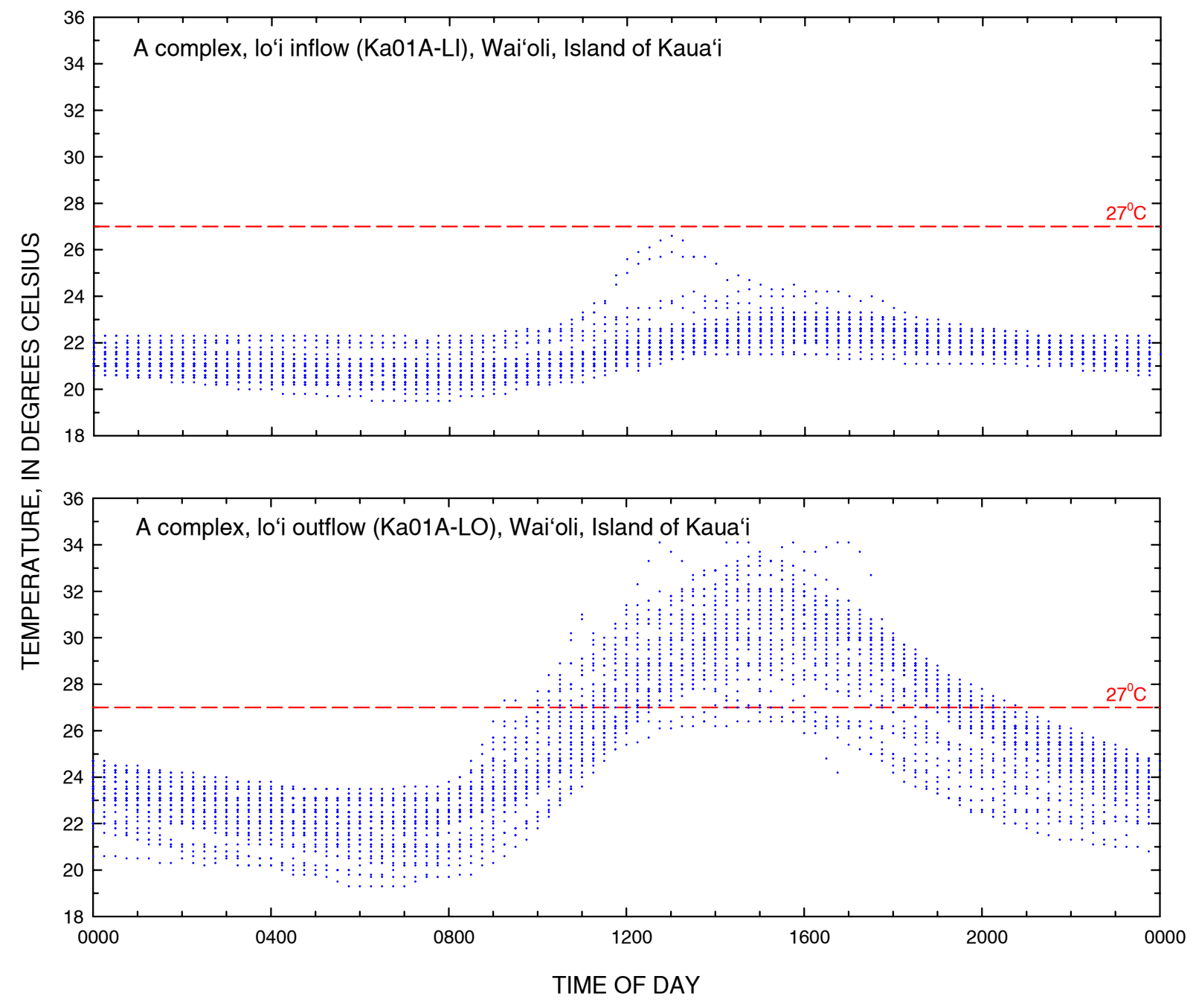

Figure 7. Daily pattern of water temperature in Wai'oli lo'i complex, Island of Kaua'i. Plot shows all temperature data plotted against the time of day that each measurement was recorded. 

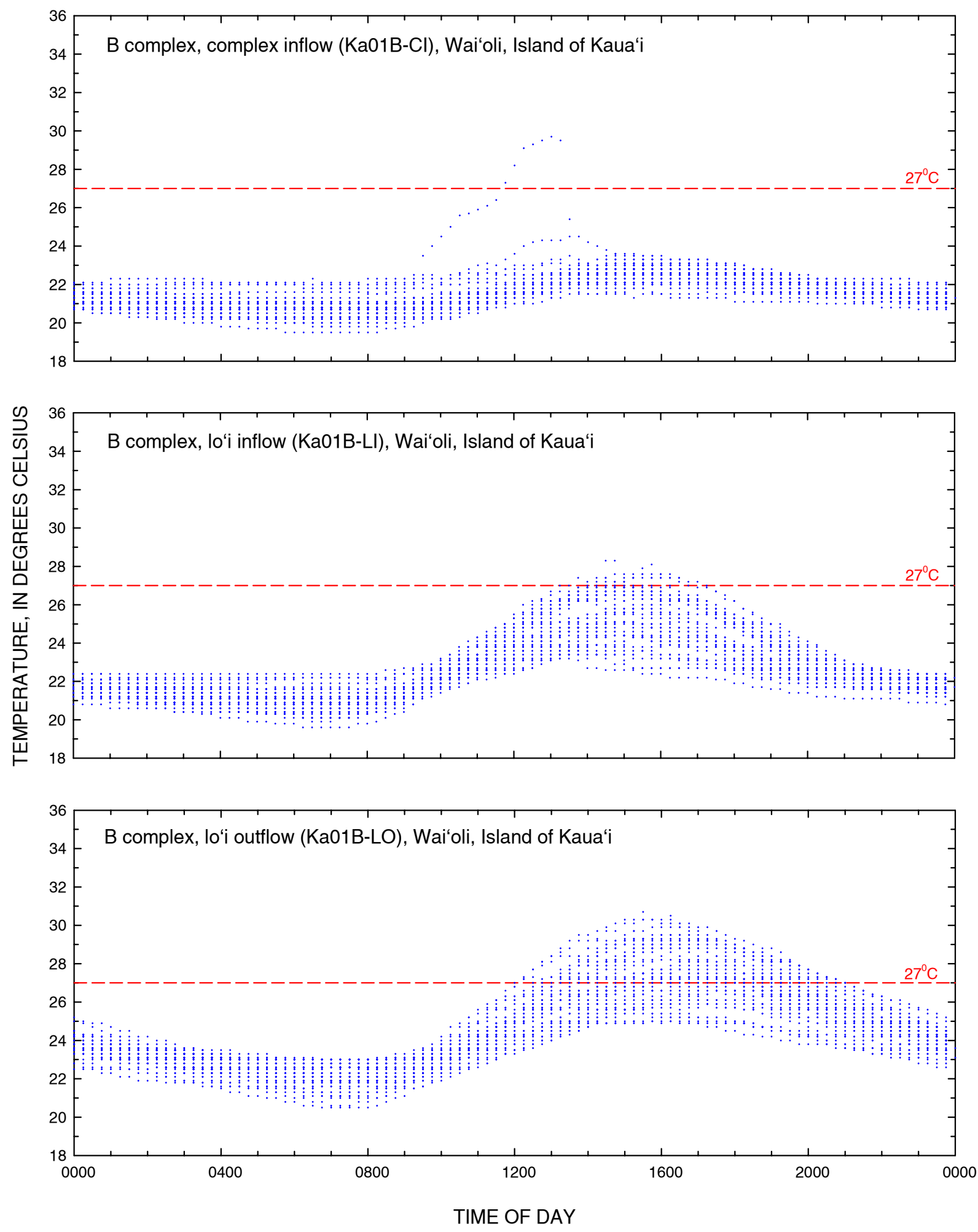

Figure 7. Continued. 


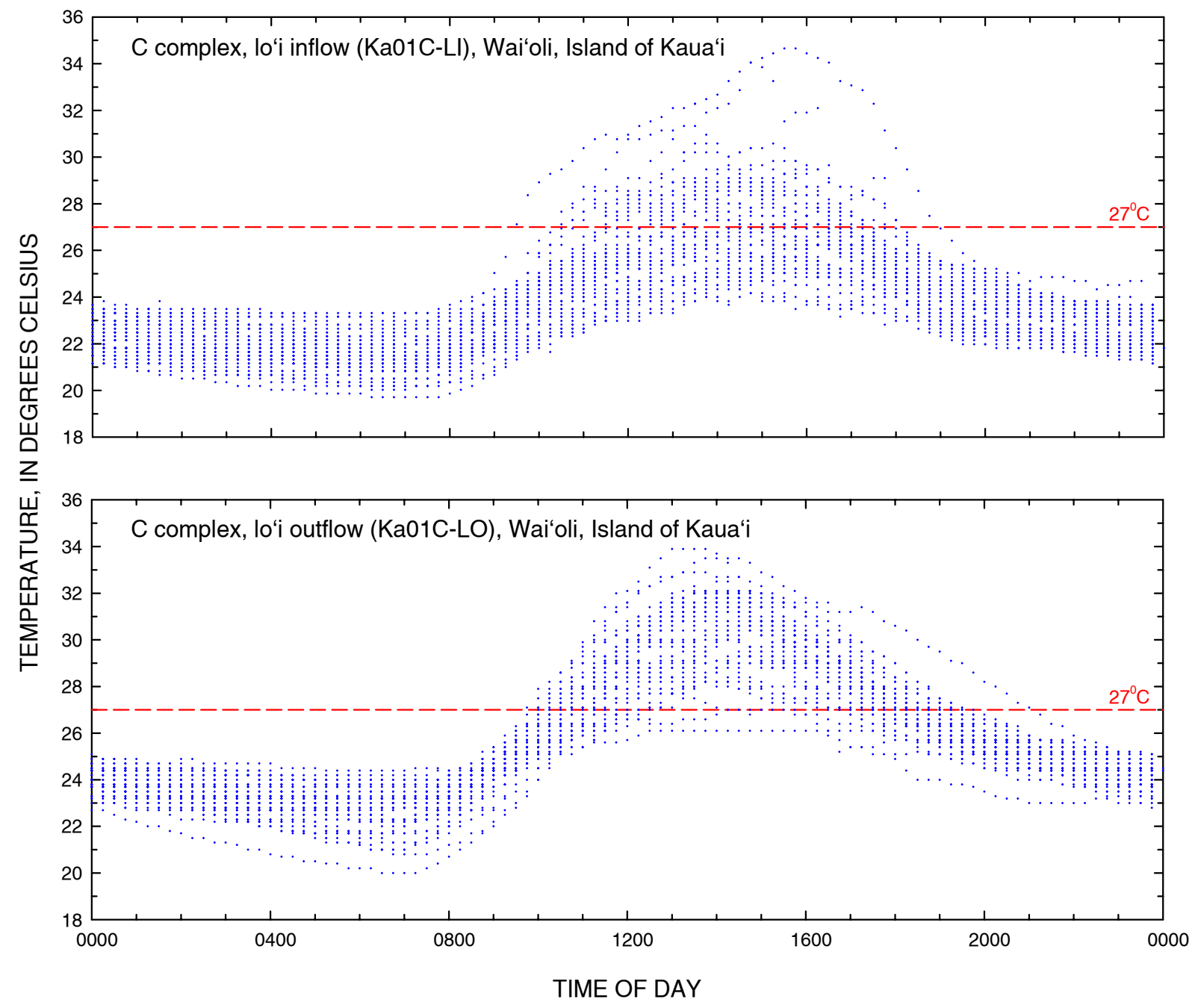

Figure 7. Continued. 

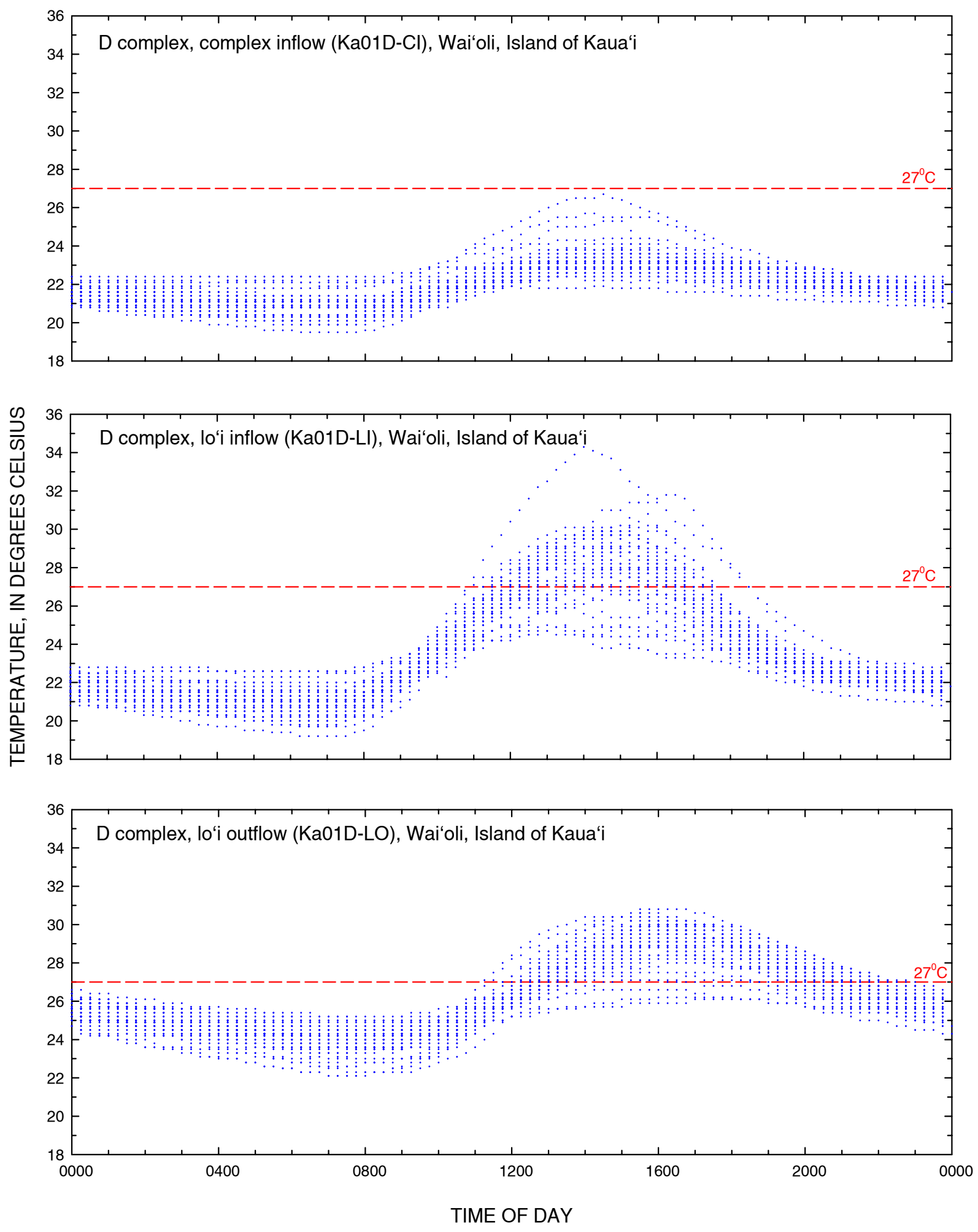

Figure 7. Continued. 


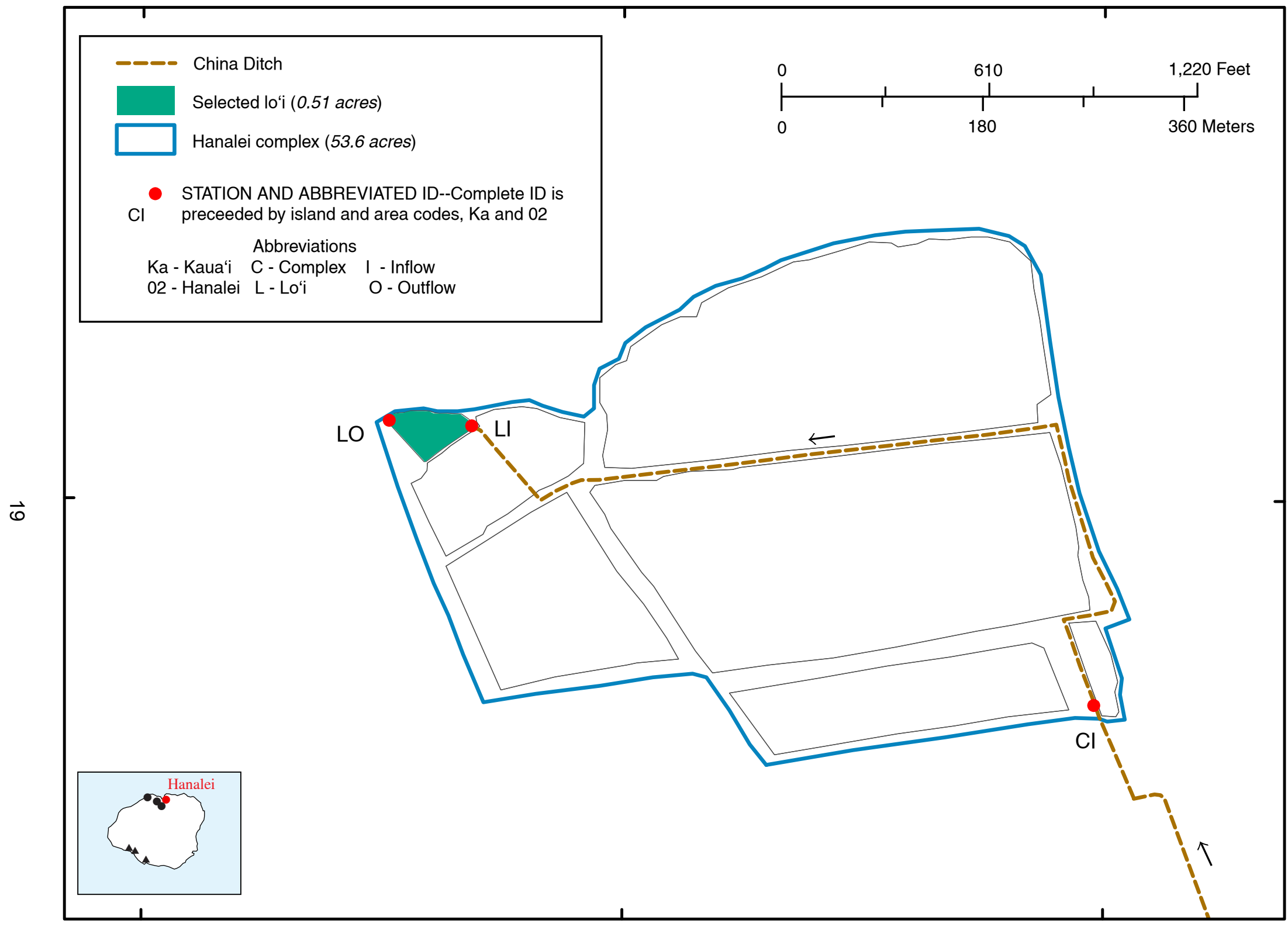

$22^{\circ} 12^{\prime} 30^{\prime \prime} \mathrm{N}$

Figure 8. Hanalei lo'i complex, Island of Kaua'i. 

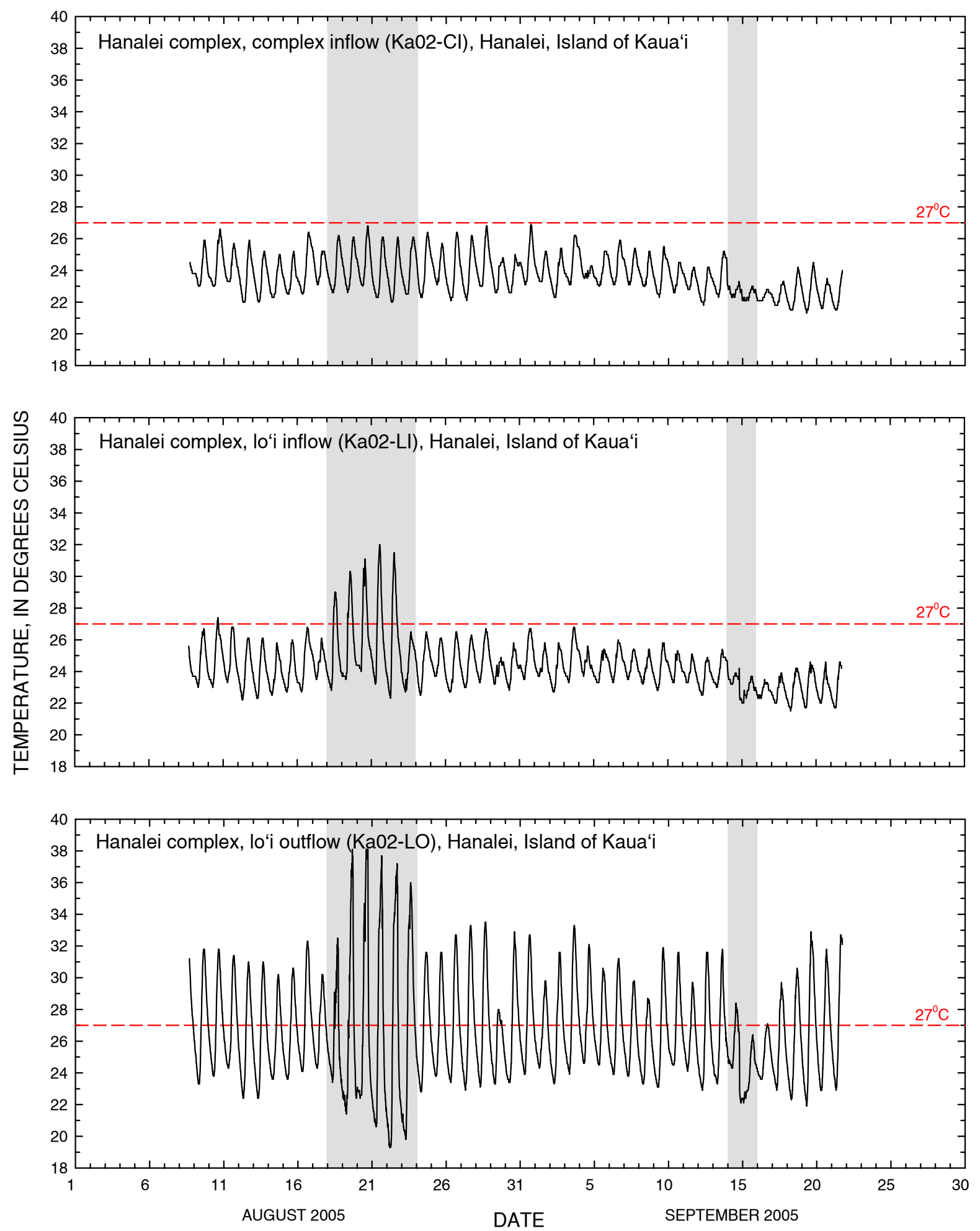

Highlighted periods indicate atypical irrigation conditions. During August 18-23, the selected lo'i was dried out for fertilization. During September 14-15, entire complex was flooded by heavy rainstorm.

Figure 9. Water temperature in Hanalei lo'i complex, Island of Kaua'i. 

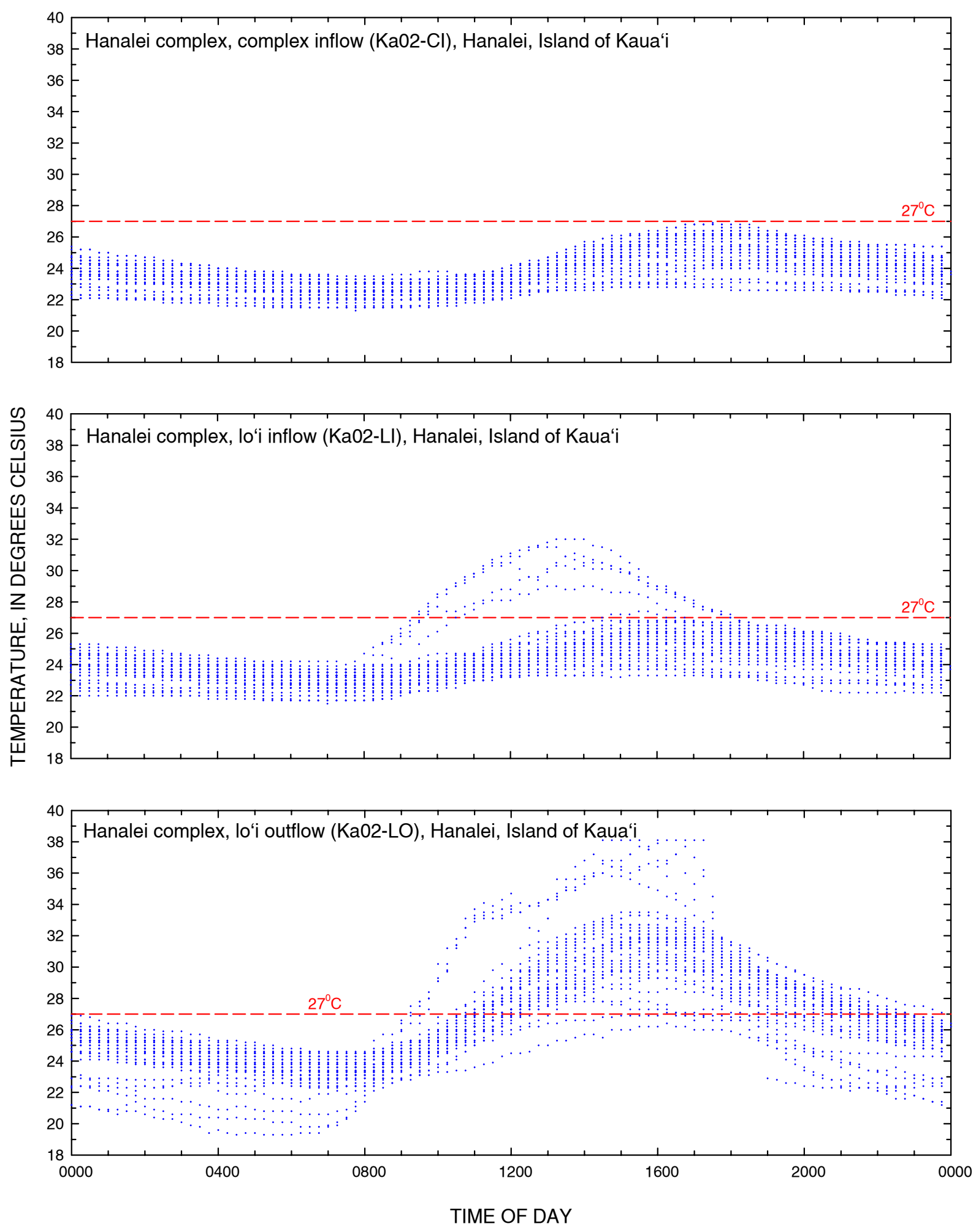

Figure 10. Daily pattern of water temperature in Hanalei lo'i complex, Island of Kaua'i. Plot shows all temperature data plotted against the time of day that each measurement was recorded. 


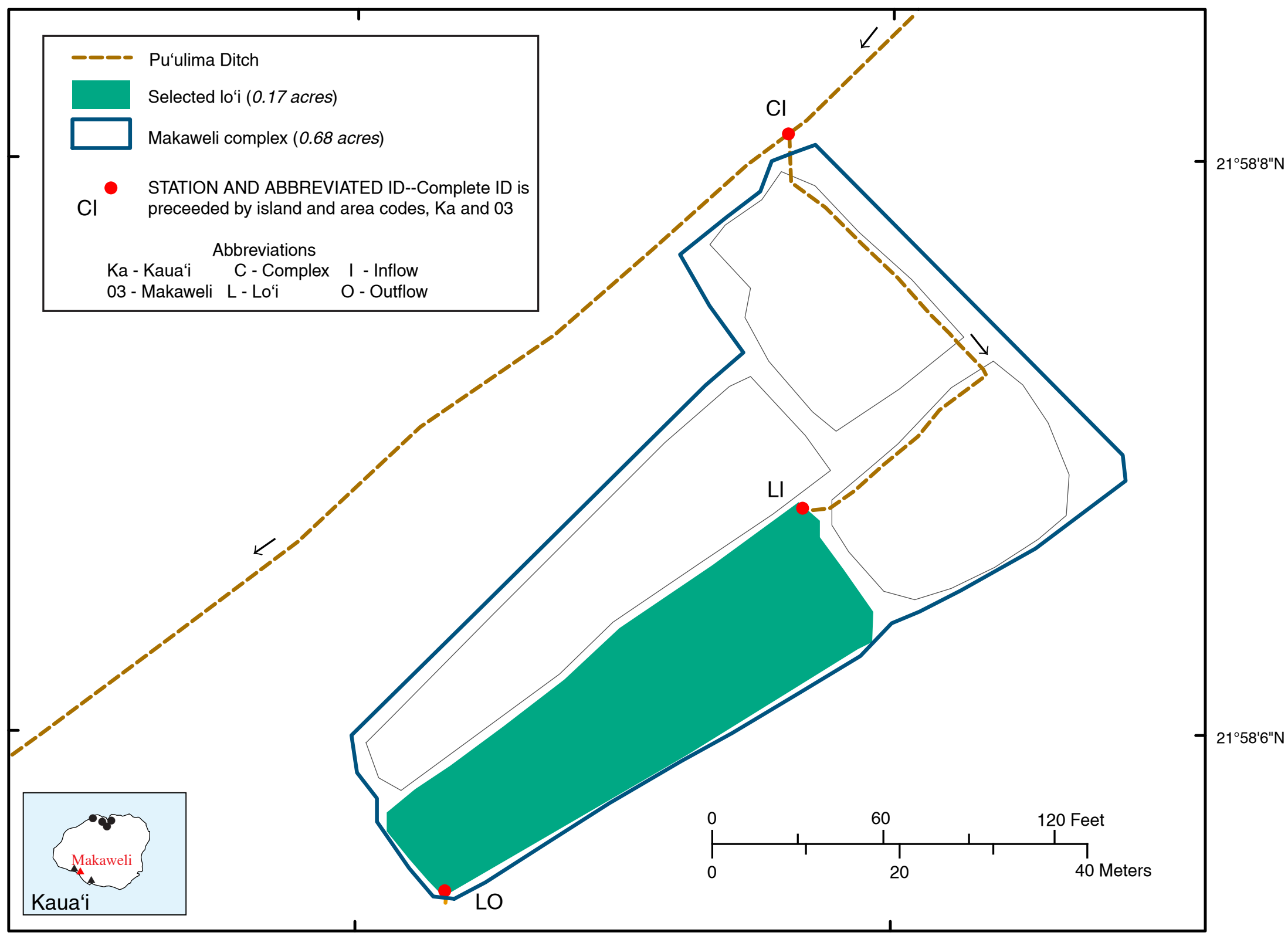

Figure 11. Makaweli lo'i complex, Island of Kaua'i. 

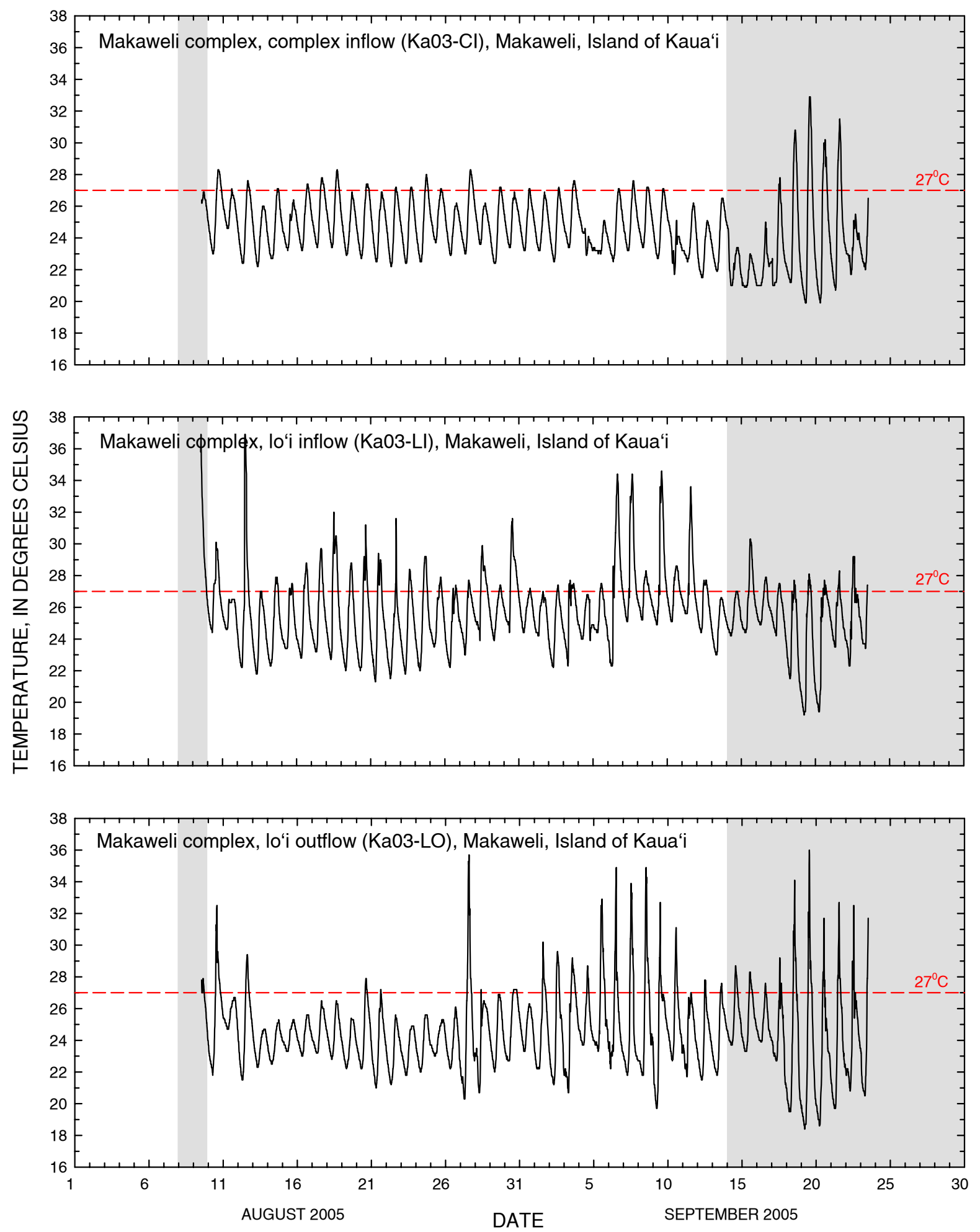

Highlighted periods indicate atypical irrigated conditions. On August 9, at the time of first visit, no flow was going into the selected lo'i. During September 14-15, a rainstorm deposited heavy debris upstream of the main diversion dam which significantly reduced flow in the 'auwai for the following period.

Figure 12. Water temperature in Makaweli lo'i complex, Island of Kaua'i. 

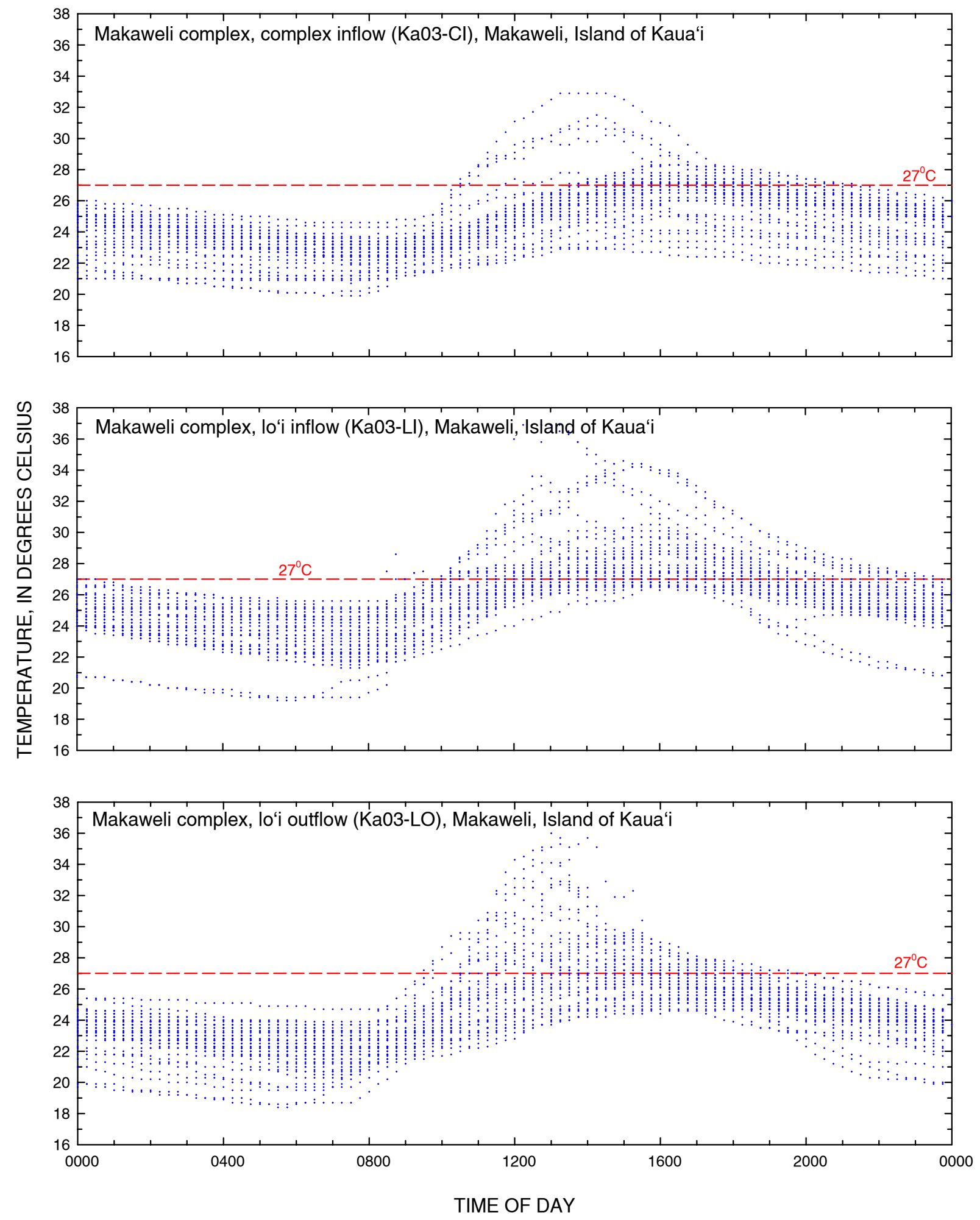

Figure 13. Daily pattern of water temperature in Makaweli lo'i complex, Island of Kaua'i. Plot shows all temperature data plotted against the time of day that each measurement was recorded. 


\section{O‘ahu}

Three areas were measured on $\mathrm{O}^{\text {‘ahu- }}$ Waiāhole and Waihe "e (windward sites) and Hale 'iwa (leeward site). Flow measurements were made in Waiahhole on August 15, 2005, when the temperature loggers were deployed, and on October 17, 2005, when the temperature loggers were removed (tables 4 and 5). The Waiāhole area is supplied through an unnamed 'auwai with water diverted from Waianu Stream (fig. 13). Two independent complexes were studied. Ten flow measurements were made, and seven temperature loggers were deployed at selected inflow and outflow locations (figs. 14 and 15).

Flow measurements were made in Waihe 'e on August 23, 2005, when the temperature loggers were deployed, and on October 18, 2005, when the temperature loggers were removed (tables 4 and 5). The Waihe"e area is supplied through the Waihe'e Ditch with water diverted far upstream from Waihe'e Stream (fig. 16). Two lo'i complexes were available for study in this area. Eight flow measurements were made, and four temperature loggers were deployed in the Waihe'e area (figs. 17 and 18).

The Hale "iwa area is supplied by ground water pumped from nearby springs and was considered to be one lo 'i complex for this study (fig. 19). No flow measurements were made because of difficulty finding places to make measurements, but the kalo farmer estimated the flow to be $1.08 \mathrm{Mgal} / \mathrm{d}$ (table 4). Three temperature loggers were deployed in the Hale 'iwa area from August 10, 2006, to September 26, 2006 (table 5; figs. 20 and 21). 
Table 4. Summary of discharge measurements and areas for selected lo'i complexes, Island of O'ahu.

[Mgal/d, million gallons per day; gad, gallons per acre per day; na, not applicable, average water use is determined by summing the averages of each complex or lo $i \mathrm{i}$ and dividing by the number of complexes or lo'i]

\begin{tabular}{|c|c|c|c|c|c|c|c|c|c|c|c|c|c|}
\hline \multirow[b]{2}{*}{$\begin{array}{l}\text { Geographic } \\
\text { designation }\end{array}$} & \multirow[b]{2}{*}{ Area } & \multicolumn{6}{|c|}{ Complex } & \multicolumn{6}{|c|}{ Lo'i } \\
\hline & & Station & $\begin{array}{c}\text { Irrigation } \\
\text { area } \\
\text { (acre) }\end{array}$ & Date & $\begin{array}{l}\text { Measurement } \\
\text { time }\end{array}$ & $\begin{array}{l}\text { Discharge } \\
\text { (Mgal/d) }\end{array}$ & $\begin{array}{l}\text { Water } \\
\text { use } \\
\text { (gad) }\end{array}$ & Station & $\begin{array}{c}\text { Irriga- } \\
\text { tion area } \\
\text { (acre) }\end{array}$ & Date & $\begin{array}{l}\text { Measure- } \\
\text { ment time }\end{array}$ & $\begin{array}{c}\text { Dis- } \\
\text { charge } \\
\text { (Mgal/d) }\end{array}$ & $\begin{array}{l}\text { Water } \\
\text { use } \\
\text { (gad) }\end{array}$ \\
\hline \multirow[t]{6}{*}{ Windward } & Waiãhole & $\mathrm{Oa} 04 \mathrm{~A}-\mathrm{CI}$ & 1.00 & $8 / 15 / 2005$ & 1019 & 0.35 & 350,000 & Oa04A-LI & 0.12 & $8 / 15 / 2005$ & 1045 & 0.080 & 660,000 \\
\hline & & & & $10 / 17 / 2005 a$ & 0932 & 0.25 & 250,000 & & & $10 / 17 / 2005$ & 1009 & 0.033 & 270,000 \\
\hline & & $\mathrm{Oa} 04 \mathrm{~B}-\mathrm{CI}$ & 0.71 & $8 / 15 / 2005$ & 1325 & 0.42 & 590,000 & Oa04B-LI & 0.12 & $8 / 15 / 2005$ & 1420 & 0.045 & 390,000 \\
\hline & & & & $10 / 17 / 2005 b$ & 1252 & 0.72 & $1,000,000$ & & & $10 / 17 / 2005$ & 1327 & 0.080 & 690,000 \\
\hline & & & & & & & & Oa04B-LO & & $8 / 15 / 2005$ & 1516 & 0.012 & na \\
\hline & & & & & & & & & & $10 / 17 / 2005$ & 1345 & 0.060 & na \\
\hline \multirow[t]{4}{*}{ Windward } & Waihe'e & $\mathrm{Oa} 05 \mathrm{~A}-\mathrm{CI}$ & 1.94 & $8 / 23 / 2005$ & 1340 & 0.59 & 300,000 & Oa05B-LI & 0.21 & $8 / 23 / 2005$ & 1258 & 0.11 & 520,000 \\
\hline & & & & $10 / 18 / 2005$ & 1439 & 0.52 & 270,000 & & & $10 / 18 / 2005$ & 1047 & 0.047 & 230,000 \\
\hline & & $\mathrm{Oa} 05 \mathrm{~B}-\mathrm{CI}$ & 1.02 & $8 / 23 / 2005$ & 1318 & 0.15 & 150,000 & Oa05B-LO & & $8 / 23 / 2005$ & 1204 & 0.047 & na \\
\hline & & & & $10 / 18 / 2005$ & 1021 & 0.12 & 120,000 & & & $10 / 18 / 2005$ & 1604 & 0.030 & na \\
\hline Leeward & Hale'iwa & Oa06-CI & 25.14 & na & na & $1.08 \mathrm{c}$ & 44,000 & Oa06-LI & 0.70 & 9/26/2006 & 1023 & 0.15 & 210,000 \\
\hline number & & & 5 & & & & 5 & & 4 & & & & 4 \\
\hline minimum & & & 0.71 & & & & 44,000 & & 0.12 & & & & 210,000 \\
\hline maximum & & & 25.14 & & & & $1,000,000$ & & 0.70 & & & & 690,000 \\
\hline average & & & 1.17 & & & & 310,000 & & 0.29 & & & & 400,000 \\
\hline
\end{tabular}

a'auwai overflow upstream of measurement site resulting from backwater conditions caused by debris in the 'auwai; reason for lower flow.

b'auwai had just been cleaned; reason for higher flow.

'Estimated pumping rate of $750 \mathrm{gal} / \mathrm{min}$ (by farmer) from nearby spring to irrigate lo'i complexes 
Table 5. Water-temperature statistics based on measurements collected at 15 -minute intervals for lo'i complexes on the Island of O'ahu.

[ ${ }^{\circ} \mathrm{C}$, degrees Celsius; na, not applicable]

\begin{tabular}{|c|c|c|c|c|c|c|c|c|c|c|c|c|}
\hline \multirow{3}{*}{$\begin{array}{l}\text { Geographic } \\
\text { designation }\end{array}$} & \multirow{3}{*}{$\begin{array}{c}\text { Area } \\
\text { Waiãhole }\end{array}$} & \multirow{3}{*}{$\begin{array}{l}\text { Station } \\
\text { Oa04A-CI }\end{array}$} & \multirow{2}{*}{ Period of record } & \multicolumn{3}{|c|}{ Temperature ( $\left.{ }^{\circ} \mathrm{C}\right)$} & \multirow{2}{*}{\multicolumn{3}{|c|}{$\begin{array}{c}\text { Range of times daily } \\
\text { peak temperatures } \\
\text { occurred }\end{array}$}} & \multicolumn{3}{|c|}{$\begin{array}{c}\text { Temperature measurements } \\
\text { greater than } 27^{\circ} \mathrm{C}\end{array}$} \\
\hline & & & & \multirow{2}{*}{$\begin{array}{c}\text { Mean } \\
21.4\end{array}$} & Range & \multirow{2}{*}{$\begin{array}{c}\text { Mean daily range } \\
1.4\end{array}$} & & & & \multirow{2}{*}{$\begin{array}{c}\text { Percent } \\
0.0\end{array}$} & \multirow{2}{*}{$\begin{array}{c}\begin{array}{c}\text { Earliest time } \\
\text { of day }\end{array} \\
\text { na }\end{array}$} & \multirow{2}{*}{$\begin{array}{c}\begin{array}{c}\text { Latest time } \\
\text { of day }\end{array} \\
\text { na }\end{array}$} \\
\hline & & & $8 / 15 / 2005-10 / 17 / 2005$ & & $20.5-23.3$ & & 1030 & - & 2345 & & & \\
\hline & & Oa04A-LI & $8 / 15 / 2005-10 / 17 / 2005$ & 21.5 & $20.4-23.4$ & 1.5 & 0945 & - & 2345 & 0.0 & 0000 & 0000 \\
\hline & & Oa04A-LO & $8 / 15 / 2005-10 / 17 / 2005$ & 24.6 & $20.8-35.7$ & 8.5 & 1100 & - & 1730 & 21.6 & 1030 & 1845 \\
\hline & & $\mathrm{Oa} 04 \mathrm{~B}-\mathrm{CI}$ & $8 / 15 / 2005-10 / 17 / 2005$ & 21.7 & $20.5-24.2$ & 1.5 & 1100 & - & 2345 & 0.0 & 0000 & 0000 \\
\hline & & Oa04B-LI & $8 / 15 / 2005-10 / 17 / 2005$ & 21.9 & $20.5-24.5$ & 1.7 & 1100 & - & 1730 & 0.0 & na & na \\
\hline & & Oa04B-LO & $8 / 15 / 2005-10 / 17 / 2005$ & 24.5 & $20.5-35.3$ & 7.6 & 1015 & - & 1530 & 21.4 & 0915 & 1915 \\
\hline & & & $8 / 15 / 2005-10 / 17 / 2005$ & 23.0 & $20.5-29.7$ & 4.1 & 1045 & - & 1600 & 2.5 & 1130 & 1645 \\
\hline \multirow[t]{4}{*}{ Windward } & Waihe'e & Oa05A-CI & $8 / 23 / 2005-10 / 18 / 2005$ & 21.6 & $20.7-22.7$ & 0.7 & 1045 & - & 2345 & 0.0 & 0000 & 0000 \\
\hline & & Oa05B-CI & $8 / 23 / 2005-10 / 18 / 2005$ & 21.8 & $20.7-23.9$ & 1.2 & 1030 & - & 1545 & 0.0 & 0000 & 0000 \\
\hline & & Oa05B-LI & $8 / 23 / 2005-10 / 18 / 2005$ & 22.0 & $20.7-24.9$ & 1.5 & 1030 & - & 1500 & 0.0 & 0000 & 0000 \\
\hline & & Oa05B-LO & $8 / 23 / 2005-10 / 18 / 2005$ & 25.0 & $21.4-35.3$ & 4.9 & 1030 & - & 1700 & 22.3 & 0900 & 2200 \\
\hline & & & & & & & & & & & & \\
\hline \multirow[t]{3}{*}{ Leeward } & Hale'iwa & Oa06-CI & $8 / 10 / 2006-9 / 26 / 2006$ & 23.2 & $22.6-24.2$ & 0.7 & 0700 & - & 1800 & 0.0 & na & na \\
\hline & & Oa06-LI & $8 / 10 / 2006-9 / 26 / 2006$ & 25.2 & $21.7-31.0$ & 4.1 & 0930 & - & 1830 & 23.2 & 1100 & 2145 \\
\hline & & Oa06-L & $8 / 10 / 2006-9 / 26 / 2006$ & 26.3 & $21.9-35.1$ & 5.4 & 1315 & - & 1730 & 34.5 & 1000 & 2215 \\
\hline
\end{tabular}




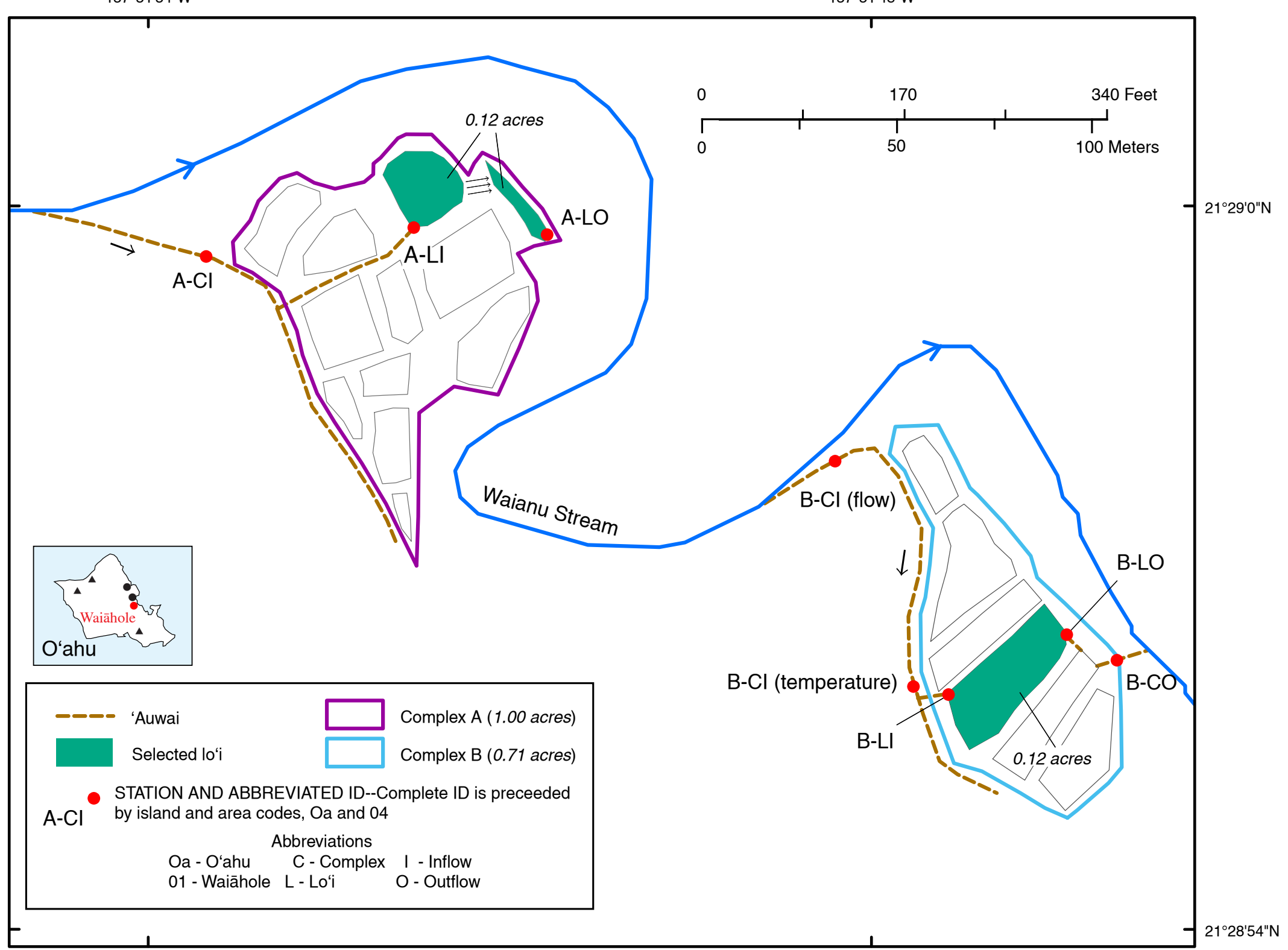

Figure 14. Waiāhole lo'i complexes, Island of O‘ahu. 

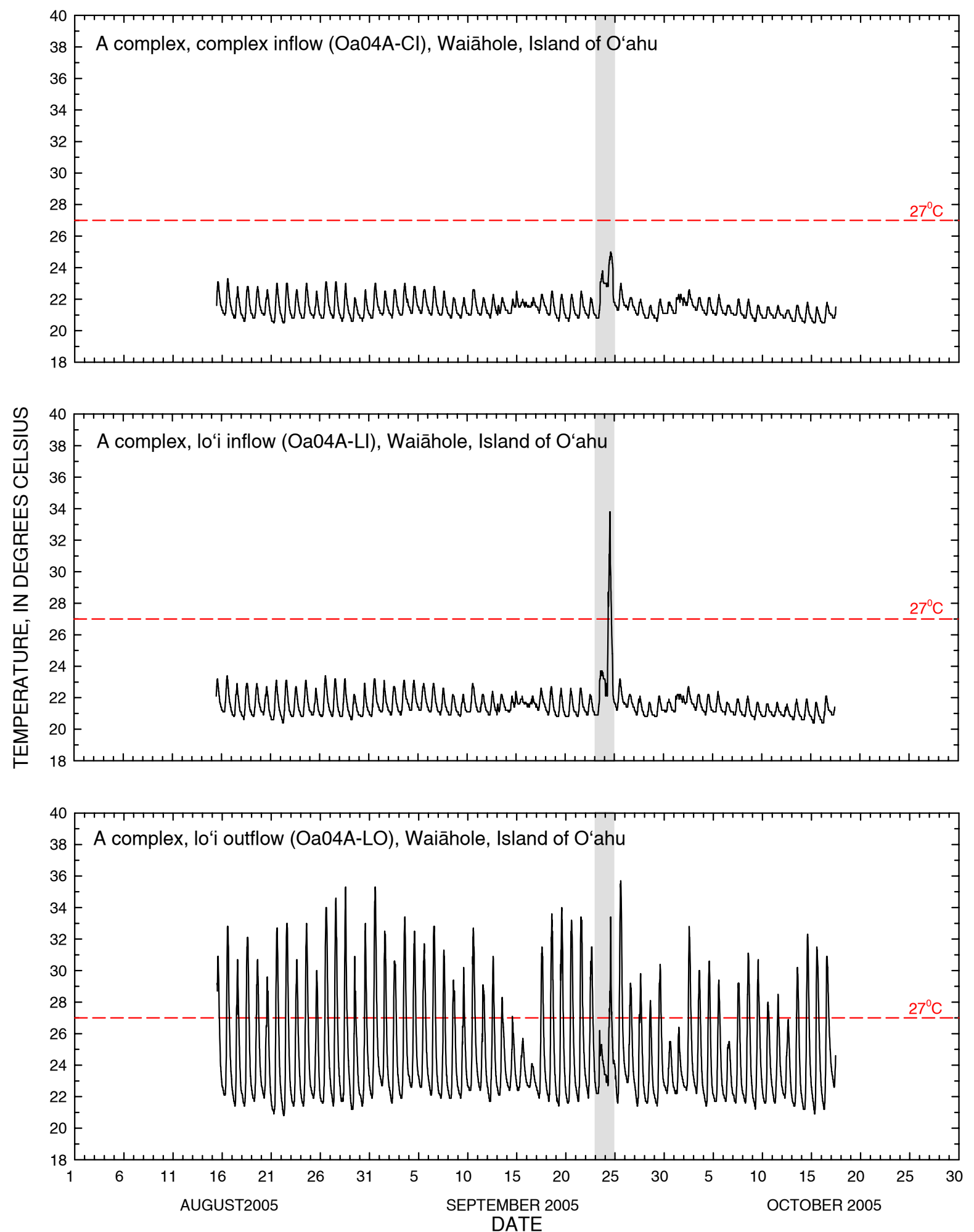

Highlighted periods indicate atypical irrigated conditions. On September 23, a heavy rainstorm flooded the complex and deposited debris around diversion dam and 'auwai which significantly reduced inflow on the following day and caused the water temperature to rise.

Figure 15. Water temperature in Waiāhole lo'i complexes, Island of O'ahu. 

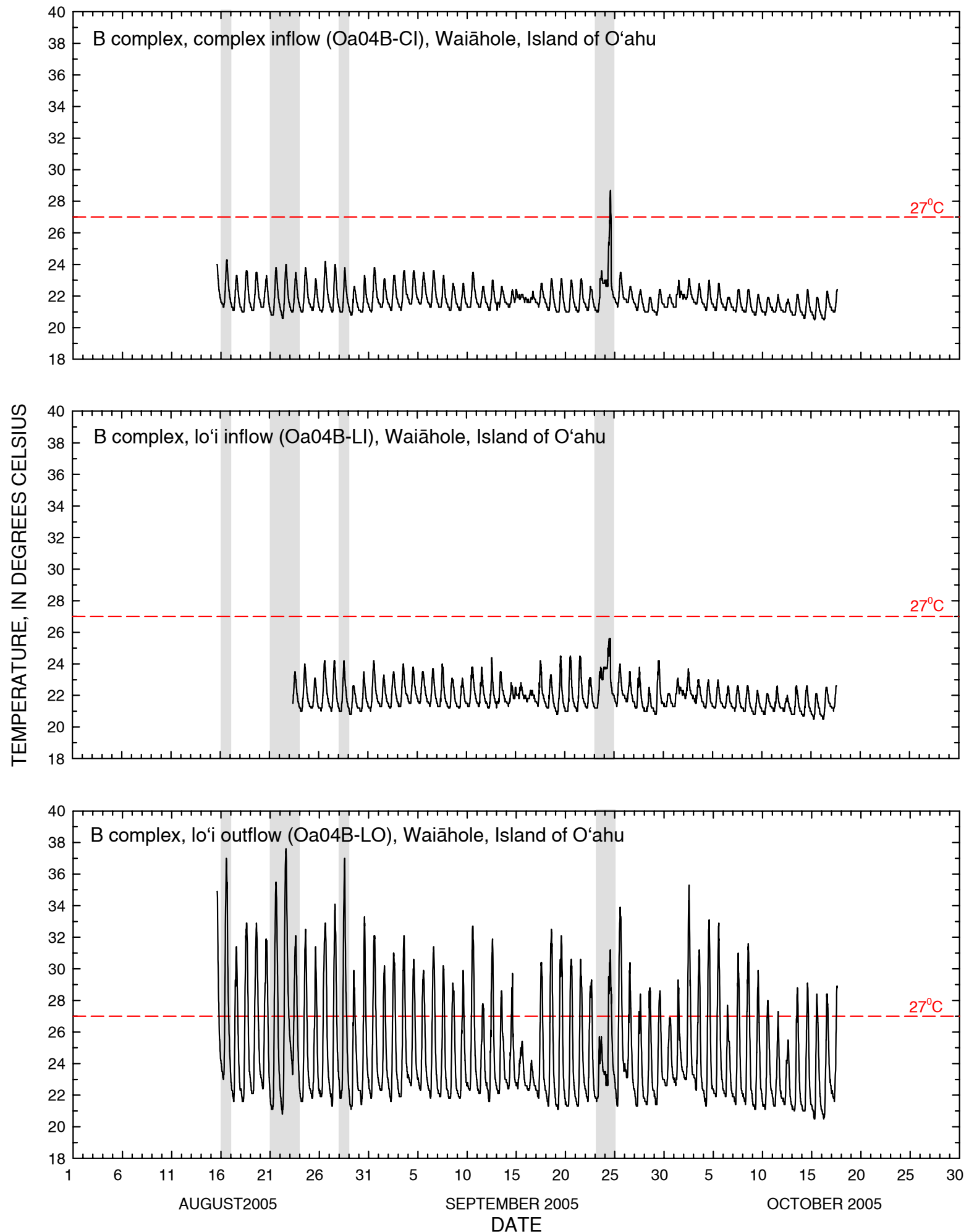

Highlighted periods indicate atypical irrigated conditions. On August 16, 21-23, farmer noted that intake pipe to the selected lo'i was shut off for weeding. On August 28, field inflow was lower than normal. On September 23, heavy rainstorm flooded the complex and deposited debris around diversion dam and 'auwai which significantly reduced inflow on the following day and caused water temperature to rise.

Figure 15. Continued. 


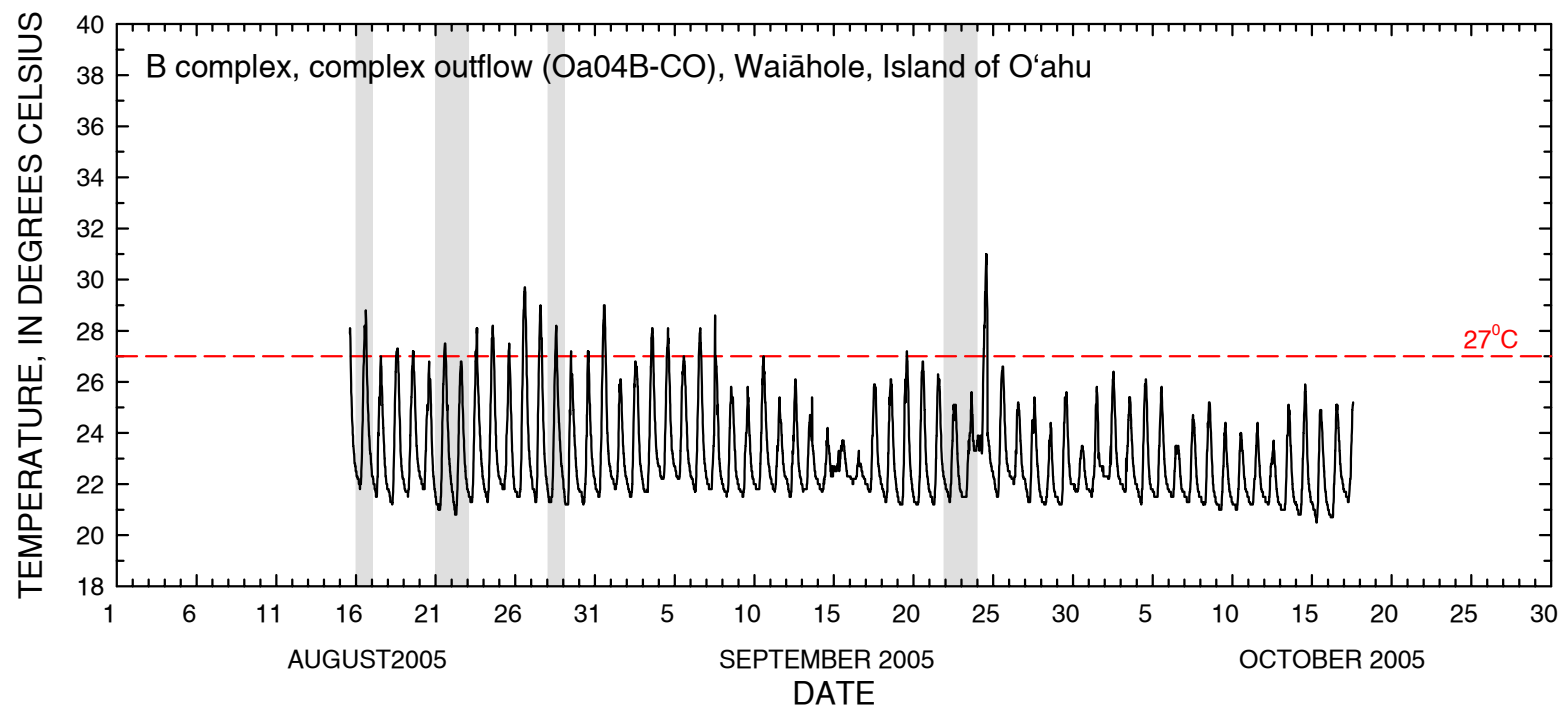

Highlighted periods indicate atypical irrigated conditions. On August 16, 21-23, farmer noted that intake pipe to the selected lo'i was shut off for weeding. On August 28, field inflow was lower than normal. On

September 23, heavy rainstorm flooded the complex and deposited debris around diversion dam and 'auwai which significantly reduced inflow on the following day and caused water temperature to rise.

Figure 15. Continued. 

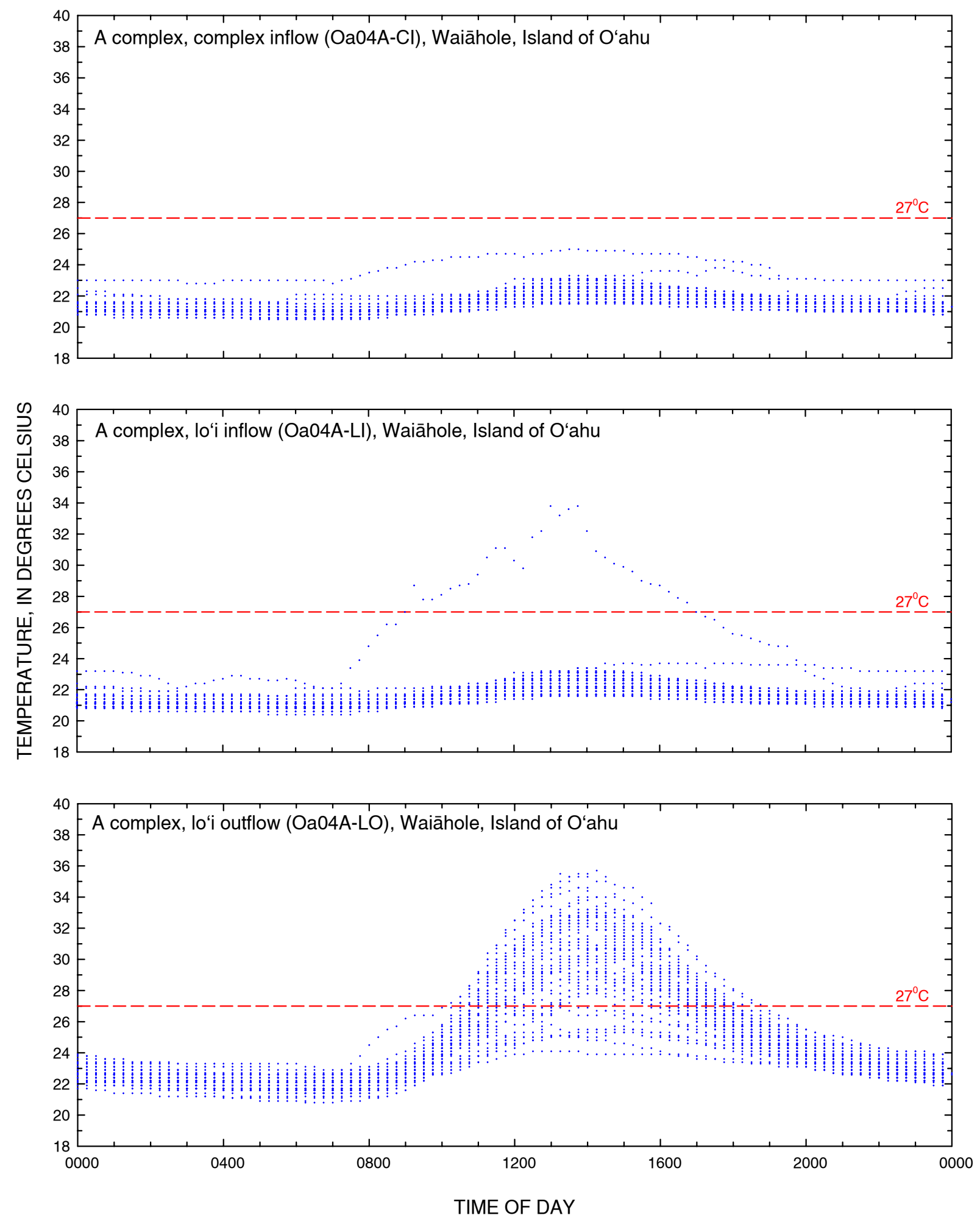

Figure 16. Daily pattern of water temperature in Waiāhole lo'i complexes, Island of O'ahu. 

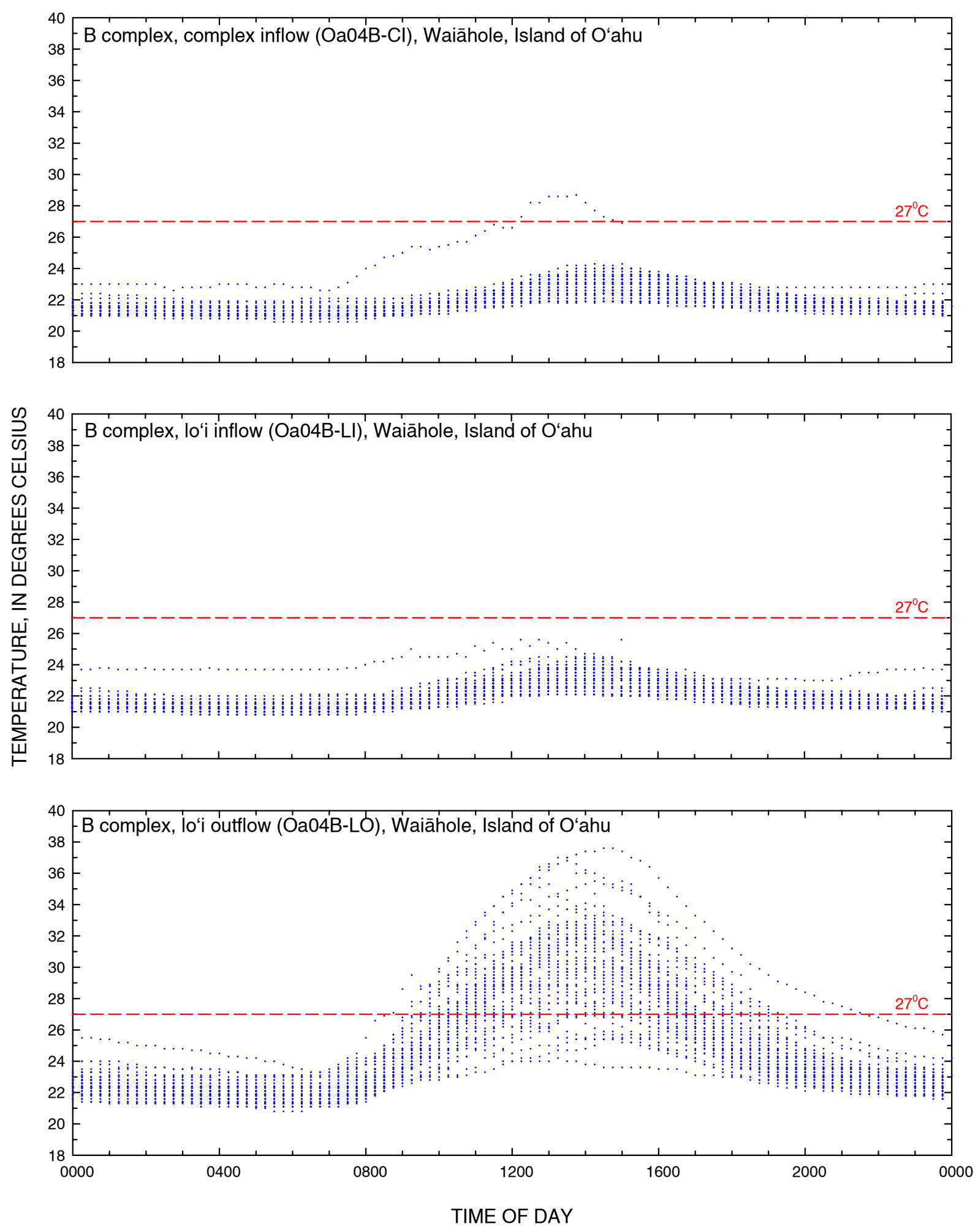

Figure 16. Continued. 


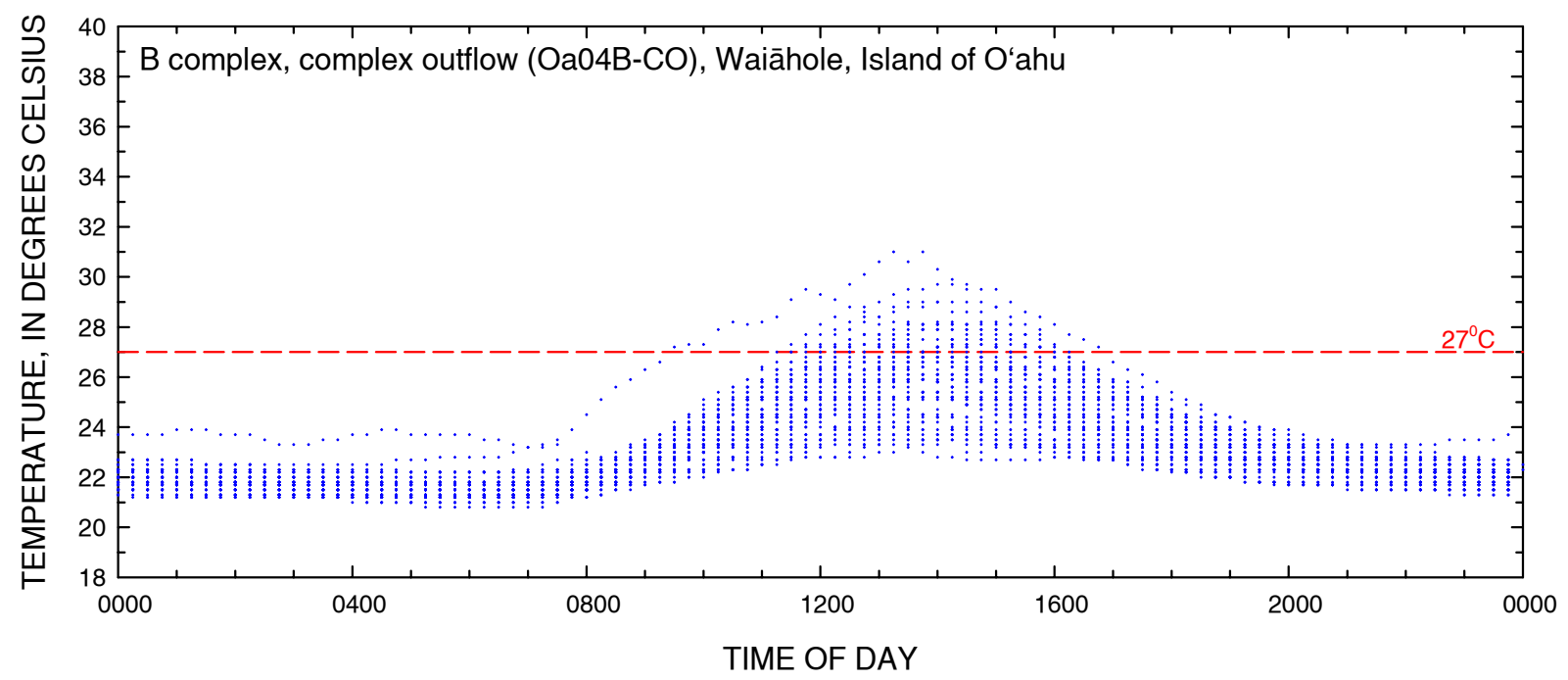

Figure 16. Continued. 


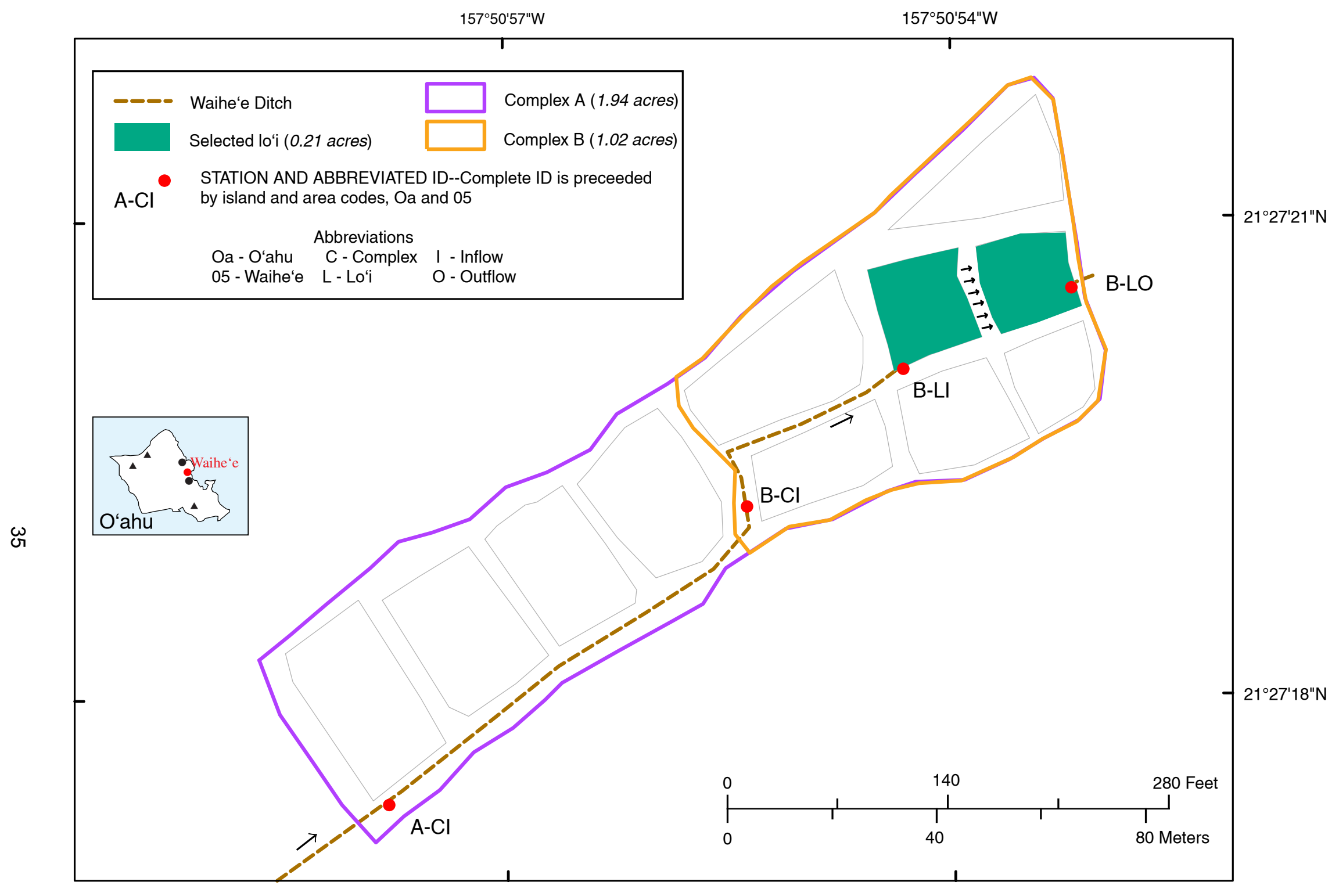

Figure 17. Waihe'e lo'i complex, Island of O'ahu. 


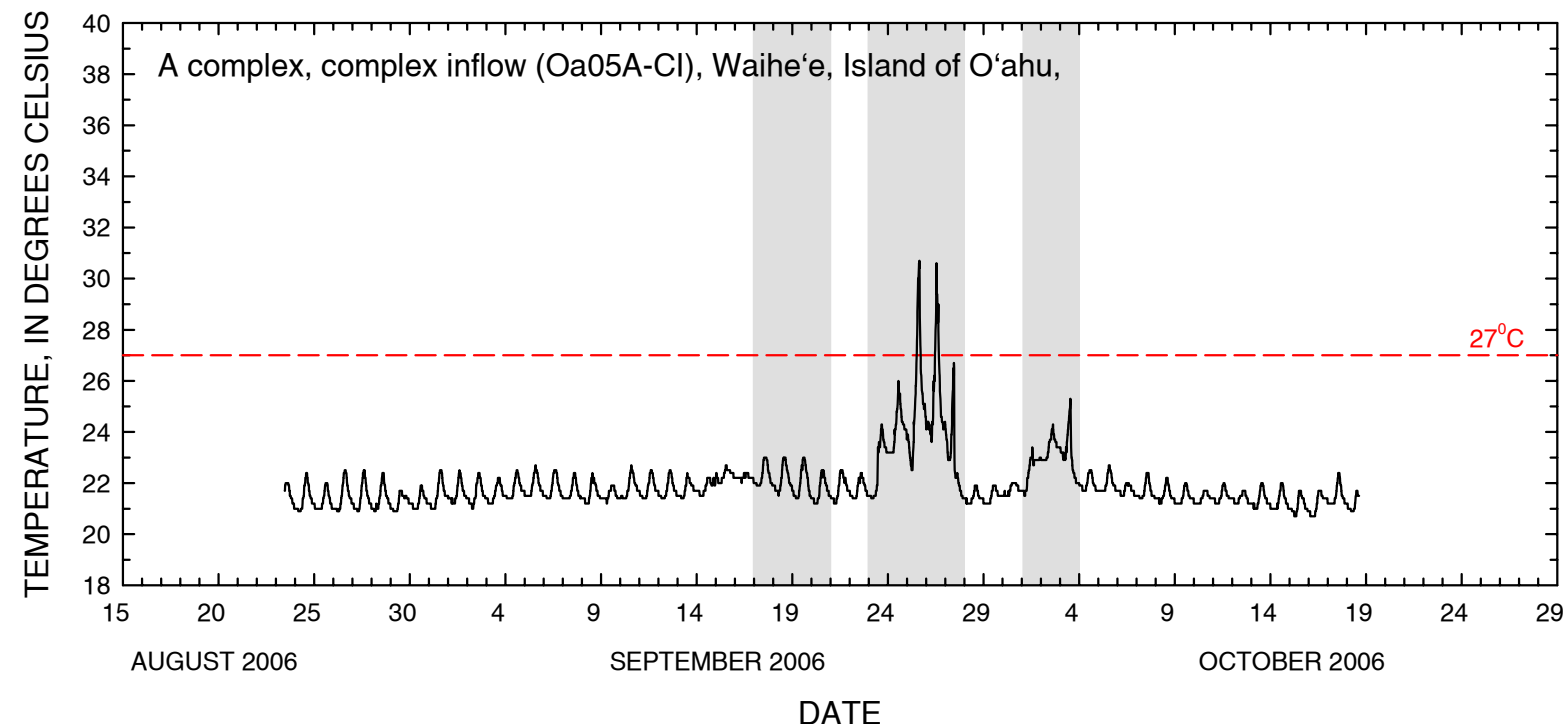

Highlighted periods indicate atypical irrigated conditions. Heavy rain, prior to September 17-20, probably clogged intake and reduced flow to complex which caused the rise in water temperatures. On September 23, heavy rainstorm flooded the complex and deposited debris to upstream diversion dam and 'auwai which significantly reduced inflow to complex and caused water temperatures to rise. During October 1-4, upstream diversion dam was being repaired which probably caused the reduction in flow and rise in water temperatures.

Figure 18. Water temperature in Waihe'e lo'i complexes, Island of O'ahu. 

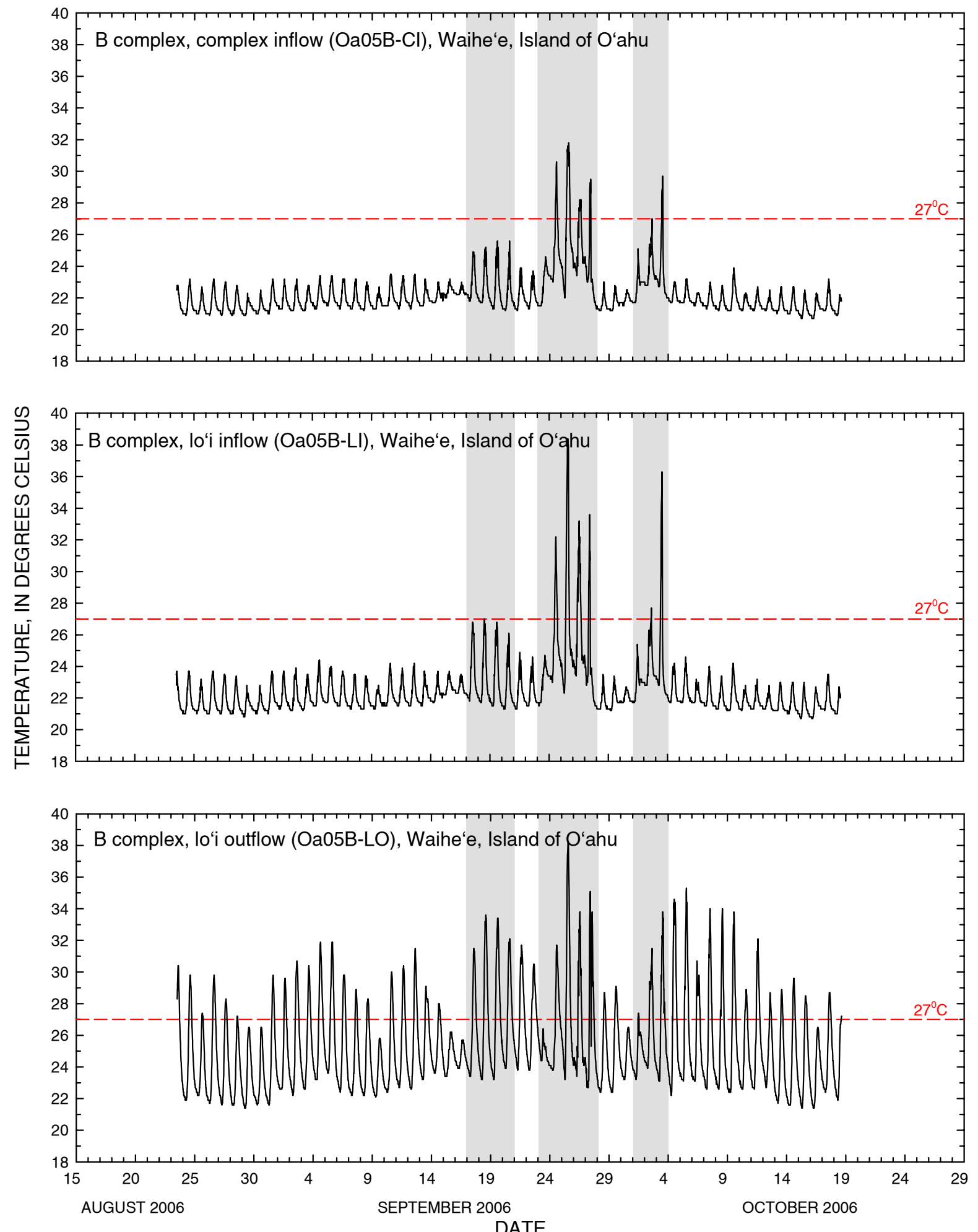

Highlighted periods indicate atypical irrigated conditions. Heavy rain, prior to September 17-20, probably clogged intake and reduced flow to complex which caused the rise in water temperatures. On September 23, heavy rainstorm flooded the complex and deposited debris to upstream diversion dam and 'auwai which significantly reduced inflow to complex and caused water temperatures to rise. During October 1-4, upstream diversion dam was being repaired which probably caused the reduction in flow and rise in water temperatures.

Figure 18. Continued. 


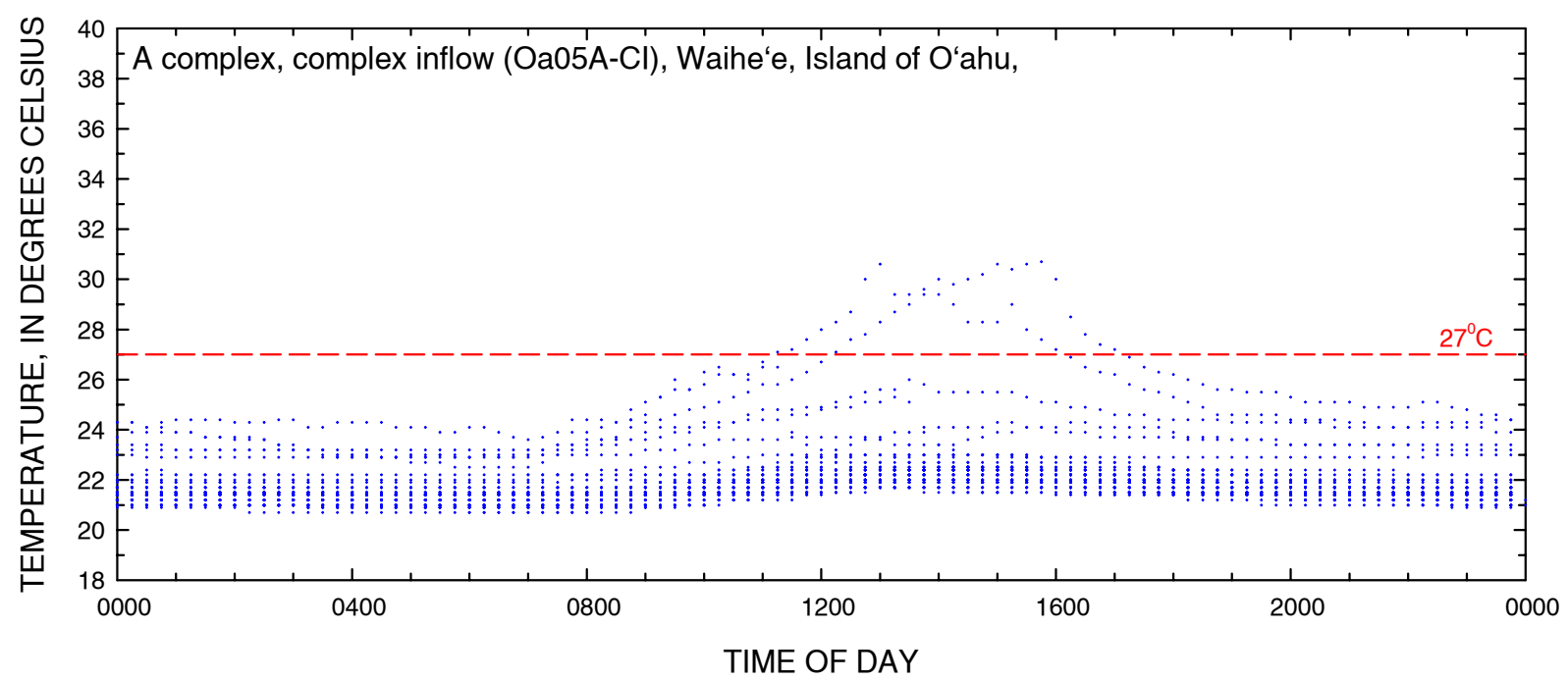

Figure 19. Daily pattern of water temperature in Waihe'e lo'i complex, Island of O'ahu. Plot shows all temperature data plotted against the time of day that each measurement was recorded. 

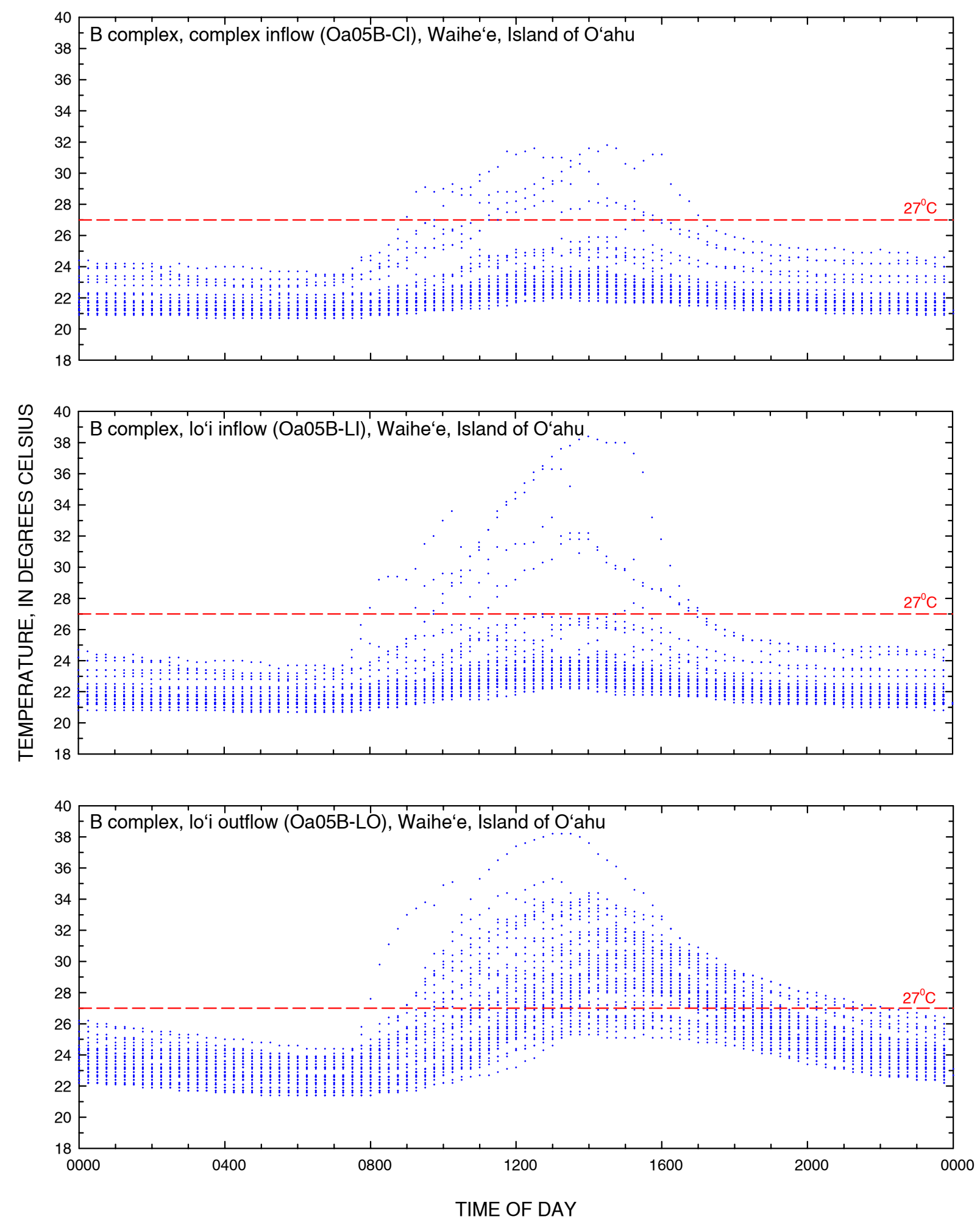

Figure 19. Continued. 
$158^{\circ} 6^{\prime} 19^{\prime \prime} \mathrm{W}$

$158^{\circ} 6^{\prime} 4^{\prime \prime} \mathrm{W}$

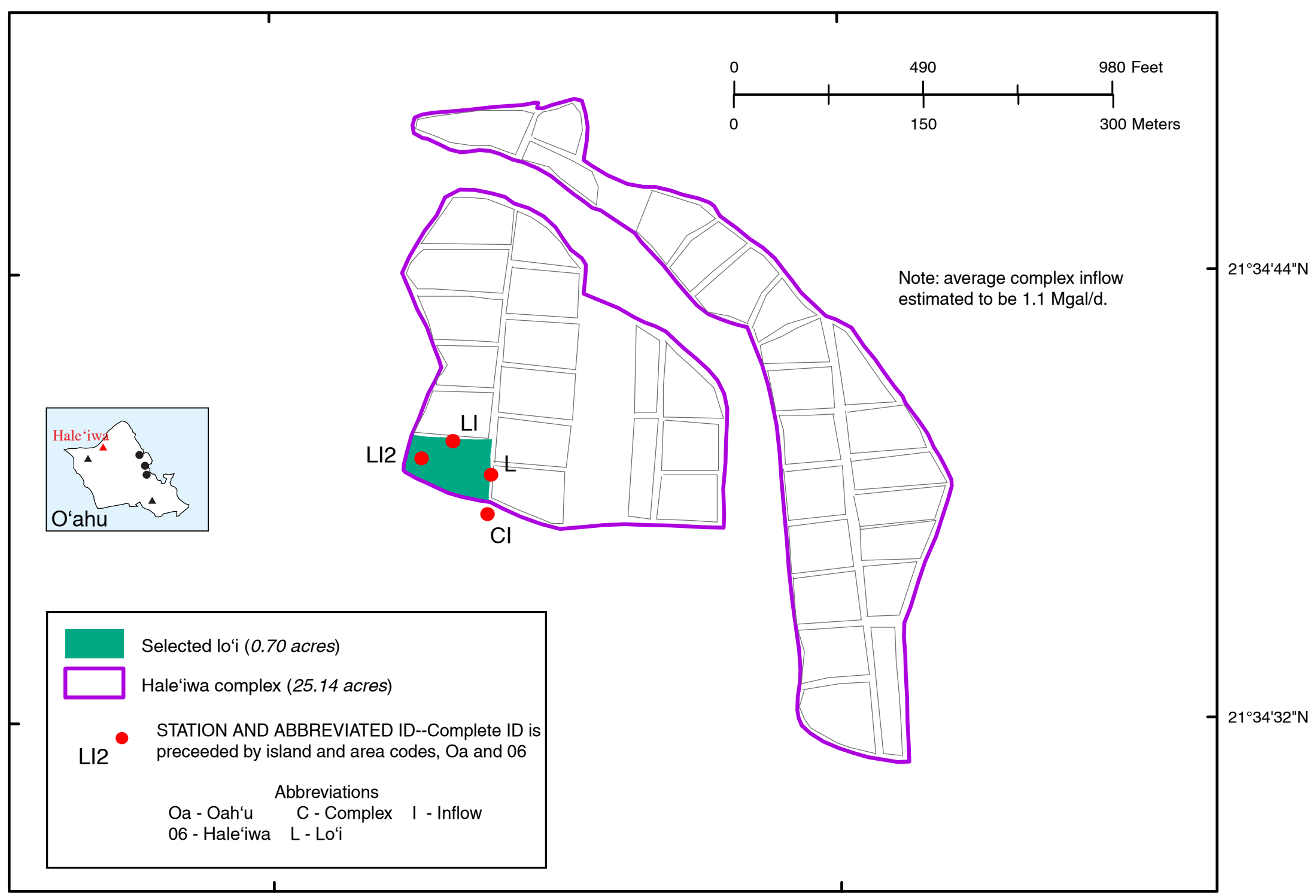

Figure 20. Hale'iwa lo'i complex, Island of O‘ahu. 

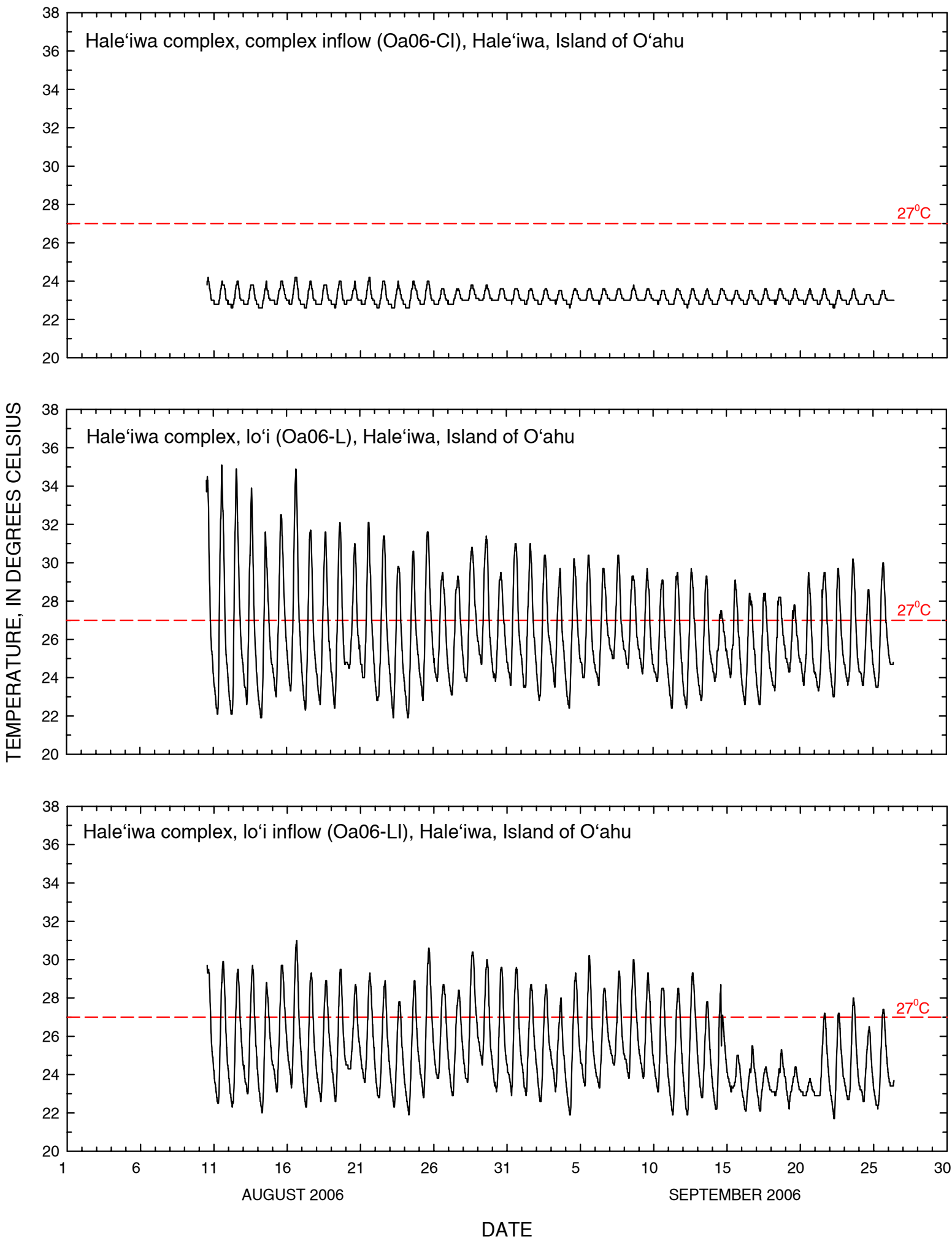

Figure 21. Water temperature in Hale'iwa lo'i complexes, Island of O‘ahu. 

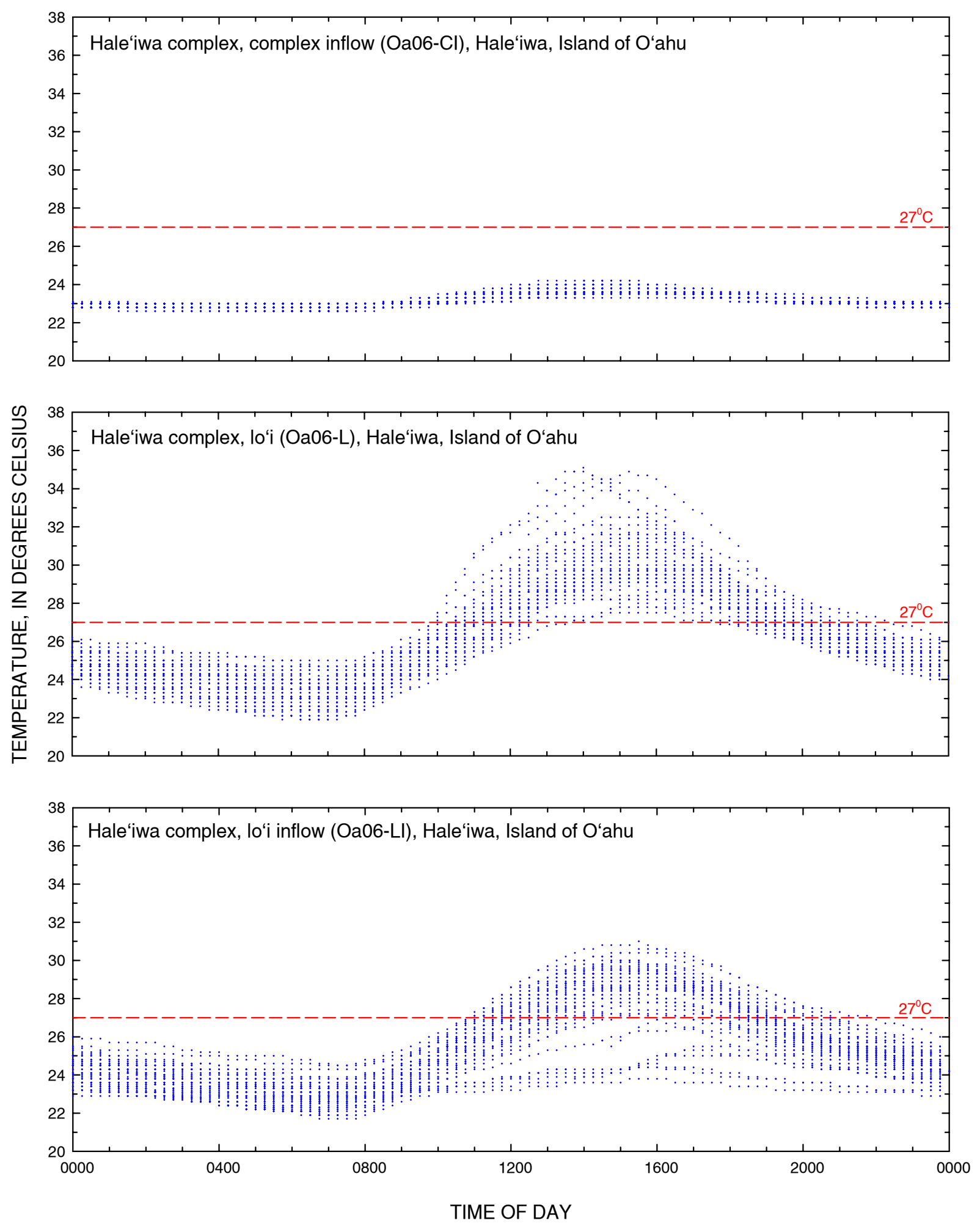

Figure 22. Daily pattern of water temperature in Hale'iwa lo'i complex, Island of O'ahu. Plot shows all temperature data plotted against the time of day that each measurement was recorded. 


\section{Maui}

Three areas were measured on Maui-Waihe'e, Wailua, and $\mathrm{Ke}$ 'anae, all windward sites. Flow measurements were made July 29-31, 2006, when the temperature loggers were deployed, and September 21-22, 2006, when the temperature loggers were removed (tables 6 and 7). The Waihe'e area gets water through an 'auwai supplied by Spreckel's Ditch with water diverted from the Waihe "e River (fig. 22). The Waihe'e area was considered to be two lo'i complexes (an upper and a lower complex), both of which were studied. Eight flow measurements were made, and three temperature loggers were deployed at selected inflow and outflow locations (figs. 23 and 24).

The Wailua area contains numerous lo ' $\mathrm{i}$ complexes, three of which were available for study_Lakini, Wailua, and Waikani. The Lakini lo 'i complex is supplied through an 'auwai with water diverted from Hamau Stream. Hamau Stream receives diverted water from Waiokomilo Stream further upstream (fig. 25). The Lakini area was considered to be one lo' $i$ complex in this study. Eight flow measurements were made, and two temperature loggers were deployed in the Lakini area (figs. 26 and 27). In addition to the five flow measurements made to determine flow directly into the complex, two measurements were made in the 'auwai upstream of all lo' $i$ complexes to determine the amount of flow available for all downstream lo ' $i$ complexes (July 30, 2006, 2.31 Mgal/d and September 21, 2006, 1.37 Mgal/d), and one measurement was made in Hamau Stream (NWIS link) downstream of the 'auwai diversion to determine how much water remained in the stream (July 30, 2006, $0.54 \mathrm{Mgal} / \mathrm{d})$.

The lo 'i complex named Wailua in this study is supplied through an 'auwai with water diverted from Waiokomilo Stream (fig. 28). Two flow measurements were made, and one temperature logger was deployed in the Wailua area (figs. 29 and 30).

The Waikani area is supplied through an 'auwai with water diverted from Wailuanui Stream (fig. 31). Two flow measurements were made, and two temperature loggers were deployed in the Waikani area (figs. 32 and 33).

The Ke'anae area has numerous lo'i and all active 10 ' $i$ were treated as one lo $i \mathrm{i}$ complex supplied by the Ke'anae Flume, which diverts water from Pālauhulu Stream (fig. 34). Two flow measurements were made, and two temperature loggers were

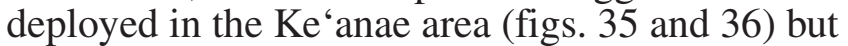
the lo' $i$ complex outlet temperature logger (Ma12$\mathrm{CO})$ failed to collect data during the deployment. Flow measurements were made near the flume intake at the site of a former USGS streamflow gaging station (Taro patch feeder ditch at $\mathrm{Ke}^{\text {'anae, }}$ Maui, station 16522000) where the median flow from 1934 to 1968 was $2.2 \mathrm{Mgal} / \mathrm{d}$. 
Table 6. Summary of discharge measurements and areas for selected lo'i complexes, Island of Maui.

[Mgal/d, million gallons per day; gad, gallons per acre per day; na, not applicable; average water use is determined by summing the averages of each complex or lo'i and dividing by the number of complexes or lo'i]

\begin{tabular}{|c|c|c|c|c|c|c|c|c|}
\hline \multirow[b]{2}{*}{$\begin{array}{l}\text { Geographic } \\
\text { designation }\end{array}$} & \multirow[b]{2}{*}{ Area } & \multicolumn{6}{|c|}{ Complex } & \multirow[b]{2}{*}{ Remarks } \\
\hline & & Station & $\begin{array}{c}\text { Irrigation } \\
\text { area } \\
\text { (acre) }\end{array}$ & Date & $\begin{array}{l}\text { Measurement } \\
\text { time }\end{array}$ & $\begin{array}{l}\text { Discharge } \\
\text { (Mgal/d) }\end{array}$ & $\begin{array}{l}\text { Water use } \\
\quad \text { (gad) }\end{array}$ & \\
\hline \multirow[t]{8}{*}{ Windward } & Waihe'e & Ma08A-CI & 2.30 & $7 / 29 / 2006$ & 1501 & 0.34 & 150,000 & total flow for upper and lower complexes \\
\hline & & & & $9 / 22 / 2006$ & 1158 & 0.30 & 130,000 & total flow for upper and lower complexes \\
\hline & & Ma08B-CIR & na & $7 / 29 / 2006$ & 1500 & 0.025 & & \\
\hline & & Ma08B-CIL & na & & & 0.060 & & \\
\hline & & & 0.76 & & na & 0.085 & 110,000 & combined right and left complex inflows \\
\hline & & Ma08B-CIR & na & $9 / 22 / 2006$ & 1150 & 0.058 & & \\
\hline & & Ma08B-CIL & na & & 1055 & 0.067 & & \\
\hline & & & 0.76 & & na & 0.13 & 160,000 & combined right and left complex inflows \\
\hline \multirow[t]{7}{*}{ Windward } & Wailua (Lakini) & Ma09-CIR & na & $7 / 30 / 2006$ & 1004 & 0.26 & & \\
\hline & & Ma09-CIL & na & & 0947 & 0.30 & & \\
\hline & & & 0.74 & & na & 0.56 & 750,000 & combined right and left complex inflows \\
\hline & & Ma09-CIR & na & $9 / 21 / 2006$ & 1015 & 0.16 & & \\
\hline & & Ma09-CIL & na & & 1049 & 0.058 & & \\
\hline & & Ma09-CIM & na & & 1206 & 0.19 & & \\
\hline & & & 0.74 & & na & 0.41 & 550,000 & combined right, left, and middle complex inflows \\
\hline \multirow[t]{2}{*}{ Windward } & Wailua & Ma10-CI & 3.32 & $7 / 30 / 2006$ & 1136 & 0.59 & 180,000 & \\
\hline & & & & $9 / 21 / 2006$ & 0845 & 0.46 & 140,000 & \\
\hline \multirow[t]{2}{*}{ Windward } & Wailua (Waikani) & Ma11-CI & 2.80 & $7 / 30 / 2006$ & 1236 & 0.54 & 190,000 & \\
\hline & & & & $9 / 21 / 2006$ & 1608 & 0.26 & 93,000 & \\
\hline \multirow[t]{2}{*}{ Windward } & $\mathrm{Ke}^{\prime}$ anae & Ma12-CI & 10.53 & $7 / 31 / 2006$ & 0836 & 1.9 & 180,000 & $\begin{array}{l}\text { former U.S. Geological Survey streamflow-gaging } \\
\text { station }\end{array}$ \\
\hline & & & & $9 / 21 / 2006$ & 1415 & 1.6 & 150,000 & \\
\hline number & & & 6 & & & & 6 & \\
\hline minimum & & & 0.74 & & & & 93,000 & \\
\hline maximum & & & 10.53 & & & & 750,000 & \\
\hline average & & & 3.41 & & & & 230,000 & \\
\hline
\end{tabular}


Table 7. Water-temperature statistics based on measurements collected at 15-minute intervals for lo'i complexes on the Island of Maui.

$\left[{ }^{\circ} \mathrm{C}\right.$, degrees Celsius; na, not applicable]

\begin{tabular}{|c|c|c|c|c|c|c|c|c|c|c|c|c|}
\hline \multirow{3}{*}{$\begin{array}{l}\text { Geographic } \\
\text { designation }\end{array}$} & \multirow{3}{*}{$\begin{array}{c}\text { Area } \\
\text { Waihe'e }\end{array}$} & \multirow{3}{*}{$\begin{array}{l}\text { Station } \\
\text { Ma08A-CI }\end{array}$} & \multirow{3}{*}{$\begin{array}{c}\text { Period of record } \\
7 / 29 / 2006-9 / 22 / 2006\end{array}$} & \multicolumn{3}{|c|}{ Temperature $\left({ }^{\circ} \mathrm{C}\right)$} & \multirow{2}{*}{\multicolumn{3}{|c|}{$\begin{array}{c}\text { Range of times daily } \\
\text { - peak temperatures } \\
\text { occurred }\end{array}$}} & \multicolumn{3}{|c|}{$\begin{array}{c}\text { Temperature measurements } \\
\text { greater than } 27^{\circ} \mathrm{C}\end{array}$} \\
\hline & & & & \multirow{2}{*}{$\begin{array}{c}\text { Mean } \\
21.6\end{array}$} & \multirow{2}{*}{$\begin{array}{c}\text { Range } \\
9.9-24.0\end{array}$} & \multirow{2}{*}{$\begin{array}{c}\text { Mean daily } \\
\text { range }\end{array}$} & & & & \multirow{2}{*}{ Percent } & \multirow{2}{*}{$\begin{array}{c}\begin{array}{c}\text { Earliest time } \\
\text { of day }\end{array} \\
\text { na }\end{array}$} & \multirow{2}{*}{$\begin{array}{c}\text { Latest time } \\
\text { of day } \\
\text { na }\end{array}$} \\
\hline & & & & & & & 1015 & - & 1845 & & & \\
\hline & & Ma08B-CIL & $7 / 29 / 2006-9 / 22 / 2006$ & 24.9 & $20.3-34.0$ & 7.6 & 1130 & - & 1615 & 25.4 & 0930 & 1915 \\
\hline & & Ma08B-CO & $7 / 29 / 2006-9 / 22 / 2006$ & 25.5 & $20.0-35.5$ & 5.7 & 1115 & - & 1645 & 27.0 & 0945 & 2115 \\
\hline \multirow[t]{2}{*}{ Windward } & Wailua (Lakini) & Ma09-CIT & $7 / 30 / 2006-9 / 21 / 2006$ & 20.7 & $18.5-23.4$ & 2.3 & 1300 & - & 1815 & 0.0 & na & na \\
\hline & & Ma09-CO & $7 / 30 / 2006-9 / 21 / 2006$ & 23.2 & $18.4-31.7$ & 7.4 & 1130 & - & 1645 & 16.9 & 1015 & 1800 \\
\hline Windward & Wailua & Ma10-CI & $7 / 30 / 2006-9 / 21 / 2006$ & 22.5 & $20.5-25.9$ & 1.9 & 1200 & - & 1900 & 0.0 & na & na \\
\hline \multirow[t]{2}{*}{ Windward } & Wailua (Waikani) & Ma11-CI & $7 / 30 / 2006-9 / 21 / 2006$ & 22.2 & $21.0-24.0$ & 0.7 & 0700 & - & 2345 & 0.0 & na & na \\
\hline & & Ma11-CO & $7 / 30 / 2006-9 / 21 / 2006$ & 26.1 & $22.1-31.8$ & 3.3 & 1400 & - & 2045 & 29.1 & 0000 & 2345 \\
\hline \multirow[t]{2}{*}{ Windward } & Ke‘anae & Ma12-CI & $7 / 31 / 2006-9 / 21 / 2006$ & 20.0 & $19.0-21.9$ & 1.0 & 1345 & - & 2330 & 0.0 & na & na \\
\hline & & $\mathrm{Ma} 12-\mathrm{CO}$ & equipment malfunction & na & na & na & & na & & na & na & na \\
\hline
\end{tabular}




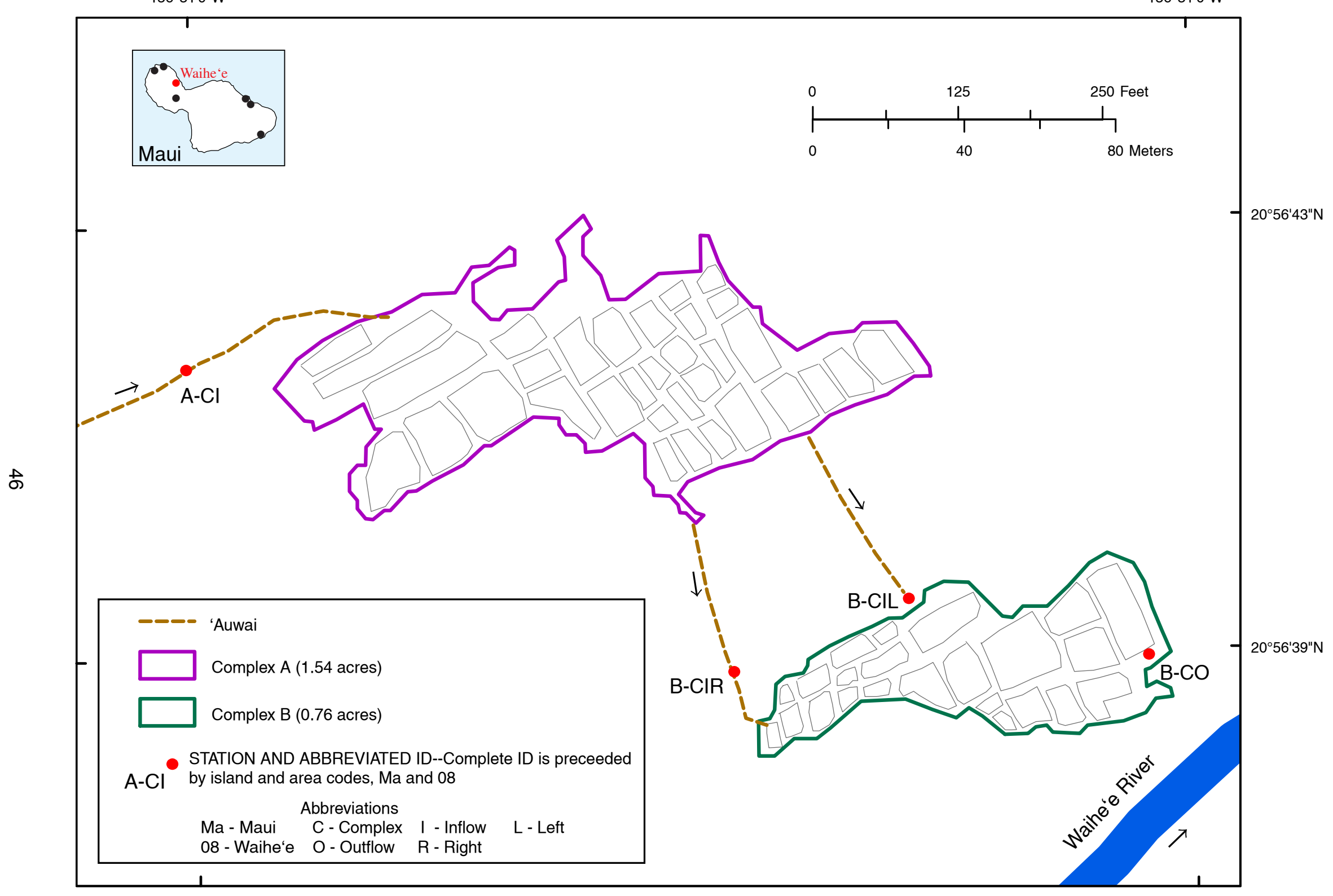

Figure 23. Waihe'e lo'i complexes, Island of Maui. 

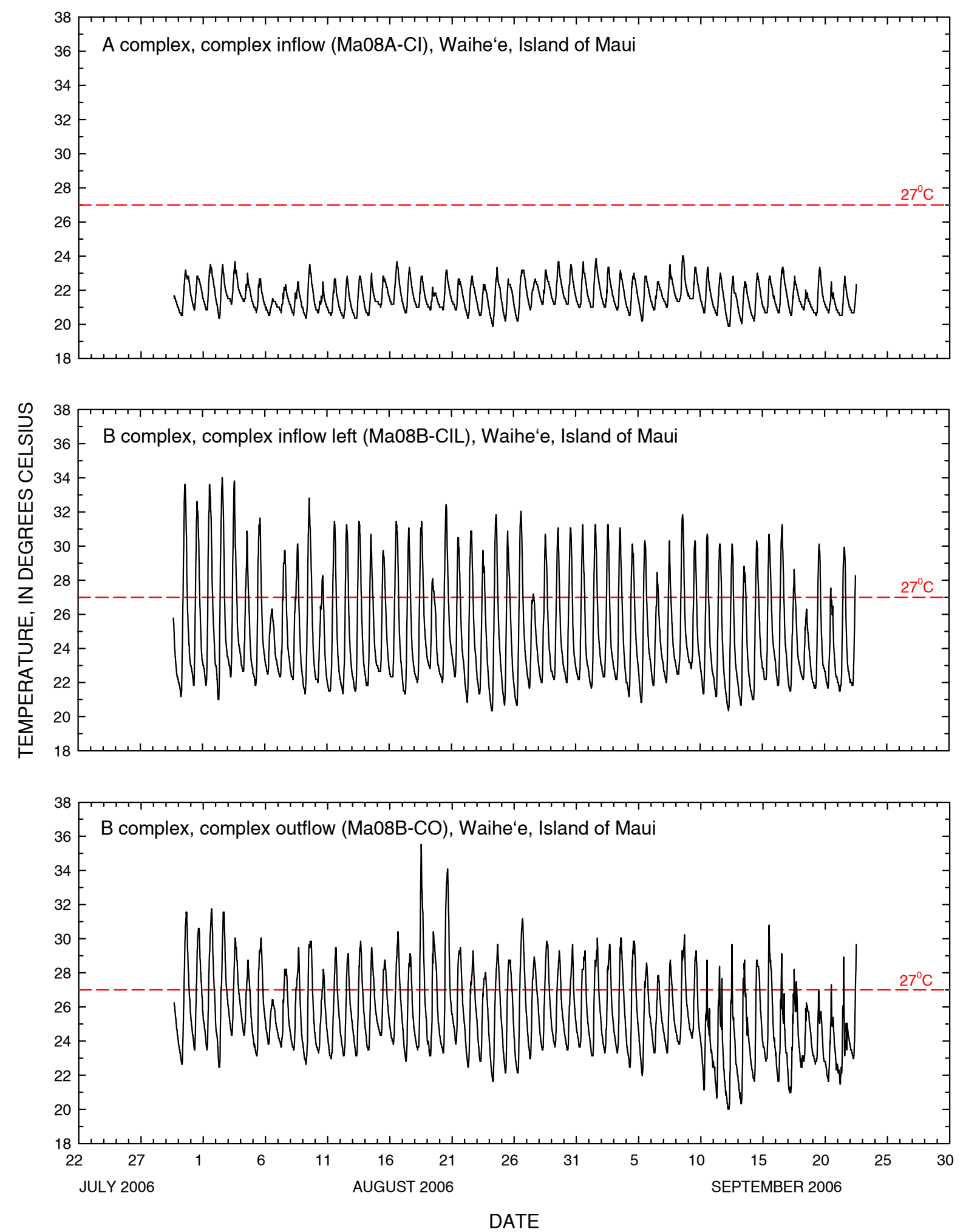

Figure 24. Water temperature in Waihe'e lo'i complexes, Island of Maui. 

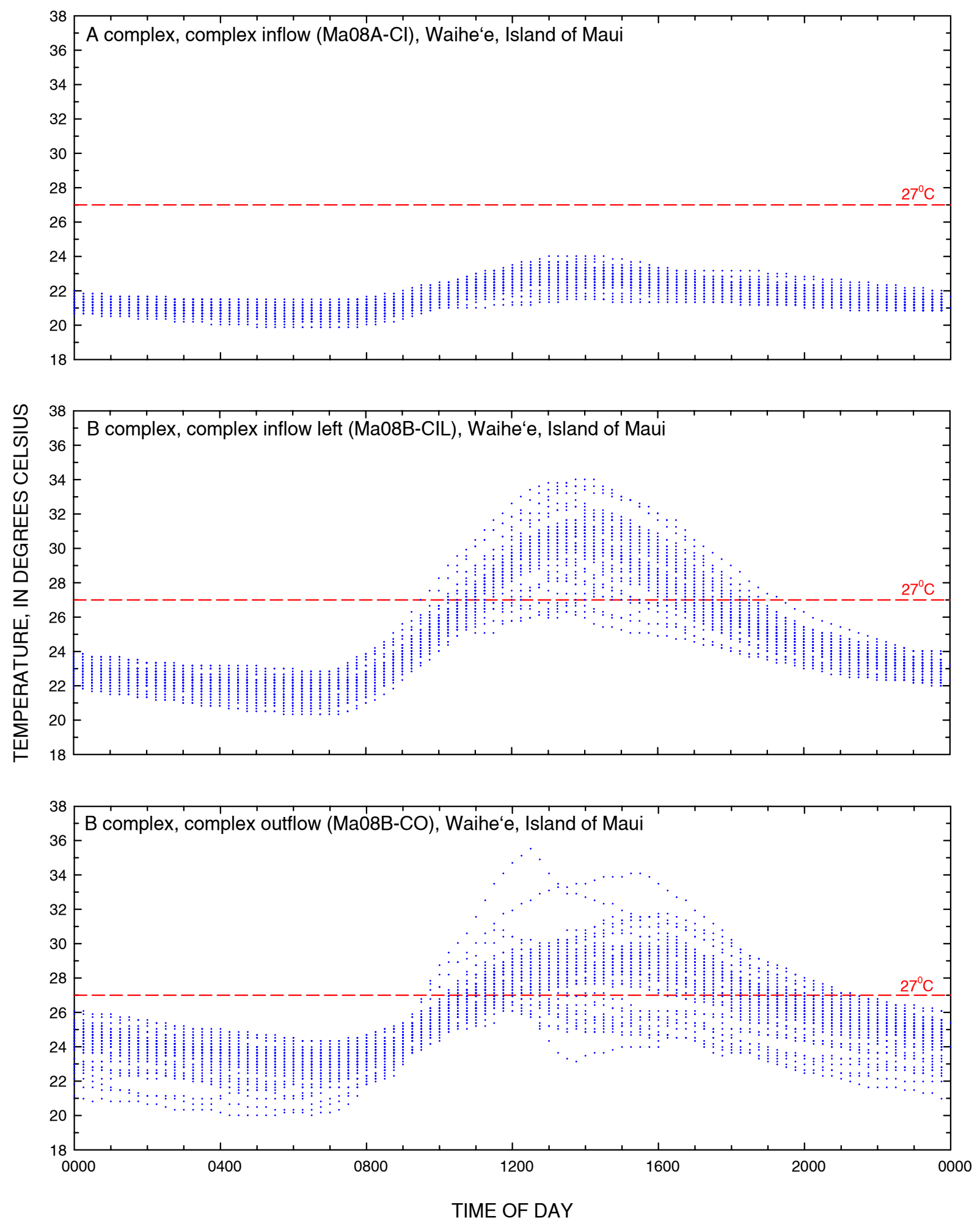

Figure 25. Daily pattern of water temperature in Waihe'e lo'i complexes, Island of Maui. Plot shows all temperature data plotted against the time of day that each measurement was recorded. 


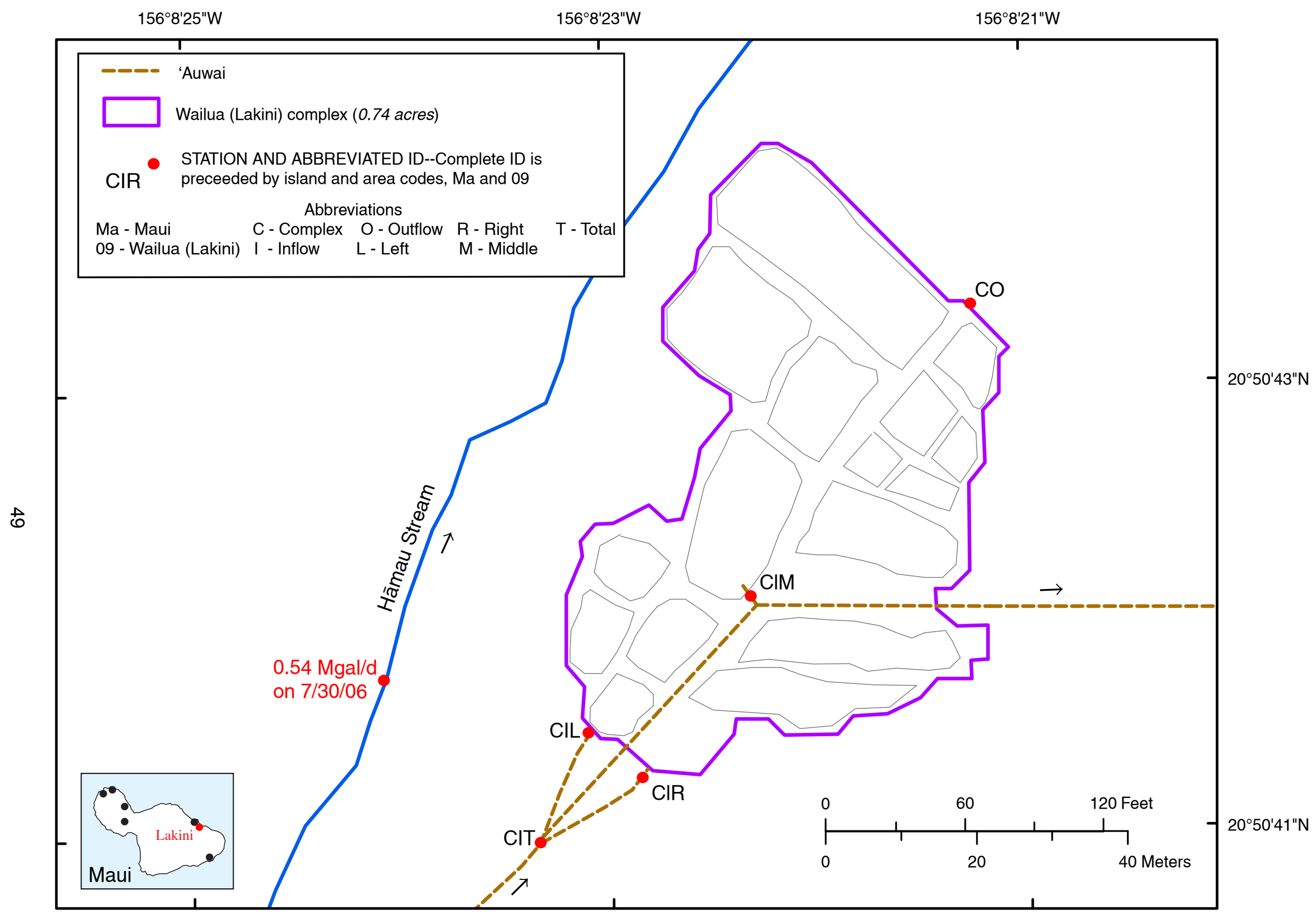

Figure 26. Wailua (Lakini) lo'i complex, Island of Maui. 


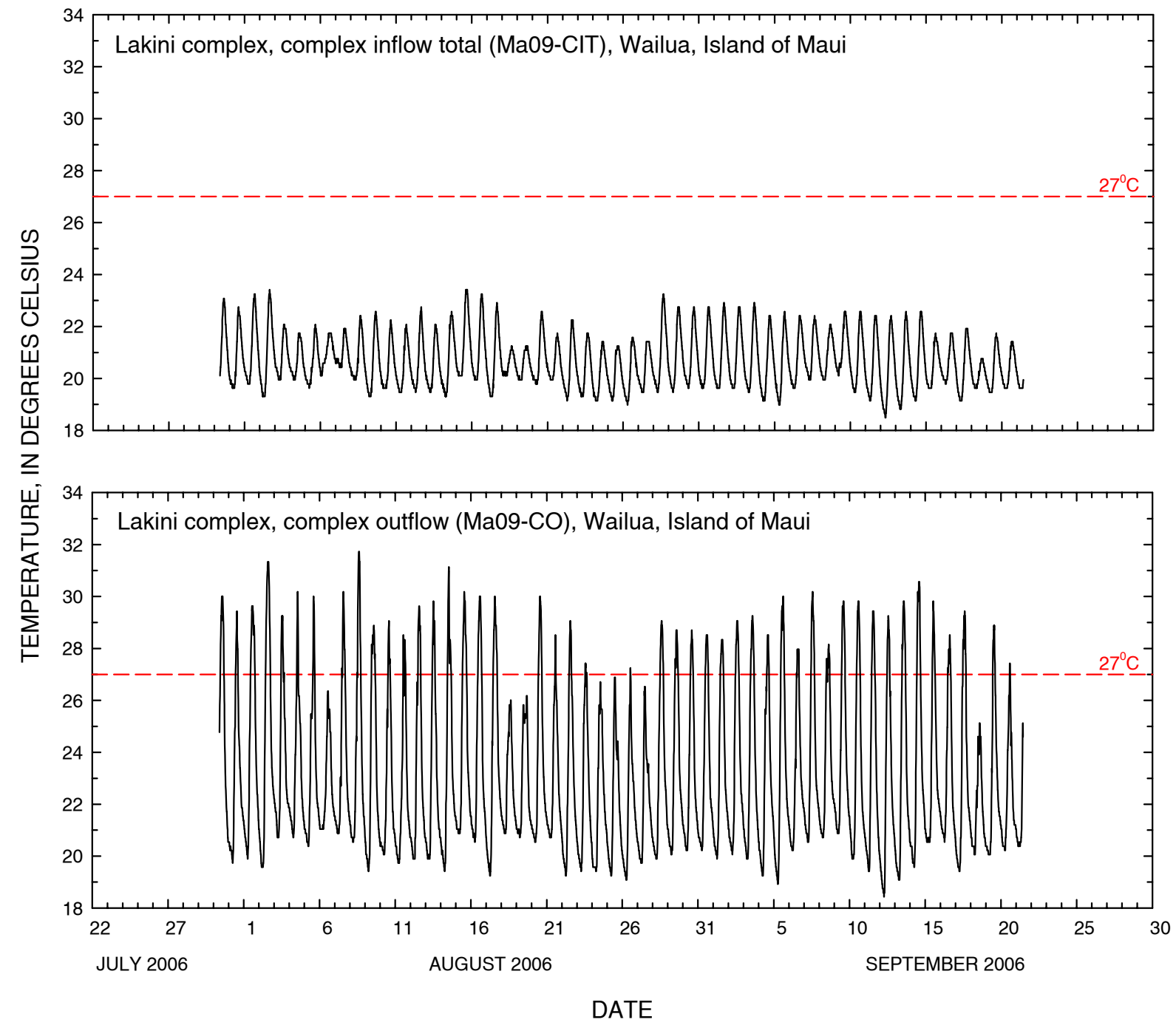

Figure 27. Water temperature in Wailua (Lakini) lo'i complex, Island of Maui. 


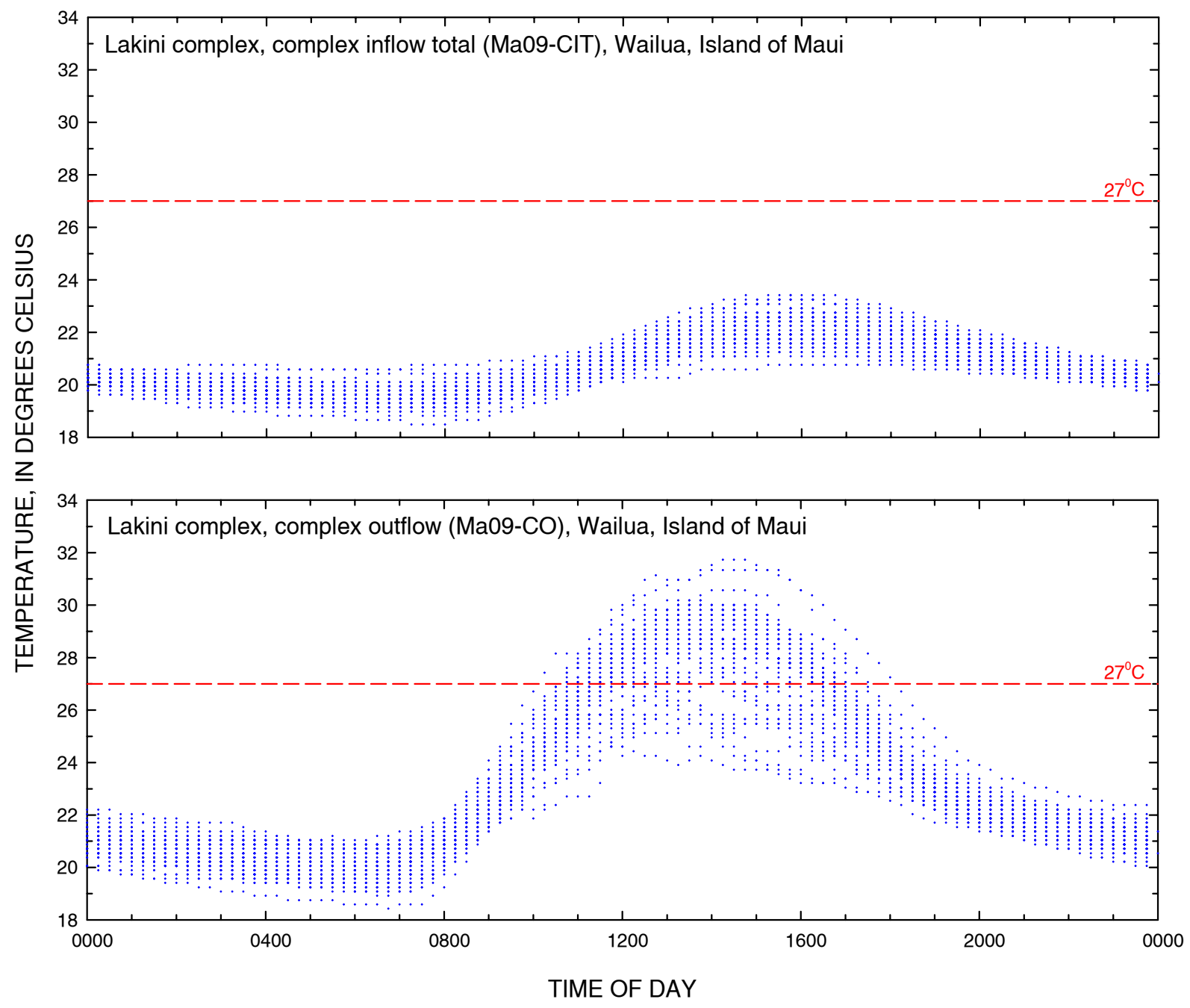

Figure 28. Daily pattern of water temperature in Wailua (Lakini) lo'i complex, Island of Maui. Plot shows all temperature data plotted against the time of day that each measurement was recorded. 


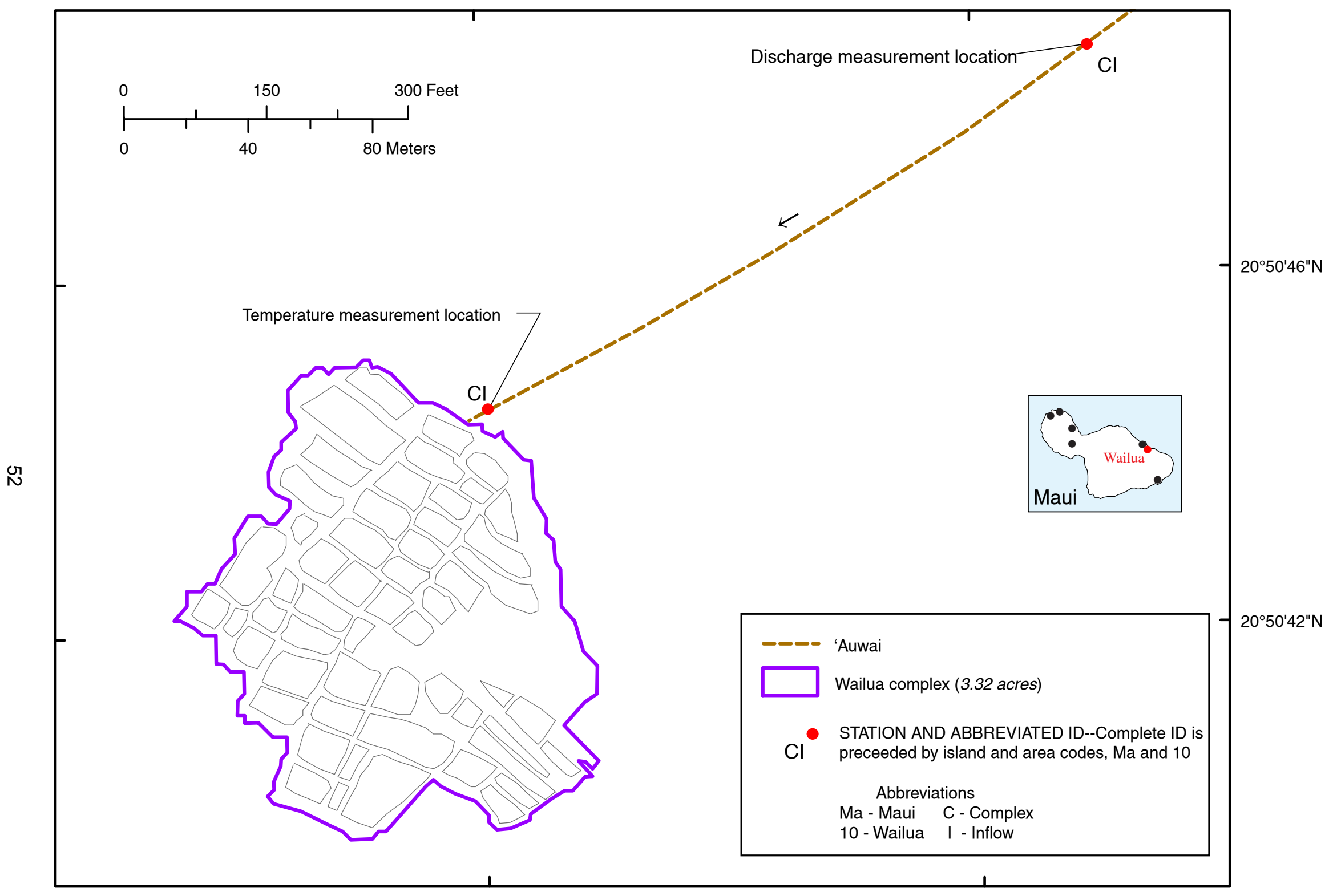

Figure 29. Wailua lo'i complex, Island of Maui. 


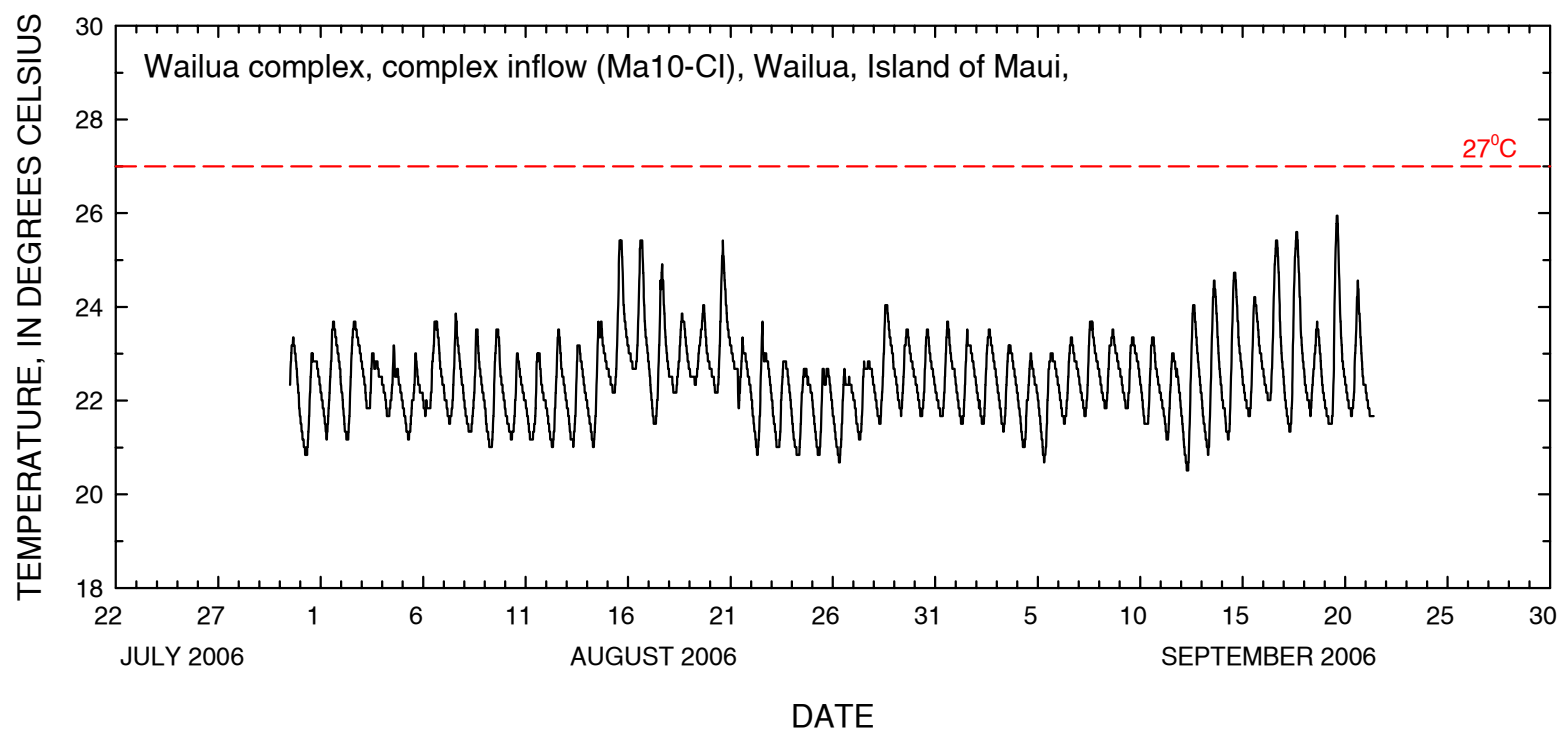

Figure 30. Water temperature in Wailua lo'i complex, Island of Maui.

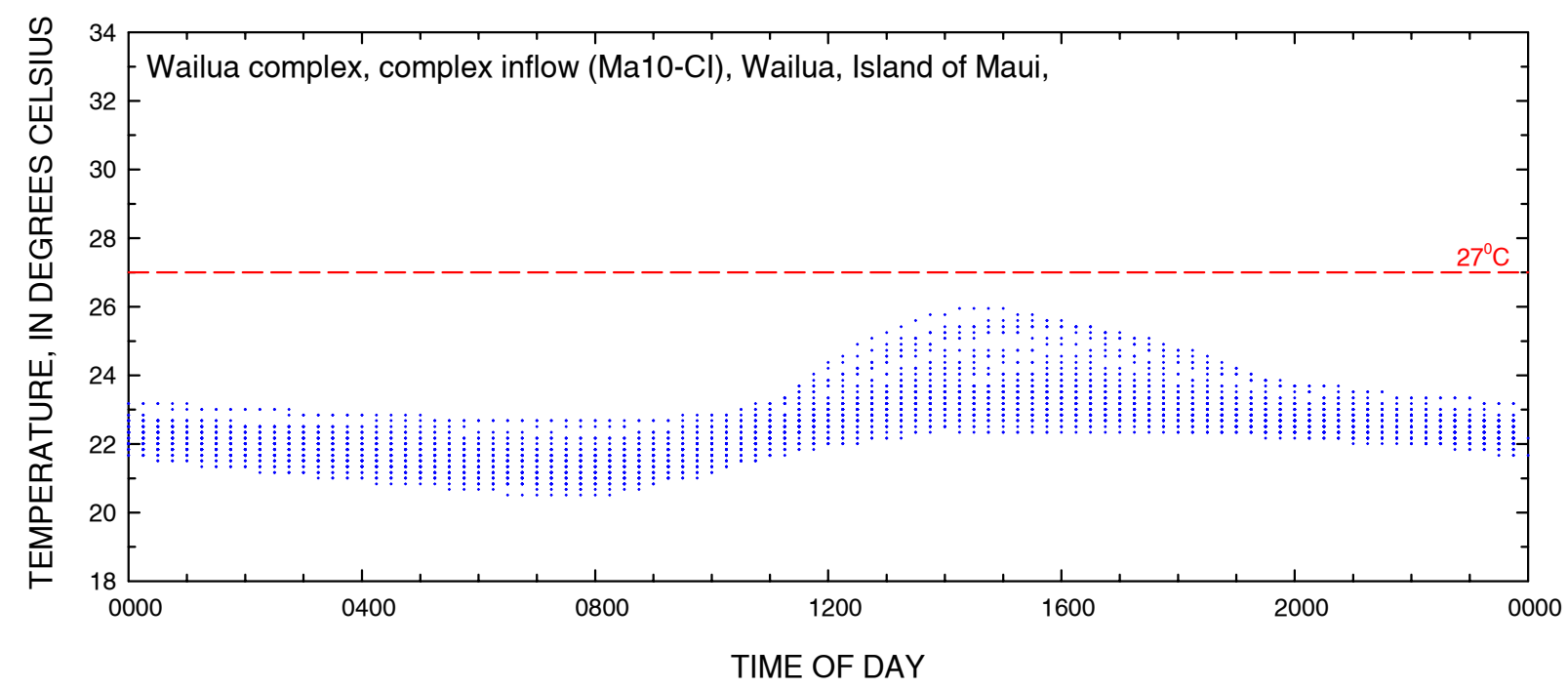

Figure 31. Daily pattern of water temperature in Wailua lo'i complex, Island of Maui. Plot shows all temperature data plotted against the time of day that each measurement was recorded. 


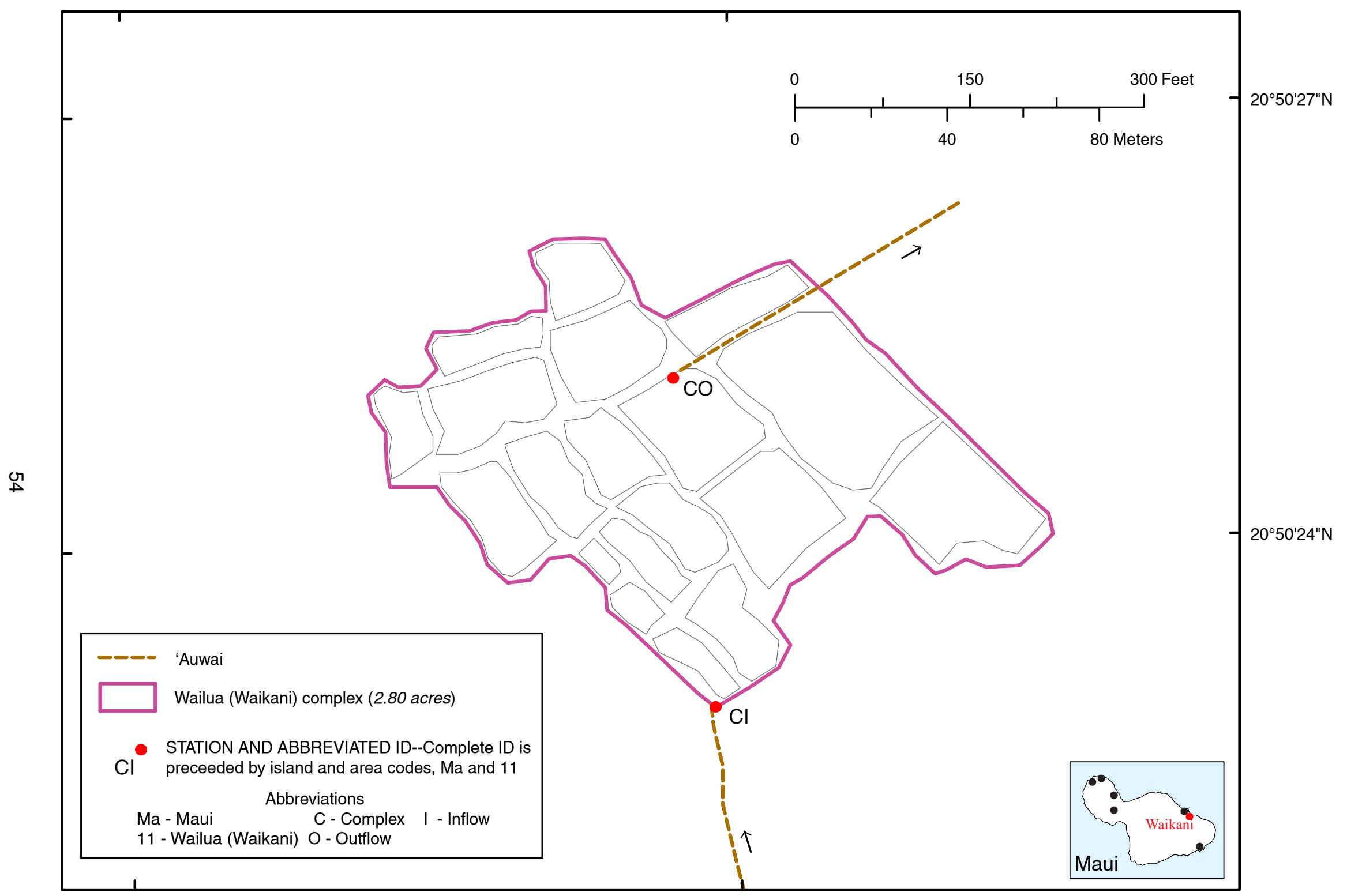

Figure 32. Wailua (Waikani) lo'i complex, Island of Maui. 


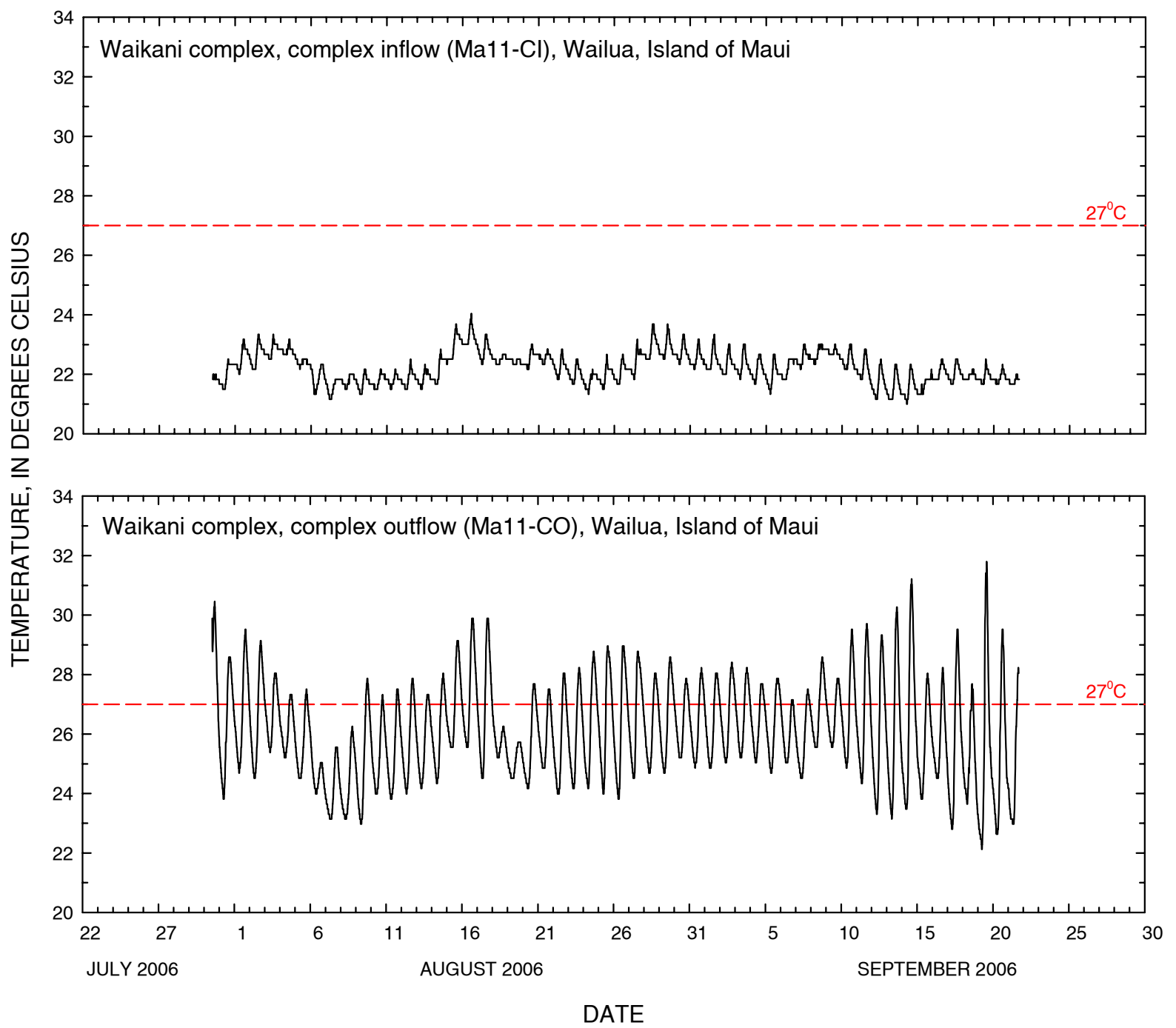

Figure 33. Water temperature in Wailua (Waikani) lo'i complex, Island of Maui. Plot shows all temperature data plotted against the time of day that each measurement was recorded. 


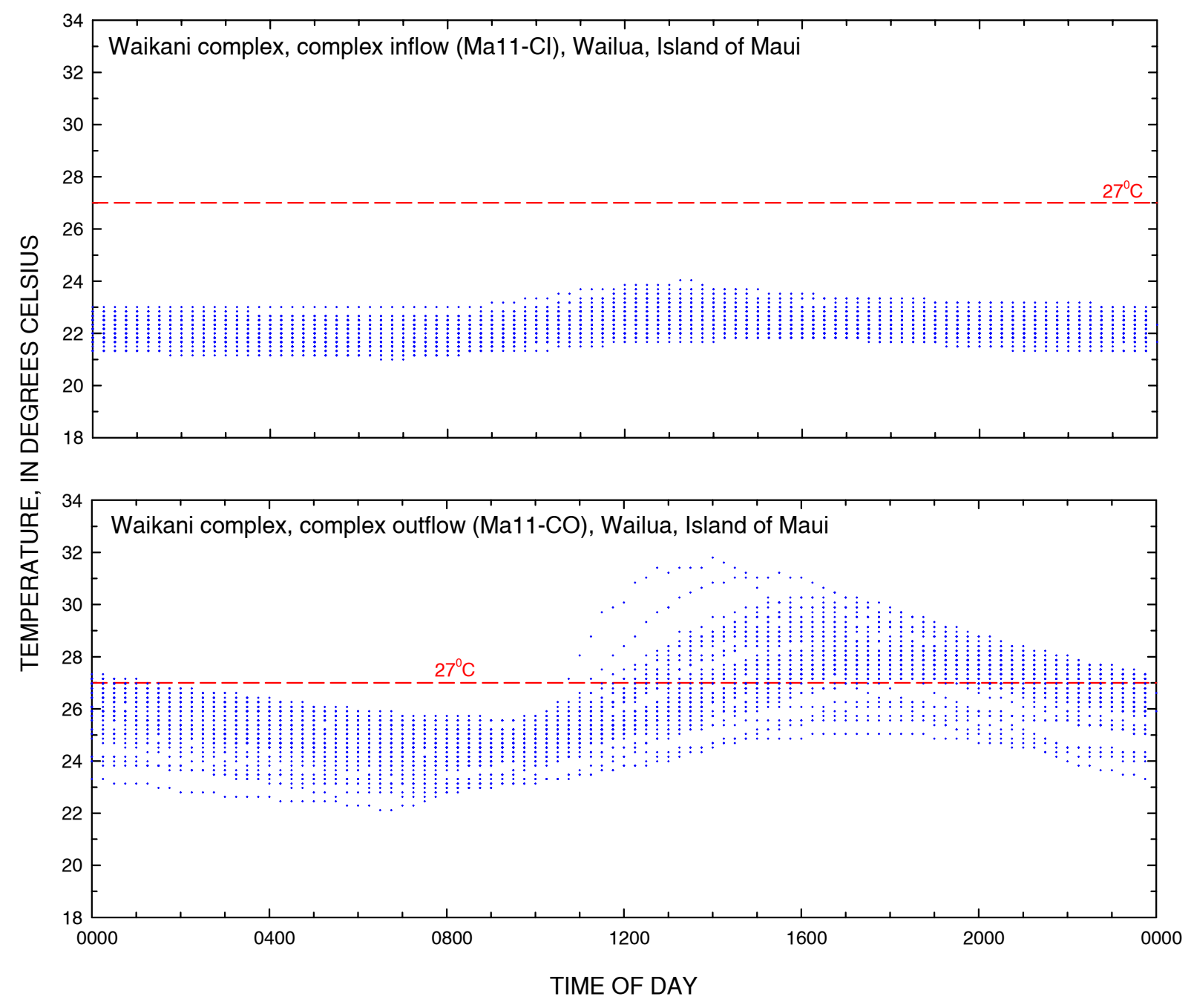

Figure 34. Daily pattern of water temperature in Wailua (Waikani) lo'i complex, Island of Maui. 


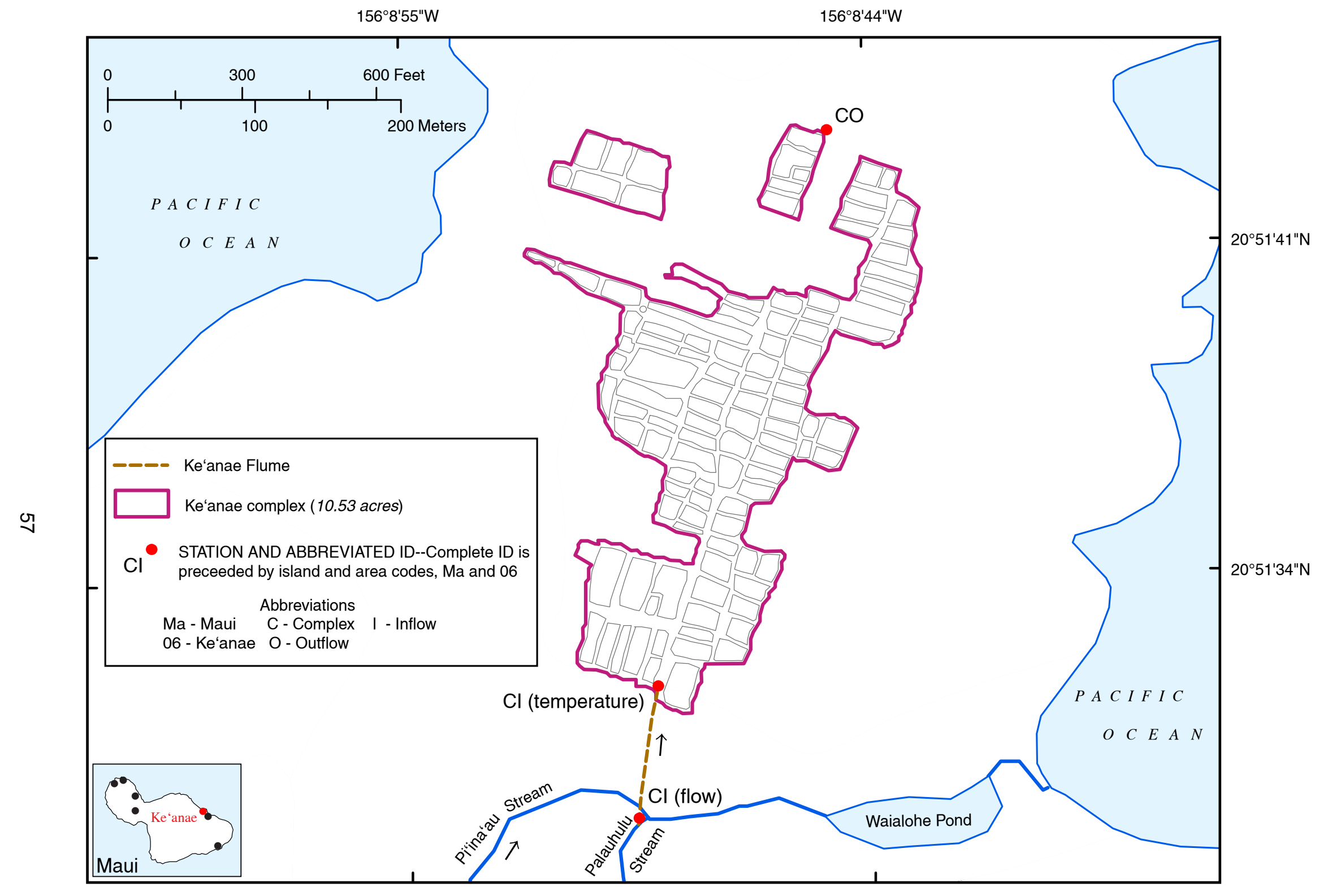

Figure 35. Ke'anae lo'i complex, Island of Maui. 


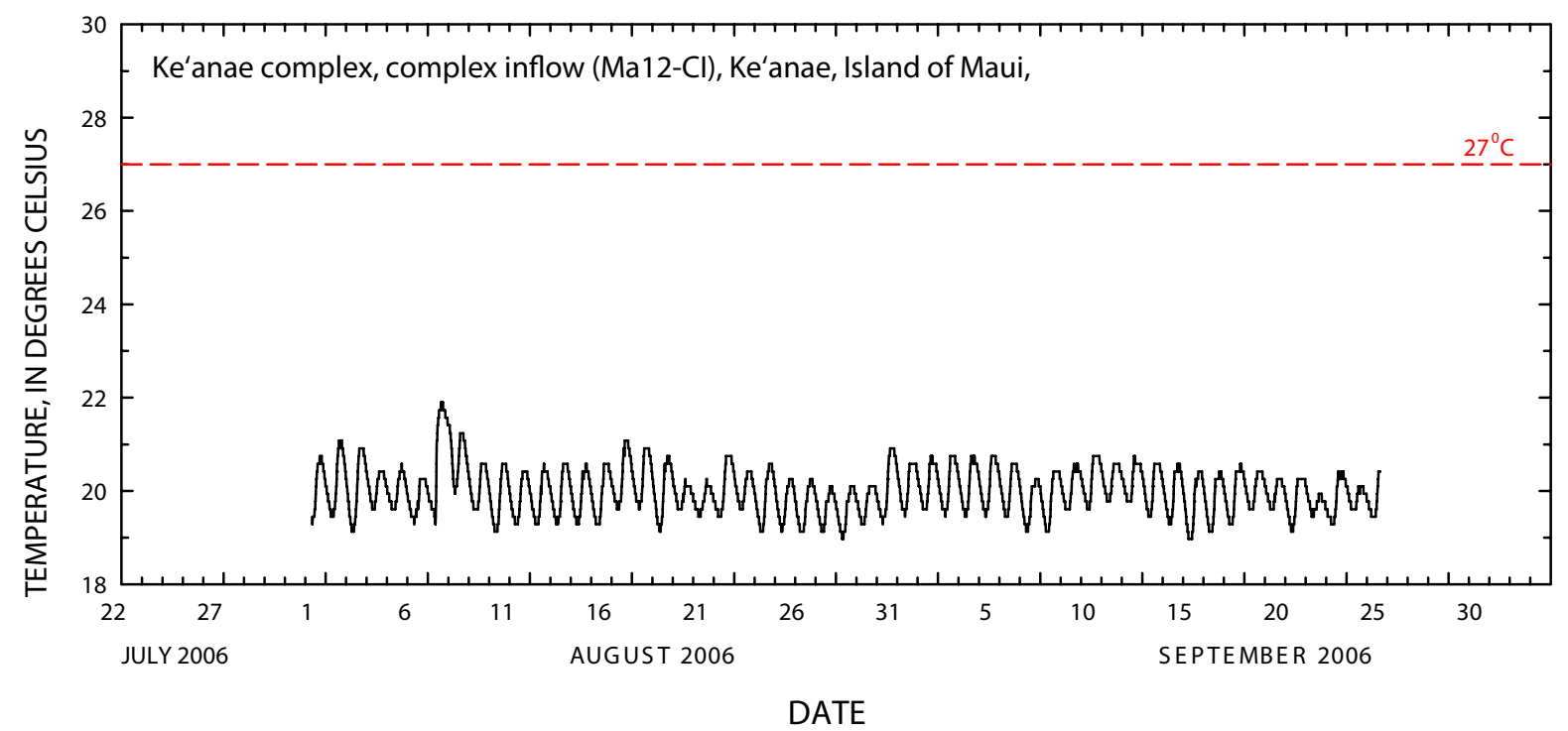

Figure 36. Water temperature in Ke'anae lo'i complex, Island of Maui.

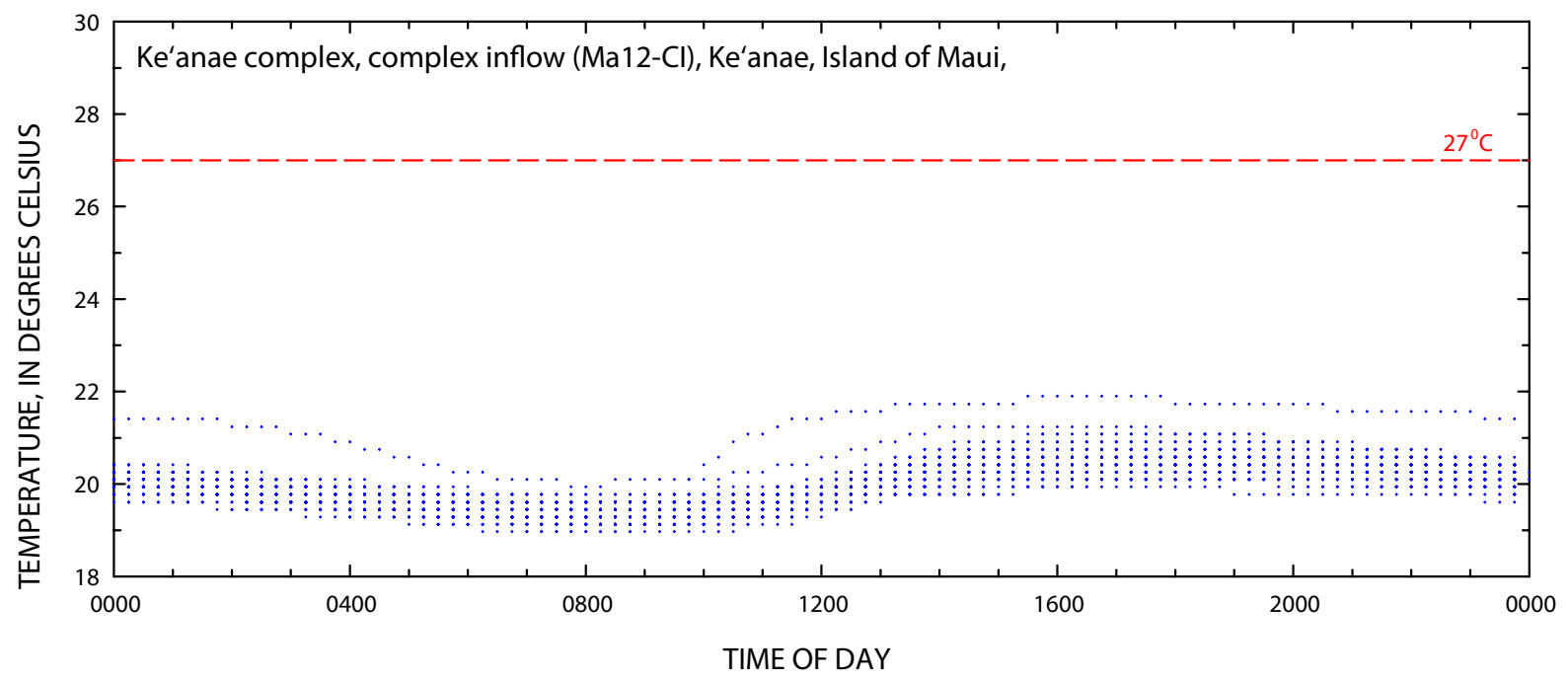

Figure 37. Daily pattern of water temperature in Ke'anae lo'i complex, Island of Maui. Plot shows all temperature data plotted against the time of day that each measurement was recorded. 


\section{Hawai'i}

On the Island of Hawai ' $i$, the windward site of Waipi 'o had two complexes available for study. Flow measurements were made on June 11, 2006, when the temperature loggers were deployed, and on August 8, 2006, when the temperature loggers were removed (tables 8 and 9). The Waipi 'o area is supplied through several 'auwai with water diverted from Wailoa Stream (figs. 37 and 38). Five flow measurements were made, and six temperature loggers were deployed at selected inflow and outflow locations (figs. 39-42).

\section{Summary}

Ten kalo cultivation areas (out of an initial count of 28 areas) were selected for study (8 windward areas, 2 leeward areas), mainly on the basis of the diversity of environmental and agricultural conditions under which wetland kalo is grown and on the basis of landowner permission and availability. Flow and water-temperature data were collected at the lo' $i$ and lo' $i$ complex level. For consistency in site selection, lo' $i$ with crops near harvesting stage were selected for the lo ' $i$ water-temperature data collection to ensure that flow and temperature data collected at different lo 'i reflect similar irrigation conditions (continuous flooding of the mature crop). Data collection was done during the dry season (June-October), when water requirements for cooling kalo are higher. Flow measurements generally were made during the warmest part of the day, and temperature measurements were made every 15 minutes at each site for about a 2-month period.

As part of this study, 62 flow measurements and 46 sets of temperature data were collected from kalo cultivation areas on four islands-Kaua' $i$, $\mathrm{O}$ 'ahu, Maui, and Hawai 'i. (the data summarized in this report are available on the World Wide Web at http://waterdata.usgs.gov/hi/nwis/sw. The average inflow for the 19 lo $i$ complexes measured in this study is $260,000 \mathrm{gad}$, and the median inflow is $150,000 \mathrm{gad}$ (table 10). The average inflow for the 17 windward sites is $270,000 \mathrm{gad}$, and the median inflow is $150,000 \mathrm{gad}$. The average inflow for the two leeward sites is $150,000 \mathrm{gad}$. The average inflow measured for 6 lo' $\mathrm{i}$ is $350,000 \mathrm{gad}$, and the median inflow is 270,000 gad. The average inflow for the 5 windward lo' $\mathrm{i}$ is $370,000 \mathrm{gad}$, and the median inflow is $320,000 \mathrm{gad}$. The inflow value for the 1 leeward lo' $\mathrm{i}$ is 210,000 gad. These values are consistent with previously reported values for inflow and are significantly higher than values generally estimated for consumption during kalo cultivation. These measurements of inflow are important for future considerations of water-use requirements for successful kalo cultivation.

Of the 17 lo' $i$ complexes where water inflow temperature was measured, only 3 lo'i complexes had inflow temperature values greater than $27^{\circ} \mathrm{C}$. These sites were Makaweli, Kaua 'i (9 percent of time), Waihe 'e, Maui (about 25 percent of time at the lower lo'i complex), and Waipi 'o, Hawai ' $i$ (about 8 percent of time at B site). The coldest mean inflow temperature was at the $\mathrm{Ke}^{\text {' }}$ anae complex $\left(20.0^{\circ} \mathrm{C}\right)$, and the warmest mean inflow temperature recorded was at the lower Waihe "e lo 'i complex $\left(24.9^{\circ} \mathrm{C}\right)$, both on Maui. The lo 'i complexes with the most stable inflow temperatures were Waihe "e

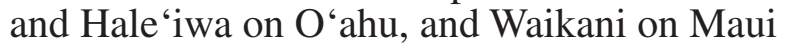
$\left(0.7^{\circ} \mathrm{C}\right.$ mean daily range). The complex with the most variable inflow temperature value was the Waihe 'e lower (B) lo' $\mathrm{i}$ complex on Maui $\left(7.6^{\circ} \mathrm{C}\right.$ mean daily range). All 15 of the sites (11 lo'i sites, 4 lo 'i complex sites) where outflow temperature was measured had some temperature values greater than $27^{\circ} \mathrm{C}$. The percentage of time that outflow temperature values exceeded $27^{\circ} \mathrm{C}$ ranged from 2.5 percent (Waiāhole lo 'i complex, O'ahu) to about 40 percent (Hanalei lo'i, Kaua'i). Mean outflow temperature values ranged from $23.0^{\circ} \mathrm{C}$ (Waiāhole lo 'i complex, $\mathrm{O}^{`} \mathrm{ahu}$ ) to $26.7^{\circ} \mathrm{C}$ (Hanalei lo ‘i, Kaua'i).

\section{References Cited}

Berg, N., McGurk, B., and Calhoun, R.S., 1997, Hydrology and land use effects in the Hanalei National Wildlife Refuge, Kaua 'i, Hawai 'i (Final Report, Interagency Agreement 14-48-000194588): Albany, California, United States Department of Agriculture Forest Service, Pacific Southwest Research Station, 62 p.

Brasher, A.M.D., Wolff, R.H., and Luton, C.D., 2004, Associations among land use, habitat characteristics, and invertebrate community structure in nine streams on the Island of O'ahu, Hawai ' $\mathrm{i}$ : U.S. Geological Survey Water-Resources Investigations Report 03-4256, 47 p.

Gingerich, S.B. and Wolff, R.H., 2005, Effects of surface-water diversions on habitat availability for native macrofauna, northeast Maui, Hawaii: U.S. Geological Survey Scientific Investigations Report 2005-5213, $93 \mathrm{p}$. 
Table 8. Summary of discharge measurements and areas for selected lo'i complexes, Island of Hawai'i.

[Mgal/d, million gallons per day; gad, gallons per acre per day; average water use is determined by summing the averages of each complex or lo'i and dividing by the number of lo' $i$ or lo' $i$ complexes ]

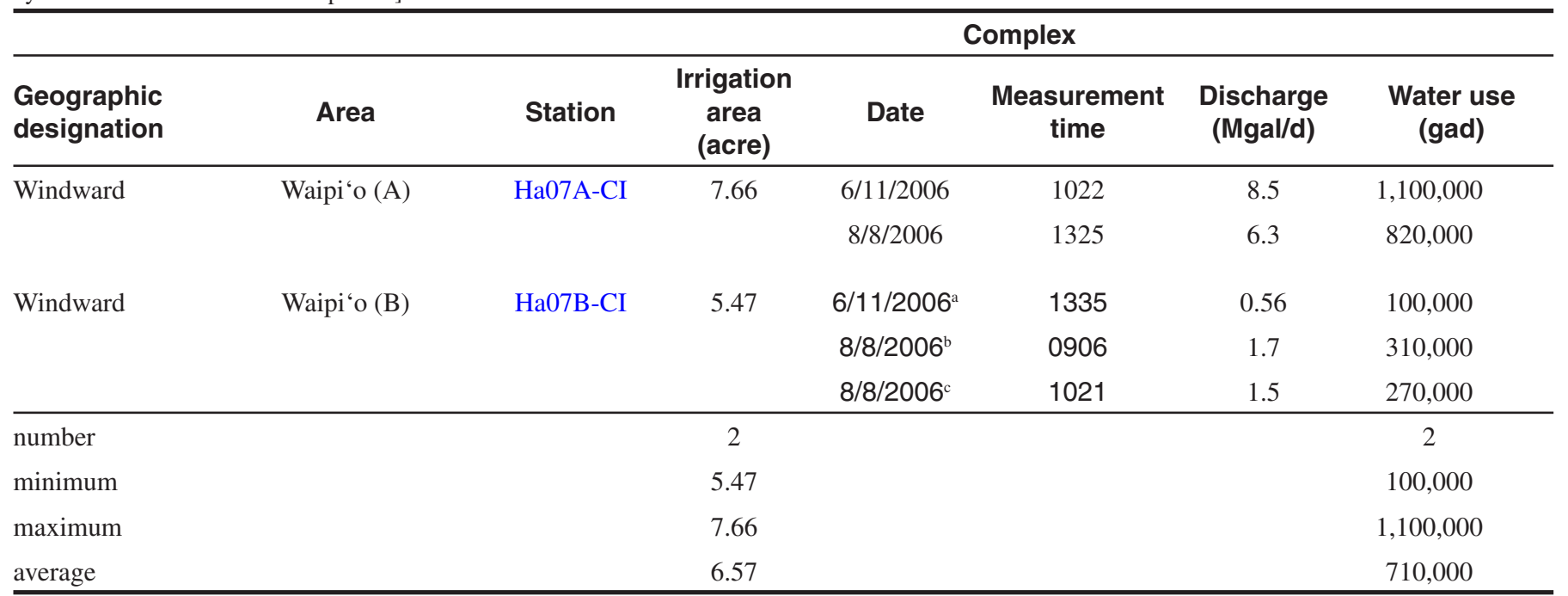

aFarmer indicated that flow was substantially less than normal because upstream diversion was damaged by recent flooding.

${ }^{b}$ Upstream diversion remained unrepaired, but the flow was increased due to rain over night.

'Second measurement.

Miles, K., 1931, Report on study of water requirements of taro in Hanapēpē Valley, cooperative study by the Territory of Hawai' $i$ and McBryde Sugar Co.: 'Ele'ele, Hawai'i, 52 p.

Oki, D.S., Wolff, R.H., and Perreault, J.A., 2006, Effects of surface-water diversion and groundwater withdrawal on streamflow and habitat, Punalu'u Stream, O'ahu, Hawai'i: U.S. Geological Survey Scientific Investigations Report 20065153, $104 p$.

Ooka, J.J., 1994, Taro diseases - A guide for field identification: Honolulu, Hawai 'i, University of Hawai'i at Mānoa, College of Tropical Agriculture and Human Resources, Hawai'i Institute of Tropical Agriculture and Human Resources Research Extension Series 148, 13 p.

Penn, D. C., 1997, Water and energy flows in Hawai 'i taro pondfields: Honolulu, Hawai 'i, University of Hawai'i at Mānoa, Ph.D. dissertation, $376 \mathrm{p}$.

Rantz, S.E., and others, 1982, Measurement and computation of streamflow-Volume 1, Measurement of stage and discharge: U.S. Geological Survey Water-Supply Paper 2175, 284 p.
Reppun v. Board of Water Supply, 1982, 65 Haw. 531, 656 P.d 57, cert. denied, 471 U.S. 014, 105 S. Ct 2016, 85 L Ed 2d 298 (1985), variously paged.

State of Hawai 'i, 2000, In re Water Use Applications, Petitions for Interim Instream Flow Standard Amendments, and Petitions for Water Reservations for the Waiāhole Ditch Combined Contested Case Hearing, 94 Hawai ‘i 97, 9 P.3d 409.

Watson, L.J., ed., 1964, Observations made with respect to irrigation and growth of taro at certain patches at Waiāhole and Kahaluu: Honolulu, Hawai'i, City \& County of Honolulu Board of Water Supply Water Resources Division in Reppun v. Board of Water Supply, variously paged.

U.S. Geological Survey, 1997 to present, National field manual for the collection of water-quality data: U.S. Geological Survey Techniques of Water-Resources Investigations, book 9, chaps. A1-A9, 2 v., variously paged. [Also available online at URL:http://pubs.water.usgs.gov/twri9A]. Chapters originally were published from 1997 to 1999; updates and revisions are ongoing and are summarized at http://water.usgs.gov/owq/FieldManual/mastererrata.html. 
Table 9. Water-temperature statistics based on measurements collected at 15-minute intervals for lo'i complexes on the Island of Hawai i $\mathrm{i}$.

$\left[{ }^{\circ} \mathrm{C}\right.$, degrees Celsius; na, not applicable]

\begin{tabular}{|c|c|c|c|c|c|c|c|c|c|c|c|c|c|c|}
\hline \multirow{3}{*}{$\begin{array}{l}\text { Geographic } \\
\text { designation }\end{array}$} & \multirow{3}{*}{$\begin{array}{c}\text { Area } \\
\text { Waipi`o (A) }\end{array}$} & \multirow{3}{*}{$\begin{array}{l}\text { Station } \\
\mathrm{Ha} 07 \mathrm{~A}-\mathrm{CI}\end{array}$} & \multirow{2}{*}{\multicolumn{3}{|c|}{ Period of record }} & \multicolumn{3}{|c|}{ Temperature $\left({ }^{\circ} \mathrm{C}\right)$} & \multirow{2}{*}{\multicolumn{3}{|c|}{$\begin{array}{c}\text { Range of times daily } \\
\text { - peak temperatures } \\
\text { occurred }\end{array}$}} & \multicolumn{3}{|c|}{$\begin{array}{c}\text { Temperature measurements } \\
\text { greater than } 27^{\circ} \mathrm{C}\end{array}$} \\
\hline & & & & & & \multirow{2}{*}{$\begin{array}{c}\text { Mean } \\
21.4\end{array}$} & \multirow{2}{*}{$\frac{\text { Range }}{19.3-24.8}$} & \multirow{2}{*}{$\begin{array}{c}\begin{array}{c}\text { Mean daily } \\
\text { range }\end{array} \\
1.6\end{array}$} & & & & \multirow{2}{*}{$\begin{array}{c}\text { Percent } \\
0.0\end{array}$} & \multirow{2}{*}{$\begin{array}{c}\begin{array}{c}\text { Earliest time } \\
\text { of day }\end{array} \\
\text { na }\end{array}$} & \multirow{2}{*}{$\begin{array}{c}\begin{array}{c}\text { Latest time } \\
\text { of day }\end{array} \\
\text { na }\end{array}$} \\
\hline & & & $6 / 11 / 2006$ & - & $8 / 8 / 2006$ & & & & 1000 & - & 2200 & & & \\
\hline & & Ha07A-LI & $6 / 11 / 2006$ & - & $8 / 8 / 2006$ & 21.8 & $19.4-28.6$ & 3.0 & 0900 & - & 2015 & 0.4 & 1230 & 1515 \\
\hline & & Ha07A-LO & $6 / 11 / 2006$ & - & 8/8/2006 & 23.8 & $20.8-29.8$ & 3.9 & 1030 & - & 1800 & 5.3 & 1115 & 1900 \\
\hline \multirow[t]{3}{*}{ Windward } & Waipi`o (B) & Ha07B-CI & $6 / 11 / 2006$ & - & $8 / 2 / 2006$ & 23.4 & $19.8-31.2$ & 5.4 & 1030 & - & 1715 & 7.7 & 1045 & 1845 \\
\hline & & Ha07B-LI & $6 / 11 / 2006$ & - & $8 / 2 / 2006$ & 24.3 & $20.3-36.2$ & 7.1 & 1000 & - & 1700 & 15.7 & 1000 & 2100 \\
\hline & & Ha07B-LO & $6 / 11 / 2006$ & - & $8 / 2 / 2006$ & 25.6 & $21.1-38.1$ & 8.6 & 1030 & - & 1630 & 21.7 & 0930 & 2145 \\
\hline
\end{tabular}




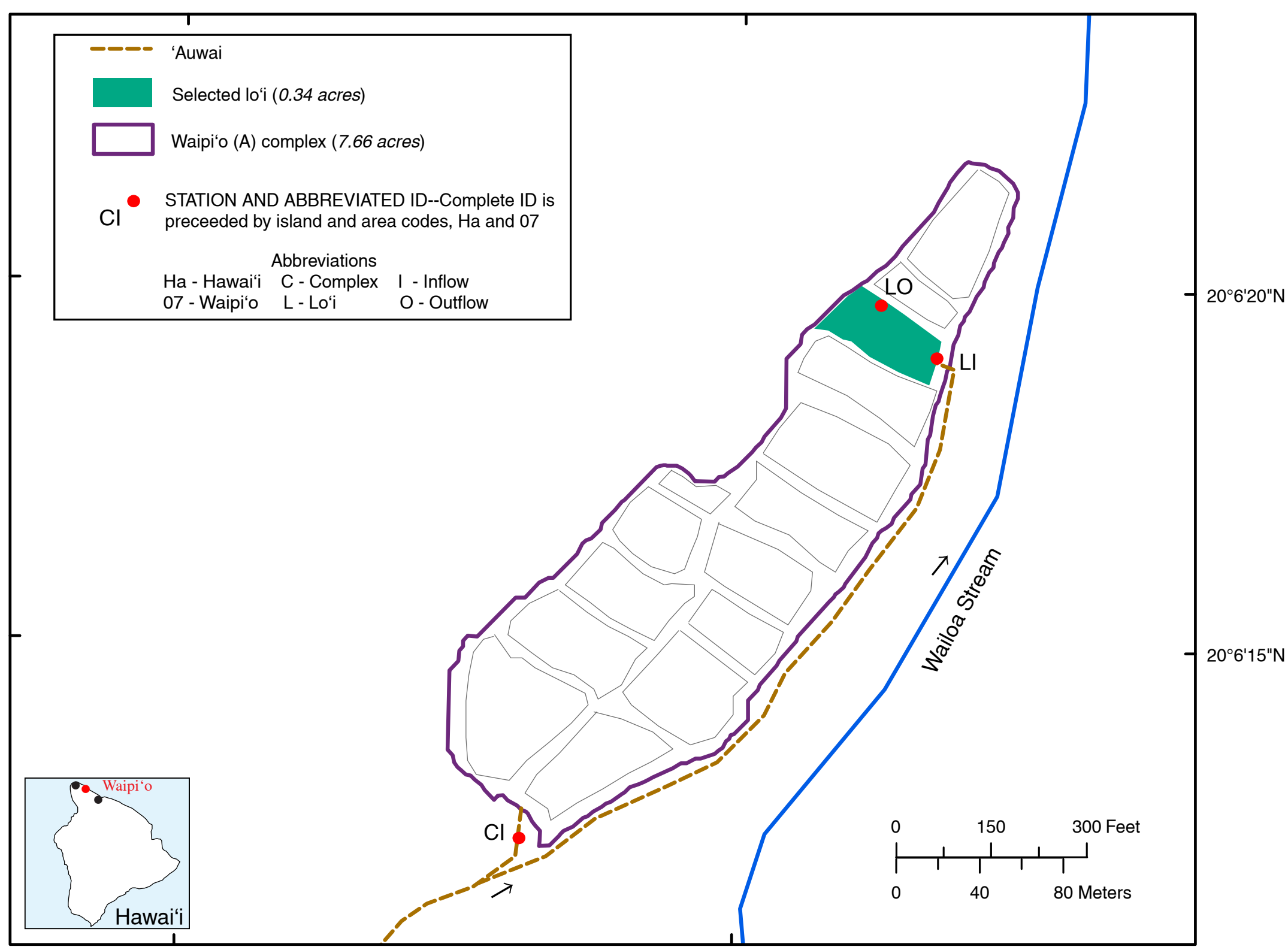

Figure 38. Waipi'o (A) lo'i complex, Island of Hawai'i. 


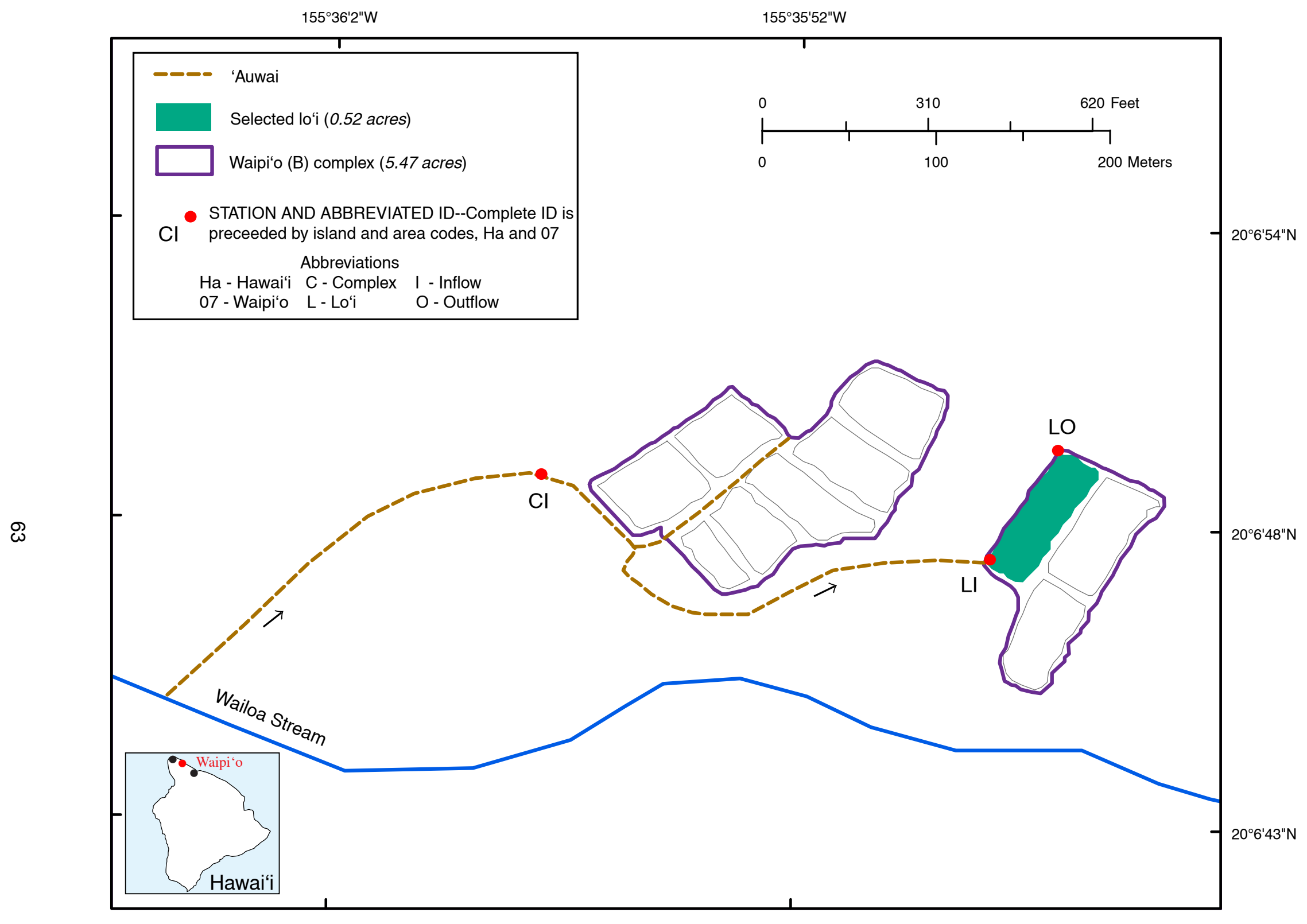

Figure 39. Waipi'o (B) lo'i complex, Island of Hawai'i. 

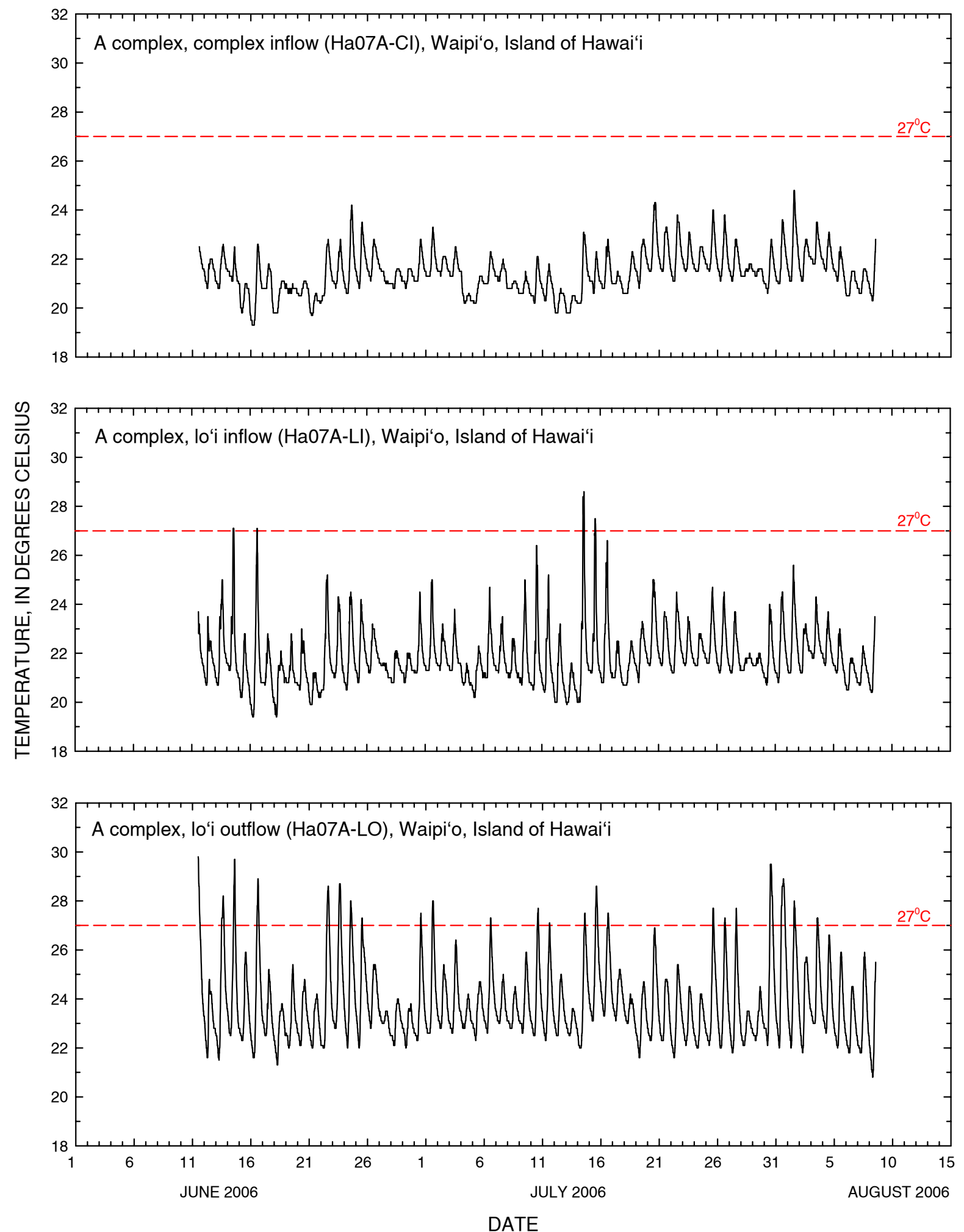

Figure 40. Water temperature in Waipi'o (A) lo'i complex, Island of Hawai'i. 

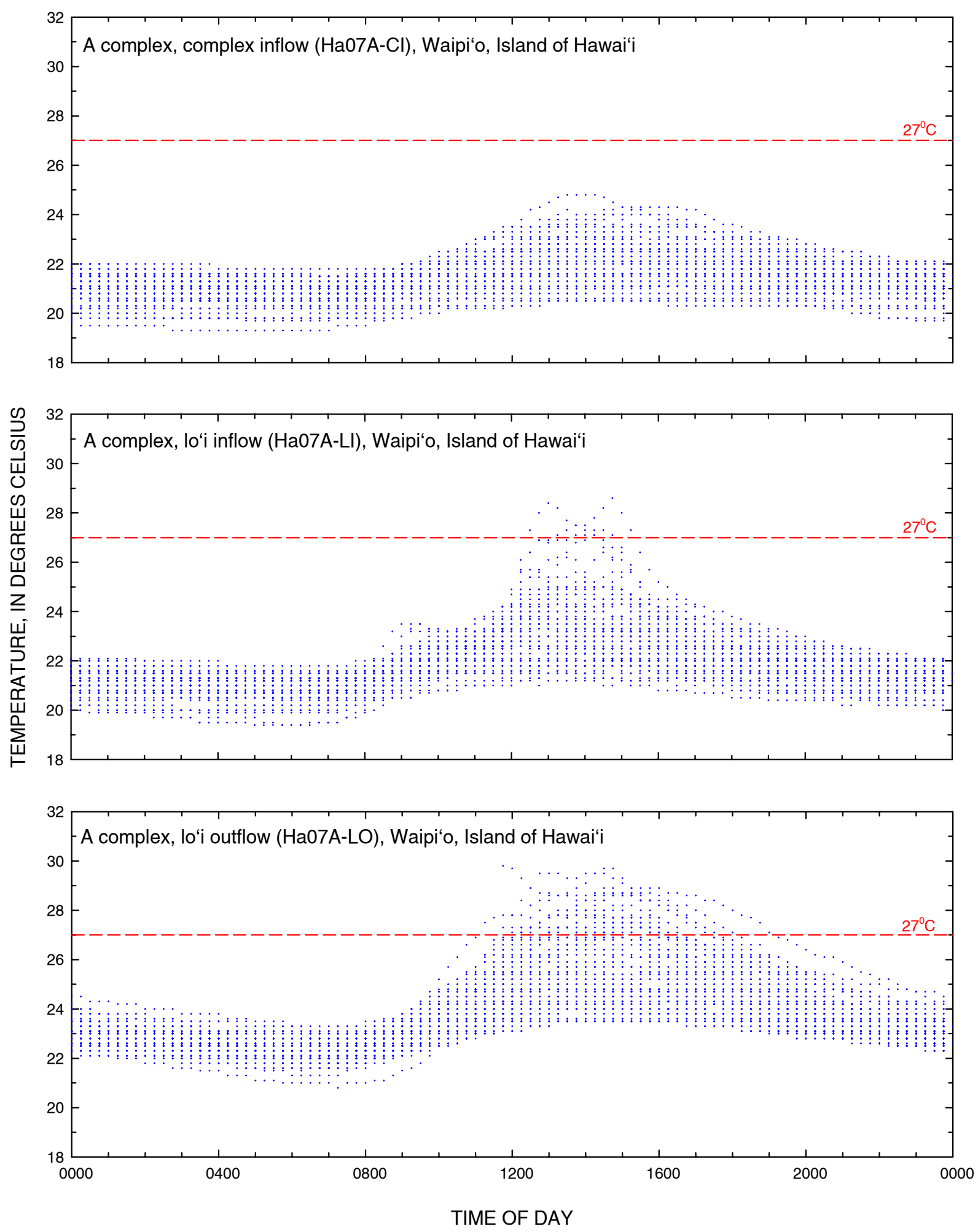

Figure 41. Daily pattern of water temperature in Waipi'o (A) lo'i complex, Island of Hawai'i. Plot shows all temperature data plotted against the time of day that each measurement was recorded. 

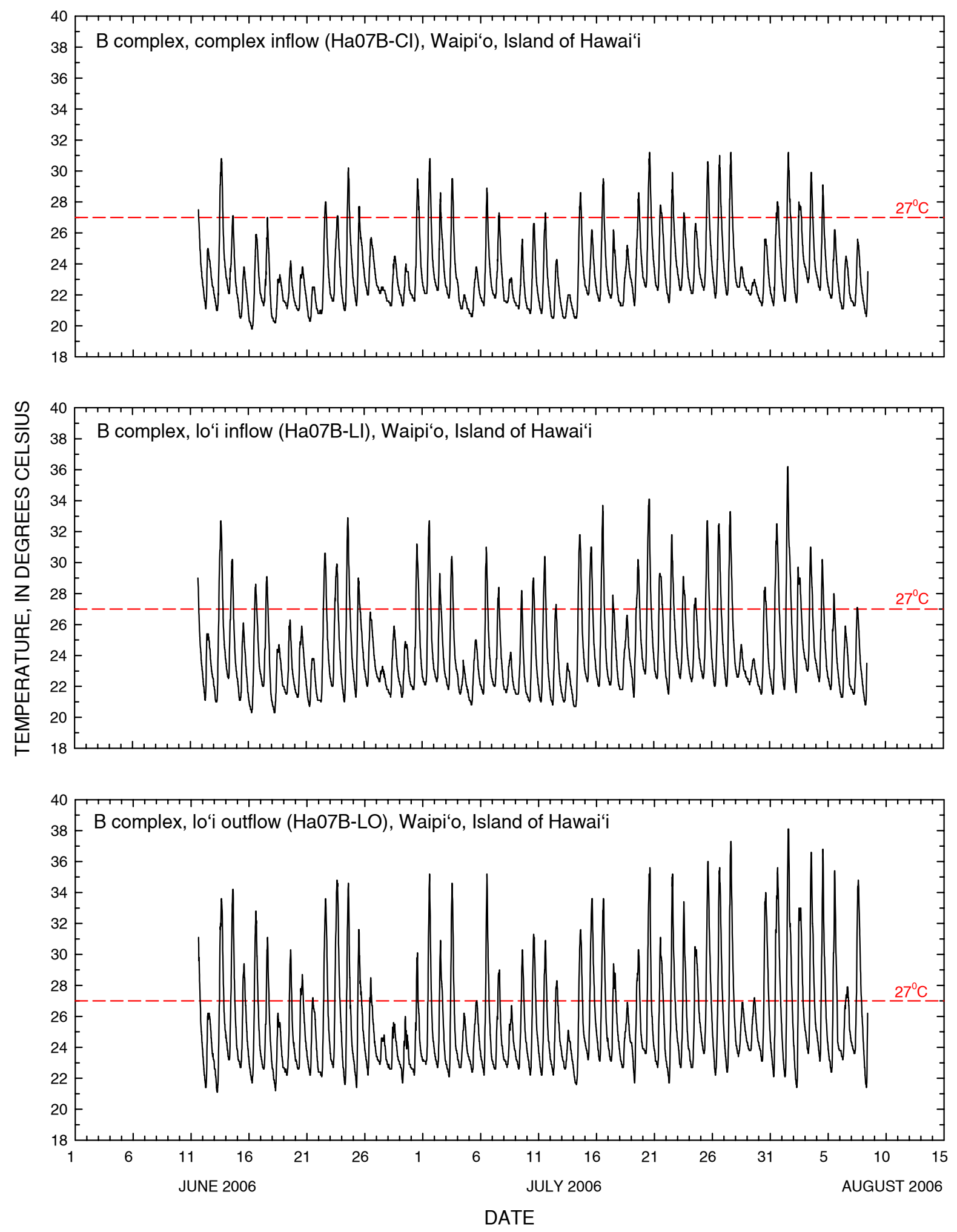

Figure 42. Water temperature in Waipi'o (B) lo'i complex, Island of Hawai'i. 

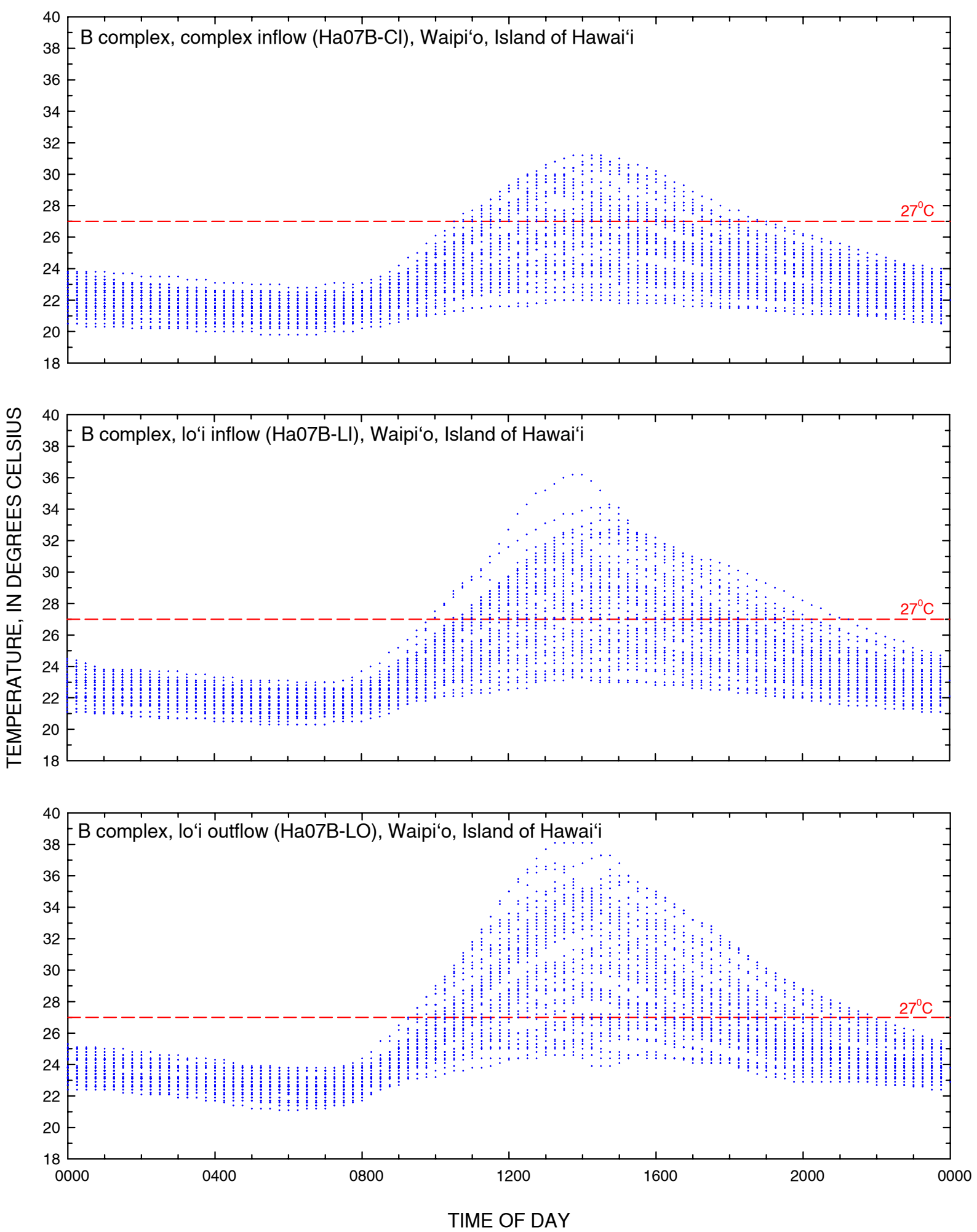

Figure 43. Daily pattern of water temperature in Waipi'o (B) lo'i complex, Island of Hawai'i. Plot shows all temperature data plotted against the time of day that each measurement was recorded. 
Table 10. Summary of water use calculated for lo' $i$ and lo' $i$ complexes by island, State of Hawai' $i$.

[gad, gallons per acre day; na, not available]

\begin{tabular}{|c|c|c|c|c|c|c|c|c|}
\hline \multirow[b]{2}{*}{ Island } & \multicolumn{4}{|c|}{ Complex } & \multicolumn{4}{|c|}{ Lo‘i } \\
\hline & Number & $\begin{array}{c}\text { Average } \\
\text { water use } \\
\text { (gad) }\end{array}$ & $\begin{array}{c}\text { Average } \\
\text { windward } \\
\text { water use } \\
\text { (gad) }\end{array}$ & $\begin{array}{c}\text { Average } \\
\text { leeward } \\
\text { water use } \\
\text { (gad) }\end{array}$ & Number & $\begin{array}{c}\text { Average } \\
\text { water use } \\
\text { (gad) }\end{array}$ & $\begin{array}{c}\text { Average } \\
\text { windward } \\
\text { water use } \\
\text { (gad) }\end{array}$ & $\begin{array}{c}\text { Average } \\
\text { leeward } \\
\text { water use } \\
\text { (gad) } \\
\end{array}$ \\
\hline Kaua‘i & 6 & 120,000 & 97,000 & 260,000 & 2 & 220,000 & 220,000 & na \\
\hline O'ahu & 5 & 310,000 & 380,000 & 44,000 & 4 & 400,000 & 460,000 & 210,000 \\
\hline Hawai'i & 2 & 710,000 & 710,000 & na & na & na & na & na \\
\hline $\begin{array}{l}\text { Average of all } \\
\text { measurements }\end{array}$ & & 260,000 & 270,000 & 150,000 & & 350,000 & 370,000 & 210,000 \\
\hline
\end{tabular}


This page intentionally left blank 


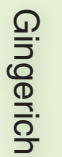

ํํㄹ

Ф 